\title{
Problematic Course Supervision within Turkish Education System
}

\author{
Akif KÖSE ${ }^{\mathrm{a}^{*}}$ \\ ${ }^{a}$ Kahramanmaraş Sütçü İmam Üniversitesi, Eğitim Fakültesi \\ Kahramanmaraş/Türkiye

\section{Article Info}

DOI: $10.14812 /$ cuefd. 304234

Keywords:

Supervision,

Course Supervision,

Teacher Opinions,

School Administrator Opinions,

Inspector Opinions.

\begin{abstract}
This research aims to reveal the views of teachers, school administrators and inspectors on the necessity of course supervision and, if necessary, by whom they are conducted. Having a qualitative research design, data were obtained through interviews. The research sample consisted of ten teachers and ten school administrators working at state schools affiliated with the Kahramanmaras Provincial Directorate of National Education and ten inspectors working in Kahramanmaras Provincial Directorate of National Education. A semi-structured interview form was used during the interviews. Content analysis method was used to determine the conceptualization of the data obtained as a result of the interviews and to organize them in a logical way. Analyses have revealed that course supervision should be done, and it requires expertise; moreover the participants were of the view that school administrators are not experts in course supervision and that course supervision should be done by inspectors. In addition, some positive and negative aspects exist in course supervision performed by school administrators and inspectors, and the negative aspects of course supervision by the inspectors mostly derive from system. Various recommendations have been provided. Supervisors may be trained with inservice training and courses in terms of supervision; supervisory competencies may be taken into account in the selection of school administrators; school inspectors may take active roles in supervision work and school administrators can work in coordination with inspectors during supervision process. The survey also recommends that the Ministry of National Education be able to put in place an audit that is appropriate to the Turkish education system in line with the views of all stakeholders.
\end{abstract}

\section{Türk Eğitim Sisteminde Ders Denetimi Sorunsalı}

\section{Makale Bilgisi}

DOI: $10.14812 /$ cuefd. 304234

Anahtar Kelimeler:

Denetim,

Ders Denetimi,

Öğretmen Görüşleri,

Okul Müdürü Görüşleri,

Maarif Müfettişi Görüşleri.

\section{Öz}

Bu araştırmada ders denetiminin gerekliliğine, ders denetiminin okul müdürleri ya da müfettişler tarafından yapılmasının olumlu ve olumsuz yönlerine ve ders denetimlerinin kimler tarafından yapılması gerektiğine ilişkin öğretmen, okul müdürü ve maarif müfettişlerinin görüşlerinin incelenmesi amaçlanmıştır. Araştırma nitel bir çalışma olup veriler görüşme yolu ile elde edilmiştir. Kahramanmaraş ili merkezinde görevli 10 öğretmen ve 10 okul idarecisi ile Kahramanmaraş il Millî Eğitim Müdürlüğü’nde görevli 10 maarif müfettişi örneklem olarak belirlenmiştir. Araştırmacı tarafından hazırlanan yarı yapılandırılmış görüşme formu kullanılarak katılımcılar ile görüşmeler yapılmış, elde edilen veriler içerik analizine tabi tutulmuştur. Araştırma sonucunda ders denetimlerinin yapılması gerektiği, ders denetiminin uzmanlık gerektirdiği, katılımcıların okul müdürlerinin ders denetiminde uzman olmadıklarını ve ders denetimlerinin müfettişler tarafından yapılması gerektiğini düşündükleri ortaya

akifkose@ksu.edu.tr 


\begin{abstract}
çıkmıştır. Ayrıca müfettiş veya okul müdürünün ders denetimi yapmalarında birtakım olumlu ve olumsuz yönlerin bir arada bulunduğu, ders denetimlerinin müfettişler tarafından yapılmasının olumsuz yönlerinin çoğunlukla sistem kaynaklı olduğu sonuçları da ortaya çıkmıştır. Araştırmada, denetim elemanlarının denetim alanında hizmet içi eğitim ve kurslarla eğitilebilecekleri, okul müdürlerinin seçiminde denetim yeterliklerinin de dikkate alınabileceği, müfettişlerin denetim çalışmalarında etkin görev alabilecekleri ve okul müdürlerinin denetim sürecinde müfettişlerle eşgüdümlü olarak çalışabilecekleri, denetim periyotlarının arttırılarak denetimin sürece yayılabileceği, Millî Eğitim Bakanlığınca paydaşların tamamından alınacak görüşler doğrultusunda Türk eğitim sistemine uygun bir denetim uygulaması ortaya konulabileceği önerileri getirilmiştir.
\end{abstract}

\title{
Introduction
}

Educational systems are the systems in which human factor is mostly involved as they perform production for people and with people. Their most significant inputs are humans, and their products are behaviors that are desired. In this sense, it is not possible to ruminate about education systems separately from humans. It may be stated that the history of education has started with the history of mankind, has developed in parallel with the development of human history, and has concurrently developed this history. Upon examining the development of education whose history is as old as human history, the institutionalization of education started after the second half of the 18th century. When this continuing process of institutionalization has been observed day by day, the presence of a constant change which is a process that will exist with the presence of humans and education is pretty much striking.

In the course of institutionalization of education, supervision has always seemed to exist alongside education. Taking the history of Turkish education into consideration, the first step towards the establishment of the maarif organization was in 1846 after the establishment of the Mekatib-i Umumiye Nezaretin in 1847 the "Instruction to Be Achieved by Primary School Teachers" (Buluç, 1997). The concepts of inspectors and inspection were included for the first time in 1862, and in the Ministry of Education dated 1869, supervision duties were among the official duties of the education organization. A guideline published in 1914 set out the guidelines for the inspection of the state and private schools. During the Republican period, a regulation on the duties of the inspectors was published in 1923, the date of the establishment of the Republic of Turkey, which was followed by an instruction on the duties of the inspectors, and the inspectorships were divided into two as central and provincial in 1931, then it merged under the name of proxy inspectorate. The chairman of the Board of Inspectors was established in 1933; a requirement that is to be a graduate of the Gazi Ministry of Education was requested in 1938 for those who want to be inspectors.

In 1990, employment requirements and the conditions of employment were regulated with the Ministry of National Education's Regulation on Primary Education Inspectors (MEB, 1990). In 1999, the Ministry of National Education Elementary Education Inspectors Presidency Regulation reorganized the vocational procurement principles, duty fields and term of office in 1999. (MEB, 1999). With the regulation of Ministry of National Education Inspectors Presidencies issued on 24/06/2011, primary education inspectorate was turned into education inspectorate. In this regulation, supervision, guidance, examination and investigation duties of secondary education institutions were added to the existing inspection, guidance, investigation, and inquiry duties of primary education inspectors (MEB, 2011). The inspection and investigation duties of all the staff working in these institutions were ensured to be carried out by the provincial education inspectors except for the inspection of the secondary education institutions, the guidance of these institutions, and the examination and investigation duties of the teachers working in secondary education institutions.

According to the Decree on the Organization and Duties of the Ministry of National Education No. 652 published in the Official Gazette dated 14/09/2011 and numbered 28054, the title of the education inspectors serving in the provinces has been changed to provincial education inspectors and the ministry 
inspectors serving in the center to ministry inspector (Official Gazette, 2011). Thanks to the Regulation on the Guidance and Inspection Presidency and the Ministry of Education Inspectorates Regulation dated 24/05/2014 and published in the Official Gazette dated 24/09/09, the Regulation of Ministry of Education Inspectorates of the Ministry of Education dated 24/06/2011, which was the previous regulation and to which provincial education supervision / ministerial supervisors were subjected was abolished; besides, the ministry inspectors and provincial education inspectors in the provinces were bonded under the name of maarif inspectors (MEB, 2014). With this amendment, inspection services have been brought into the scope of the central, provincial and foreign organizations of the Ministry, and inspection activities have been abolished in the supervision of the educational institutions.

With the Decree No. 6764 on the Official Gazette dated 09/12/2016 and No. 6764 on the Organization and Duties of the Ministry of National Education and the Law on the Amendment of some Laws and Decrees, the Ministry of National Education Decree of the Directorate of Guidance and Supervision of the Central Organization, the Inspection Board was changed to the form of a maarif inspector (Official Gazette, 2016). In addition to the general requirements in the Civil Servants Law No. 657 , several requirements such as being graduates of law, politics, economic and administrative sciences, economics, business facilities and accreditated to national and foreign higher education institutions as well as being successful from the examination were rearranged.

The tasks assigned to the staff of the Directorate of Guidance and Supervision have been finalized with the law numbered 6764 and the Ministry of Education inspected teachers depending upon the provincial national education managers and assigned the tasks of the Ministry of National Education to perform investigation and guidance services, and investigative duties of maarif inspectors end with this law. It was regulated by this law that the position of the maarif inspectors were turned into a personalized position and these positions would be cancelled if they were vacated; the staff of 500 ministry inspectors and 250 ministry inspector assistants has been assigned in the ministry central organization. The duties, powers and responsibilities of the Board of Inspectors and the working centers, the working procedures and principles, the duties, powers and responsibilities of the ministry instructors and ministry assistant inspectors, the profession, qualifications, appointments, assignments, transfers between centers and other matters to be regulated by regulation are stated in Article 6/4 article with the Law of 6764 .

With this recent change in the sub-system of the Turkish education system, there seems to be no supervisory tasks for the maarif inspectors who will stay in the province. It is unlikely to inspect all the institutions and employees in the education system with the help of 500 maarif inspectors and 250 inspectors who will be in the central organization of the Ministry. Furthermore, it is not required to be a teacher or to be a graduate of faculty of education considering the requirements for the newly appointed ministerial inspectorate staff. The inspections applied in this respect will be largely institutional inspections rather than course inspection and those institution inspections will be predominantly administrative and financial. However, it will be clarified with the regulation to be published following the Law No. 6764 on how and what the inspection will cover.

Particularly in recent years, a rapid change has been observed in the inspection subsystem. Some functional changes with the structural changes such as primary education inspector, education inspector, provincial education supervisor / ministry supervisor, maarif inspector, ministry supervisor inspectorate seems to exist. This gives way for the truth that there is a search for the inspection system. These changes are not actually a discussion of the existence of the inspection's sub-system but a process involving debates about how the structure of the inspection and its function should be. Hence, it is evident that the control subsystem is required in terms of the education system. As for the history of Turkish education, the existence of an ongoing supervision mechanism in educational organizations considers this need; therefore, it will be wise to emphasize the concept of supervision as an indispensable part of education. 
The fact that inspection is an indispensable part of education, that it reveals whether inspection works in accordance with the goals of the school, that it keeps alive in the direction of certain principles and for the purpose of holding the school appropriate with a professional point of view results from its role of functioning. Inspection declares whether a school has a proper life due to its existence. It evaluates the functionality of the teacher, the class and the school in particular, and the objectives of the education system in general. It presents various recommendations to people and institutions on that point through guiding. Clarifying the effectiveness and efficiency of the organization and its employees, inspection has developed in parallel to the development and change in the supervision, education discipline and management discipline. When the definitions of inspection have been examined in the process, this difference is multiplied. Such an understanding that the traditional approach is a process which focuses on the outcome of control and is a controlling purpose has been a more contemporary understanding of guiding the development of people and institutions today as well as preventing problems. Therefore, new inspection models have adopted the notion of guiding teachers through learning by going beyond just identifying the existing situation (Chamberlin, 2000).

Inspection is conducted with various reasons such as overcoming the lack of information, improving the positive aspects of individuals, and guiding them. In this sense, it has a function as an intermediary in helping the students in order to improve his/her success (YIlmaz, 2009). This function of inspection is regarded as a necessity depending on the contemporary management conception; hence it is unlikely to provide efficiency and effectiveness of an uncontrolled administrative process and to renew itself continuously (Ağaoğlu, 2010). This is because the inspection that exists in every complex organization is an organizational and administrative necessity (Memişoğlu, 2012).

Inspection is the method of controlling behaviors on behalf of the public welfare (Bursalığlu, 2012). In a more general sense, inspection is the process of understanding whether organizational actions comply with the principles and rules identified in line with the accepted objectives (Aydın, 2000). In other words, inspection is a process which involves assessing, correcting and improving the level along with determining the level of the realization of organizational goals (Gökçe, 1994). Supervision is also defined as examination, scrutinizing and controlling; it is also regarded as an intentional activity that is always centered on student achievement and development and presupposes educational plans to be carried out accordingly (Badiali, Firth \& Payak, 1997; Glanz, Sullivan\&Shulman, 2007). Supervision is the sum of the actions associated with the concepts of managerial action, curricula, human relations, management and leadership (Wiles \& Bondi, 2000).

The primary aim of an educational inspection is to educate, guide and contribute to the professional development of teachers and increase the level of success in education (Erdem and Eroğul, 2012). As well as enhancing student achievement, developing instructional and educational skills of the teachers are among the other purposes of supervision (Marzano, Frontier \& Livingston, 2011). Thus, the belief in the necessity and significance of educational inspection in the school system is emphasized by all researchers and in particular inspection within the classroom seems inevitable (Aydın, 2005).

The supervision and evaluation in the education system are analyzed in two groups as institution and course inspection. Course supervision is the observation, examination and evaluation of teachers' work in teaching and training activities in an educational institution (Taymaz, 2005). Course inspections may provide the school administration with concrete data on success in the implementation of teaching activities. Sharing positive aspects of the teacher working in the teaching process with himself / herself, informing the teacher about the missing aspects, encouraging him/her to do better, providing unity in teaching, and developing teaching methods applied by the teachers, assisting teachers in the provision and implementation of teaching tools, measuring and evaluating students' success through scientific methods as well as guiding teachers to take responsibility for their problems are considered as the major goals of the supervision (Taymaz, 2005). However, course inspections carried out in accordance with the goal will be functional and contribute to the quality of education and training activities. 
It is a must to measure the success of students in learning in order to find the value of the school's educational and instructional goals. If the school management increases the number of successful students, they are considered to achieve educational objectives. Therefore, supervision process should be able to find out what variables are influencing learning and teaching in school, how they are influential in the educational process, and how to solve the problems in this way (Başaran, 1996). In this sense, course supervision is considered to be an effective tool for improving effective learning environments in schools (Sergiovanni and Starrat, 2002).

Numerous researches have been conducted on the necessity of course supervision. The research results have generally indicated that supervision is an instrument that effectively feels itself in all areas and processes of management and that supervision of organizational action is in compliance with the principles and rules set for accepted purposes especially in the classroom (Aydın, 2000; Aydın, 2005; Erdem \& Eroğul, 2012 b; Sergiovanni \& Starrat 2002).

Structural and functional changes in the sub-system of supervision in Turkey are among the current discussion topics of our education system. With the current practice, course supervision is carried out by school administrators. Discussions on this practice continue among school administrators, inspectors, and other education stakeholders, particularly teachers that have already been dealt with. This process makes the rise of questions inevitable regarding supervision in Turkey as such "Should the course be supervised? If it is done, who should do it? ".

\section{Aim of Research}

This research aims to reveal the views of teachers, school administrators and inspectors on the necessity of course inspections and, if necessary, by whom they are conducted. Hence, answers for the following questions have been sought:

1. What are the views of the teachers, school administrators and inspectors regarding the necessity of the course inspections and whether these require expertise?

2. What are the views of the teachers, school administrators and school inspectors on the positive/negative aspects of the course supervision by school administrators?

3. What are the views of the teachers, school administrators and inspectors on the positive/negative aspects of the course supervision by school inspectors?

4. What are the views of the teachers, school administrators and inspectors regarding the executers of course inspections?

\section{Method}

This section covers sample, data collection tool, data collection and analysis, validity and reliability.

\section{Research design}

This is a qualitative study, based on interview method and it has employed phenomenological design. Qualitative research methods provide with understanding and recognizing the natural environment as well as revealing educational facts as it is susceptible to explain the effects of them on the results. These features diversify educational researches (Yıldırım \& Şimşek, 2011).

\section{Sample}

The research sample consisted of ten teachers and ten school administrators working at state schools affiliated with the Kahramanmaras Provincial Directorate of National Education and ten school working in Kahramanmaras Provincial Directorate of National Education. Table 1 depicts the demographic information concerning the participants. 
Table 1.

Demographic Information about the Participants.

\begin{tabular}{|c|c|c|c|c|}
\hline & & & & Frequency \\
\hline & & $\frac{0}{0}$ & Female & 6 \\
\hline & & ভั & Male & 4 \\
\hline & & & 25-30 Years & 1 \\
\hline & & & 31-35 Years & 3 \\
\hline & & 8 & 36-40 Years & 2 \\
\hline & & & 41-45 Years & 3 \\
\hline & & & 45-50 Years & 1 \\
\hline & & & 1-5 Years & 1 \\
\hline & & $\stackrel{\gtrsim}{\triangleq}$ & 6-10 Years & 1 \\
\hline & d &.$\frac{0}{c}$ & $11-15$ Years & 3 \\
\hline & $\overline{\mathbb{R}}$ & $\bar{\Xi}$ & $16-20$ Years & 2 \\
\hline & $\stackrel{\bullet}{-}$ & & 21-26 Year & 3 \\
\hline & & $\dot{a}$ & 1-5 Years & 1 \\
\hline & & 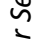 & 6-10 Years & 1 \\
\hline & & $\overline{\grave{s}}$ & $11-15$ Years & 4 \\
\hline & & 8 & $16-20$ Years & 1 \\
\hline & & & 21-26 Years & 3 \\
\hline & & $\overline{0}$ & & Frequency \\
\hline & & ర్ & Female & 2 \\
\hline & & $\tilde{\Xi}$ & Male & 8 \\
\hline & & & $25-30$ Years & 2 \\
\hline ᄃ & & & 31-35 Years & 2 \\
\hline 尊 & ড̀ & & $36-40$ Years & 1 \\
\hline Eㄴ & $\frac{\pi}{4}$ & ơ & 41-45 Years & 1 \\
\hline$\stackrel{\circ}{!}$ & $\frac{n}{5}$ & & 45-50 Years & 3 \\
\hline$\underline{\underline{u}}$ & $\overline{\mathrm{E}}$ & & 60 Years & 1 \\
\hline 등 & 운 & & 5-10 Years & 3 \\
\hline$\frac{\pi}{60}$ & $\overline{8}$ & $\underline{\underline{t}}$ & $11-15$ Years & 1 \\
\hline ڤ̊ & 穵 & 온 & $16-20$ Years & 3 \\
\hline $\bar{\Xi}$ & & 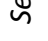 & $21-25$ Years & 2 \\
\hline & & $\lambda$ & 35 Years & 1 \\
\hline & & 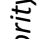 & 1-5 Years & 1 \\
\hline & & $\stackrel{5}{\frac{5}{2}}$ & 6-10 Years & 1 \\
\hline & & $\tilde{5}$ & $11-15$ Years & 4 \\
\hline & & હ & $16-20$ Years & 1 \\
\hline & & হ̀ & 21-26 Years & 3 \\
\hline & & 1 & & Frequency \\
\hline & & $\frac{\bar{d}}{0}$ & Female & 0 \\
\hline & & ভ̃ & Male & 10 \\
\hline & & 0 & $40-45$ & 7 \\
\hline & & ơ & $46-50$ & 1 \\
\hline & 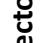 & & $55-60$ & 2 \\
\hline & $\frac{0}{n}$ & $\gtrsim$ & $15-20$ Years & 3 \\
\hline & $\underline{\underline{E}}$ & .ొ & 21-25 Years & 4 \\
\hline & & ฐి & 26-30 Years & 2 \\
\hline & & $\dot{s}$ & 40 Years & 1 \\
\hline & & $\dot{\omega}$ & 5-10 Years & 7 \\
\hline & & nิ & 15-20 Years & 2 \\
\hline & & & 32 Years & 1 \\
\hline
\end{tabular}




\section{Data Collection Tool}

The research data have been obtained through interviews. A semi-structured interview form was used during the interviews. Interview form is composed of 8 open-ended questions that teachers, school administrators, and inspectors are expected to respond. The questions in the interview form prepared by the researcher have been organized by taking the aim of the research into account and using literature review. The questions have been assessed with two academicians in order to determine their content validity. A pilot study has been conducted with a school administrator and a teacher and an inspector before the actual implementation. The aim of the pilot study is to evaluate whether the questions were appropriate for the purpose of the research, whether the questions were clear, whether the order of the questions was appropriate or not, and that there was no problem in terms of purpose and content, and the interview form could be used in the actual implementation. Since the interview form is free from any change, the data obtained from the interviews with 1 teacher, 1 school administrator and 1 inspector were evaluated together with the others. Teachers were counted from T1 to T10, school administrators from SA1 to SA10, and inspectors from 11 to 110 . Teachers, school administrators and inspectors were asked to clarify the positive / negative aspects of course supervision andwho should do course supervision.

\section{Data Collection}

The interviews were conducted between 14/11/2016 and 12/12/2016 on different days and hours. The participants were previously informed about the aim of research and the privacy of the interviews, and they were also asked whether they were volunteers for the participation. The interviews with teachers and administrators were held at the schools where they work and those with the inspectors were held at Kahramanmaras Provincial Directorate of National Education Inspectors. The interviews were conducted in a mutual conversation and the responses of the participants were recorded in the forms by the researcher. The interviews with each person lasted about 30 minutes, and a total of 900 minutes (15 hours) for 30 people. During the interview, the questions directed to the participant were determined beforehand.

\section{Data Analysis}

Content analysis method was used to determine the conceptualization of the data obtained as a result of the interviews and to organize them in a logical way depending on the emerging concepts as well as determining the themes explaining the data accordingly (Yıldırım and Şimşek, 2011). The data were revised by the researcher and codes were determined. Afterwards, the researcher read it for the second time, and several codes were changed. The themes on which the generated codes can be collected and the possible themes have been identified. After codes and themes were determined by the researcher, a field expert and an academician who are competent in the content analysis method have encoded the data and created themes. The codes and themes generated both by the researcher and by the experts were compared. Thus, frequency tables related to coding were presented after the final decision on what codes and themes would be appropriate. Then, findings were determined to be described.

\section{Reliability and Validity}

In the research process, the elements that provide this research's external reliability are the evaluation of the research's methodology in a clear and understandable way by the researcher, data collection, analysis and interpretation of the data, saving raw data so that it can be examined by others. On the other, the researcher evaluates the researcher's methodology and stages, collects data, processes, analyzes, interprets and evaluates what has been done in reaching the results, and hides the raw data of the researcher so that it can be examined by others. It is seen as a clear expression of the research questions, an attempt to gather the research data in a detailed and appropriate manner in the way required by the questions, the coding of the data by the expert of the field expert and the 
comparison of the two different coding are seen as qualifications providing the internal reliability of the research (Yıldırım ve Şimşek, 2011).

The coding made by the researcher, another field expert and an academician were compared with one another and their consistency was examined. The total number of codes obtained from the researchers' coding was determined. The following formula was used to determine the percentage of consistency between the encodings performed by the researchers (Emmer and Millett, 1970; Akt, Selçuk, 2000):

$$
\text { Percentage Consistency }=100\left(1-\frac{A-B}{A+B}\right)
$$

Data analysis has revealed that the number of codes determined by the researcher is 114 , while 70 codes have been identified by another academician. In this case;

Percentage Consistency $=100\left(1-\frac{114-70}{114+70}\right)$

Percentage Consistency $=\% 76$

Given the consistency between coding is $75 \%$ and over (Emmer and Millett, 1970; Akt. Selçuk, 2000), the consistency between the encodings shows that the level of consistency between the two encodings is consistent.

\section{Findings}

\section{The Need for Course Supervision}

Table 2 displays the themes and codes regarding the analysis of the views of the teachers, school administrators and inspectors in terms of the necessity of the course supervisions are given in Table 2. 
Table 2.

The Views of Teachers, School Administrators and Inspectors on the Need for Course Supervision.

\begin{tabular}{|c|c|c|c|c|c|}
\hline \multirow{15}{*}{ 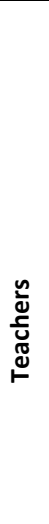 } & \multirow{15}{*}{ 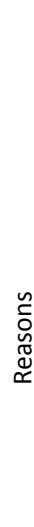 } & \multirow{7}{*}{ 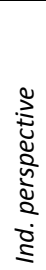 } & The need for course supervision & \multicolumn{2}{|c|}{ Frequency } \\
\hline & & & Course supervision is required & & 10 \\
\hline & & & The Identification of performance & & 2 \\
\hline & & & Training Teachers & & 2 \\
\hline & & & Prevention of job relaxing & & 1 \\
\hline & & & Providing motivation & & 1 \\
\hline & & & The Significance of supervision score & & 1 \\
\hline & & & & Total & 7 \\
\hline & & & Making assessment & & 3 \\
\hline & & ร & Distinguishing between those who do work or not & & 4 \\
\hline & & 壳 & Scheduling & & 1 \\
\hline & & $\frac{2}{n}$ & Accountability & & 1 \\
\hline & & $\frac{8}{2}$ & Control & & 1 \\
\hline & & 2 & Prevention of ideological approaches & & 1 \\
\hline & & రั & & Total & 11 \\
\hline & & & The need for course supervision & Frequ & ency \\
\hline & & & Course supervision is required & & 10 \\
\hline & & $\stackrel{0}{3}$ & Determining performance & & 2 \\
\hline & & 芯 & Providing motivation and self-confidence & & 2 \\
\hline & & ș & Identification of desired behavior & & 2 \\
\hline & & ¿ & Prevention of job degradation & & 1 \\
\hline 할 & & $\dot{0}$ & Feedback presentation & & 1 \\
\hline$\stackrel{0}{\stackrel{0}{4}}$ & & $\leqslant$ & & Total & 8 \\
\hline$\stackrel{\underline{a}}{\leftrightarrows}$ & & & Detection and removal of deficiency & & 4 \\
\hline$\overline{\mathrm{E}}$ & ర్ & ๖ & $\begin{array}{l}\text { Identification of the accomplishment levels of } \\
\text { the objectives }\end{array}$ & & 3 \\
\hline$\overline{\mathrm{o}}$ & $\ddot{\sim}$ & 壳 & Presenting opportunities for management & & 1 \\
\hline 悹 & & 㝕 & Provision of preparing instructional plans & & 1 \\
\hline & & ¿ & Sanction power & & 1 \\
\hline & & ọ & Ensuring status assessment & & 1 \\
\hline & & $\overline{0}$ & Control & & 1 \\
\hline & & & Increasing business quality & & 1 \\
\hline & & & & Total & 13 \\
\hline & & & The need for course supervision & Frequ & ency \\
\hline & & & Course supervision is required & & 10 \\
\hline & & & Follow-up program applications & & 4 \\
\hline & & & Identification of performance and sufficacy & & 4 \\
\hline & & : & Guiding candidate teachers & & 1 \\
\hline & & $\frac{8}{2}$ & $\begin{array}{l}\text { Prevention of prejudice in educational } \\
\text { activities }\end{array}$ & & 1 \\
\hline & & $\frac{2}{2}$ & Creating program awareness & & 1 \\
\hline ఫ̀ & $\stackrel{n}{\check{c}}$ & $\underline{s}$ & $\begin{array}{l}\text { Identification of the use of teaching methods } \\
\text { and techniques }\end{array}$ & & 1 \\
\hline$\frac{\varpi}{n}$ & 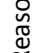 & & & Total & 12 \\
\hline & & 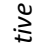 & Detection and removal of deficiency & & 4 \\
\hline & & 芯 & Identification of the accomplishment levels of the objectives & & 2 \\
\hline & & $\frac{2}{2}$ & Taking Preventive Measures & & 1 \\
\hline & & ฉ & Guidance / controlling need of multi-graded schools & & 1 \\
\hline & & வ் & State's control & & 1 \\
\hline & & & & Total & 9 \\
\hline
\end{tabular}

Table 2 presents that all the teachers, school administrators and inspectors have opinions about the necessity of course supervision. The requirement of supervision has been examined on the basis of individual and organization. Teachers express the necessity of supervision on the basis of individual with such reasons as "identification of teachers' performance, teacher training, providing teachers' motivation, prevention of teachers' job relaxing, teachers' desire for working more so that they will not 
feel embarrassed towards their colleagues due to the supervision scores". Teachers mostly emphasize the identification of teachers' performance and development of teachers as the need to supervise.

Teachers signify the need for supervision in terms of such reasons as "distinguishing between those who do work or not, scheduling, control, accountability, prevention of ideological approaches". Teachers mostly note distinguishing between those who do work or not and performing education and teaching activities as the necessity for supervision. In this case, they have the strong belief that a distinction can be ascertained between those who work and who do not only through supervision. The role of supervision in all systems is to put a photograph of the functioning of the system. What teachers also expect from supervision is to reveal every aspect of functioning and detect all cases related to the educational activities.

Here are some excerpts to illustrate the explanations of teachers during the interview related to the supervision compulsory on the basis of individual and organizations:

"... So our motivation and the evaluation of our own work should be done in order to see the missing and positive aspects, but if you are objective" (T3)

"... When teachers are not supervised, they shut themselves against development and change. Supervision is essential to measure the degree to which educational objectives are achieved." (T6)

"... There are now very relaxed teachers and they have different levels of consciousness. Thus, Supervision is required. There are very old teachers and they have nothing to do. Supervision must be carried out to distinguish between those who work and who do not. An individual under control makes things better. Control is essential. As a result of the evaluation, teachers will work better in order not to encounter a lower evaluation result by their colleagues. Evaluation has been made among teachers about the scores they have, whether evaluation is objective. This reveals the significance and necessity of supervision." (T7)

"... because there are truths that are tailor-made and general. These judges guide teachers. Supervision is required in order not to reflect ideological ideas and views to the education. We ask our child about the amount of $1 \mathrm{TL}$. The government will, of course, supervise where education is. Supervision must be conducted to ensure accountability." (T8)

School administrators express several reasons for the requirement of supervision as "determining teachers' performance, increasing motivation and self-confidence of teachers, identification of desired behaviors, and prevention of job degradation". In this regard, school administrators are more convinced that it is necessary to supervise the performance of the teachers, increase their motivation and selfconfidence, and examine the positive aspects of their behaviors. The performance evaluation role of supervision is also considered as significant for administrators. Supervision is not just an assessment. It also has the role of providing moral support and remedial of institutional climate taking human relations into account. Thus, supervision seems to be important for the school administrators to provide motivation and self-confidence.

School administrators stated the need for supervision on the basis of organization with various reasons; "managing organizations, identifying and avoiding the shortcomings of education and teaching activities, examining the situation of teaching plans, assessing the situation, increasing the quality of the work, determining whether the education and training activities are carried out, determining the realization levels of the goals / targets and acquisitions, ensuring that teachers receive feedback on their work, providing control and enforcing sanctions".

School administrators view course supervision as a more organizational necessity. This may be due to the fact that supervision is regarded as a part of management. It is a process including assessment, correction and improvement. The necessity expressed by school administrators represents these functions of supervision.

Here are some excerpts that may be examples for the school administrators' explanations: 
"I think course inspections should be performed as there is a say in administration. If you do not make an inspection, you do not rule. "(SA1)

"... The inspection should be continuously and periodically conducted to determine the extent to which the teachers have achieved the acquisitions within the program." (SA2)

"... The business quality of an institution depends on a good inspection." (SA3)

"... Because we cannot do anything without control. Teachers act free when there are no course inspections. "(SA4)

"... I think it is necessary for the positive evaluation of the teachers to raise their motivations and selfesteem in order to reveal the unrecognized wrongs and deficiencies." (SA5)

"... because it is necessary to motivate teachers." (SA7)

When the views of the inspector on the necessity of the course inspections on an individual basis have been analyzed, supervision is considered as a requirement for the reasons of "identification of the implementation level of the programs, identification of teacher performance and competencies, development of prospective teachers, prevention of arbitrariness in the education and training process, increasing awareness of the teachers related to curricula and identification of the use of teaching principles and methods in teaching activities".

Inspectors have emphasized the necessity of inspection organizationally by presenting several reasons such as "requirements for elimination of deficiencies and mistakes made in the educational process, identification of the access to educational goals / objectives / acquisitions, taking preventive measures, meeting the need for guidance of consolidated classrooms, providing the control of the government".

Some excerpts related to the explanations of the inspectors are presented as following:

"... Findings about the correctness and inadequacy of educational activities take place only with supervision. We can only observe the implementation of the techniques through inspection. In this regard, taking precautions in the educational curriculum, carrying out preventive activities and preventing the harms of the intervention are required"(I1)

"... Inspection should be performed at least for the prospective teachers and in the multigrade classes. Supervision is necessary for the detection and elimination of deficiencies of teachers. "(14)

"... First, it is inevitable to determine the deviations about the program-oriented education and training, and to identify the center of the related program. It is also vital for creating teacher awareness about the program. "(I7)

"... because when the objectives of the lessons are realized, the general aims of the school will be achieved. In this respect, it is very appropriate to conduct course inspections for the corrective action. "(19)

All inspectors have emphasized the necessity of course inspections. They have mostly indicated that supervision should be carried out in order to determine the implementation of the teaching programs, to reveal the teacher performance and competence, to eliminate the incomplete and inaccuracies related to the education and training activities. Inspection may be referred as a necessary process to realize various roles in terms of status identification, evaluation, correction and development. It also turns out that inspection has a significant role in controlling the achievement level of educational goals/objectives/acquisitions, the control of educational activities within the classroom.

\section{Course supervision as a Specialization-Required Area}

The question whether course supervision is a specialization-required area or not and if it is a specialization -required area, the underlying reasons depending on the codes and themes are presented in Table 3. 
Table 3.

Reviews on Course supervision as a Specialization-Required Area.

\begin{tabular}{|c|c|c|c|c|}
\hline \multirow{7}{*}{ 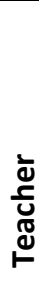 } & \multirow{7}{*}{ 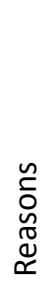 } & Is Course supervision a Specialization-Required Area? & Freque & ncy \\
\hline & & Course supervision is a specialization-required area. & & 10 \\
\hline & & Having full knowledge of the field & & 8 \\
\hline & & Having a supervision certificate & & 6 \\
\hline & & Sufficiency in human relations and communication & & 4 \\
\hline & & Experience as teacher and inspector & & 2 \\
\hline & & Having knowledge about age groups & & 2 \\
\hline \multirow{12}{*}{ 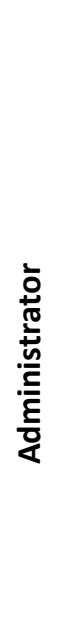 } & \multirow{12}{*}{ 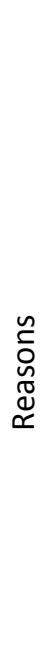 } & & Total & 22 \\
\hline & & Is Course supervision a Specialization-Required Area? & Freque & ncy \\
\hline & & Course supervision is a specialization-required area. & & 10 \\
\hline & & Having full knowledge of the field & & 5 \\
\hline & & Sufficiency in human relations and communication & & 4 \\
\hline & & Professional experience & & 3 \\
\hline & & Having a supervision certificate & & 2 \\
\hline & & Having knowledge about the related regulations & & 2 \\
\hline & & Being innovative and having vision & & 2 \\
\hline & & $\begin{array}{l}\text { Ability to manage crisis, producing practical } \\
\text { solutions }\end{array}$ & & 1 \\
\hline & & Time management & & 1 \\
\hline & & Having knowledge about students' development & & 1 \\
\hline \multirow{8}{*}{ 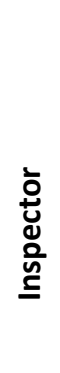 } & \multirow{8}{*}{$\begin{array}{l}\tilde{n} \\
\check{0} \\
\mathscr{n} \\
\tilde{\Xi} \\
\check{\simeq}\end{array}$} & & Total & 21 \\
\hline & & Is Course supervision a Specialization-Required Area? & Freque & ncy \\
\hline & & Course supervision is a specialization-required area. & & 10 \\
\hline & & Having professional knowledge on teaching & & 7 \\
\hline & & Having a supervision certificate & & 5 \\
\hline & & Having full knowledge of the field & & 4 \\
\hline & & Professional experience & & 2 \\
\hline & & & Total & 18 \\
\hline
\end{tabular}

As is seen in Table 3, all of the teachers, school administrators and inspectors have stated that course supervision is a specialization-required area.

As for the reason why course supervision is a specialization-required area, teachers state that "in order to do course supervision, one should have full knowledge of the field, supervision formation, knowledge about the age groups of the students, be sufficient in human relations and communication, experienced in teaching and supervision". Teachers believe that having full knowledge of the field is mostly required expertise for course supervision. It can be stated that knowing curriculum, being aware of the educational attainments in the curriculum, their knowledge sufficiency of how to transfer these attainments, their technical sufficiency of curriculum and having full knowledge of the field consist the most of the expertise of inspectors.

Supervision is considered as a discipline which possesses its own principles and rules by the teachers. Therefore, course supervision is a specialization-required area which is run by its own principles and rules within a certain time period. Teachers have emphasized that it is required to be sufficient in human relations and communication for the expert who is responsible for the course supervision.

Some quotations which can be the examples to teachers' expressions are presented as such: 
"... Inspector must have full knowledge of the related field. "Inspector should be sufficient in human relations and communication." (T1)

"In order to do a valid evaluation, an inspector should know every detail about the field and have full knowledge of the related field." (T3)

"... I am a kindergarten teacher. The one who will supervise me must be an expert at his/her own field. S/he must know how and what to supervise. Otherwise, some of the teacher actions can be ignored. S/he must know the general characteristics of the related age group. An inspector must have enough technical knowledge about supervision" (T4)

"... An inspector must know what to supervise and adjust his/her attitude depending on the teacher before him/her that is why it is a specialization-required area. Must be aware of the processes and have full knowledge on supervision in each premise. (T9)

As a reason why course supervision is a specialization-required area, school administrators have stated that "in order to do course supervision, the one should have full knowledge of the field, be sufficient in human relations and communication and time management, be experienced in teaching and supervision and have supervision formation, knowledge about the related regulations, and the ability to manage crisis and produce practical solutions, be innovative and have vision, knowledge about the age groups of the students." Administrators regard having full knowledge of the field and sufficiency for human relations and communication as specialization-required areas. An inspector should have competency for curriculum and communication skills.

Some quotations which can be the examples to school administrators' expressions are as following:

"... Since supervision is a scientific field, education in this area is a must." "Human relations, time management, crisis management require specialization" (SA1)

"... In order to help the others, it important to have full knowledge of the field" ... Supervision requires technical skill and knowledge. Therefore, everyone cannot do supervision."(SA2)

"... Only academic expertise is not enough, an expert must be competent for human relation, has a vision, follows the innovations in the field and applies them in his/her working field. Moreover, I think, experts must be those who can think practically, develop practical methods, solutions and use them." (SA5)

"... Everything requires specialization. You need to know how to supervise, otherwise. ... Must know the field and teaching. Must be an expert at the field such as curriculum. Needs to know the related regulations very well." (SA7)

".... Supervision must be done by those who are expert at supervision, know the principles, processes and aims of supervision." (SA8)

"... I have been working as a school administrator for 35 years. I have 4 years of teaching experience. In order not to be stuck in a different situation against the teacher, I check the curriculum. I need to be competent in any ways..." (SA9)

As the reason why course supervision is a specialization-required area, inspectors have noted that "in order to do course supervision one should have professional knowledge in teaching, supervision formation, full knowledge of the field, experience in teaching and supervision." Inspectors have stated that course supervision is a specialization-required area and having teaching experience is the most important component in this expertise. Professional knowledge of teaching means pedagogical formation, knowledge of the field and world knowledge. Not only teachers but also inspectors must be competent in the presented fields. Inspectors highlight that course supervision is a discipline and that the principles and rules of the discipline must be fully known; therefore, course supervision is a specialization -required area.

Some quotations which can be the examples to inspectors' expressions are given below:

"... Because every lesson is different from one another, it would be wrong for a science teacher to supervise/guide an English teacher." (I1) 
"... Since teaching profession is equipped by pedagogical field and world knowledge, the supervision of the profession must be done by someone coming inside the profession, in this way understanding and showing empathy will become easier. I also think that supervision is a field requiring some professional and technical knowledge and skills." (12)

"... Must have some experience, knowledge and background related to education. There are administrators, rules and processes related to supervision discipline. Supervisor must be sufficient for these processes. Communication is the most important sufficiency among them."(I4)

"... Knowing how to teach and learn requires having pedagogical formation." (15)

"... First of all inspectors must have full knowledge of curriculum because it is important in terms of being aware of the philosophy of education. Being aware of the certain principles, rules and processes of supervision requires specialization." (17)

\section{Specialization of Administrators on Course Supervision}

The question whether administrators are experts at course supervision or not and the underlying reasons depending on the codes and themes are shown in Table 4.

Table 4.

Reviews on Specialization of Administrators on Course supervision.

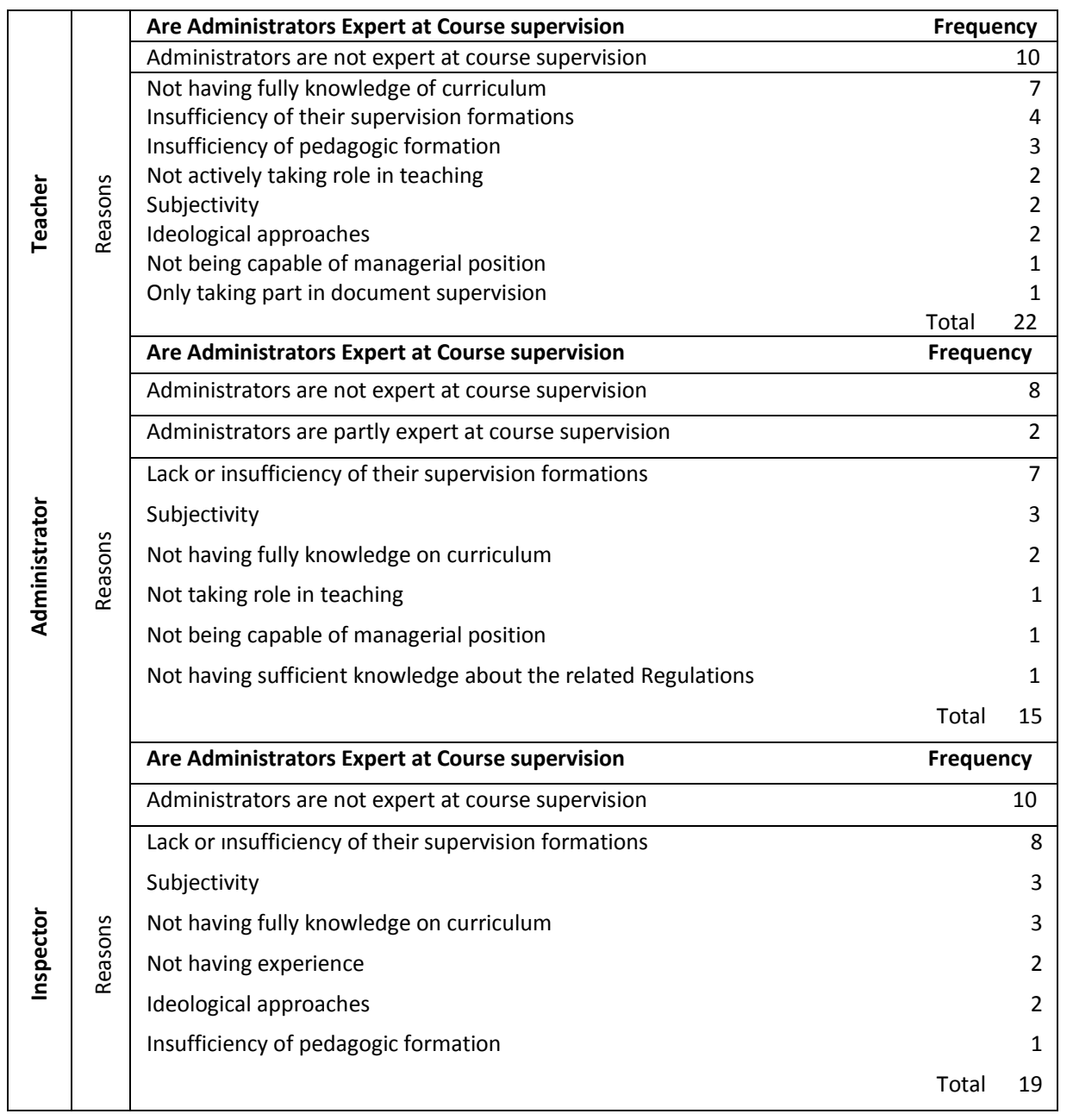

In Table 4, all of the teachers, inspectors and most of the school administrators (8/10) have concluded that they are not experts at course supervision and 2 of the school administrators stated that 
they are partly expert at course supervision. Therefore, as a part of supervision, teachers, school administrators and inspectors do not think that administrators are experts at course supervision. It is noteworthy that administrators doing course supervision depending upon current regulation do not see themselves as experts.

Research data as a result of content analysis about the reason why administrators are not regarded as experts at course supervision are presented below:

Teachers state that administrators are not experts at course supervision. The underlying reasons are; "Administrators do not have full knowledge in curriculum, supervision formation or their insufficiency in this regard, insufficiency in pedagogical formation, not taking role in teaching for a long time, not being objective in the evaluation process, behaving in an ideological way during evaluation, not being capable of managerial positions. Teachers' perceptions on the fact that administrators are not experts in course supervision mainly focus on not having full knowledge of curriculum, supervision and pedagogical formation.

Some quotations which can be the examples to teachers' expressions are presented below:

"... Administrators should not be interested in politics. I think that because of the ideological approach, there is no expertise." (T1)

"Because of taking role in managerial positions and staying away from teaching, I do not think that they are experts at course supervision. Should have full knowledge of the principles and processes of supervision to supervise the lessons in a professional way". (T3)

"... Because of being veteran, having their last years in the profession, not being open to innovation I think that they are not experts at course supervision." (T6)

"... Some have good, some have bad and some have neutral relation with school administration. This situation will have reflections on the evaluation so naturally it will cause bias on it. Since the administrative people have not been teaching for a long time, they will not be capable of course supervision." (T7).

"... I do not think that school administration is consisted of efficient people. I do not think that administrators act in an objective way during performance evaluation process. Administrators might behave in a biased way because of their own relations and ideologies."(T9)

"... Not having full knowledge of the field is an insufficiency for administrators. "... In the supervision process administrators only inspect classroom organization and documents. Actually supervision does not seem like educational attainment supervision." (T10).

School administrators state that administrators are not experts at course supervision. They base this view on the following reasons: "Not having supervision formation or their insufficiency for this regard, not being objective in the evaluation process, not having full knowledge of the curriculum, not actively taking part in teaching for a long time, not being capable of managerial positions, not having full knowledge of the related regulation." As for the reason why administrators are not experts at course supervision, school administration mainly mention "not having supervision formation or their insufficiency in this regard, not being objective in the evaluation process and not having full knowledge on the curriculum. Only two of the administratorsSA3 and SA7 claimed to be partly expert at course supervision.

Some of the quotations which can be the examples to school administrators' expressions are given below:

"... Supervision is a scientific process. Since they are not taken the required training for supervision, they are not experts. Supervision skills are not at the required level. It is high likely to give emotional decisions because of the close relationship between the teacher." (SA1)

"... They do not have enough knowledge of the curriculum and they are not sufficient for supervision process. Supervision is another discipline Supervision is another discipline in order to have full knowledge 
of the principles and rules of the disciple and apply them, a special expertise is required. I do not think that administrators have such expertise." (SA12).

"... A school administrator who has full knowledge of its staff and institution can be sufficient for course supervision. But there might be insufficiencies in curriculum." (SA3)

"... Most of the school administrators are away from teaching for a long time. In this case I do not think that they can be objective. ... Since there is no reliability in the selection process of the school administration, they will not be sufficient for course supervision." (SA5)

The reason for insufficiencies of administrators for course supervision can be listed as not training themselves for course supervision and not having full knowledge on the principles and processes of course supervision." (SA7)

Inspectors state that school administrators are not experts at course supervision. They explain the reasons in the following statements: "Not having supervision formation or their insufficiencies in this regard, not being objective in the evaluation process, not having full knowledge of curriculum, being inexperienced, insufficiencies in pedagogical formation and their ideological approaches." As for the reason why administrators are not experts at course supervision, inspectors mainly mention not having supervision formation or their insufficiency in this regard, not being objective in the evaluation process and not having full knowledge on the curriculum. Teachers, school administrators and inspectors are of a single mind about the matter.

Some of the quotations which can be the examples to inspectors' expressions are given below:

"It is stated that administrators are not interested in their staff's complaints, they evaluate the situation according to their ideological approach and they do not act in an objective way." (I2)

"... Supervision requires specialization. Since they are not taken education on course supervision, I think that they in sufficient for this matter." (I3)

"Absolutely not. Both teachers and administrators complain about this situation. Because school administrators are not aware of the principles and processes of course supervision. Course supervision can be done in a subjective way regarding political and ideological situations which makes the supervision nonobjective." (15)

"Depending on the reason that they work together for a long time, they have close friendship and relationship with each other which makes the supervision nonobjective." (I8)

\section{The Positive Sides of Having Course Supervisions Done by School Administrators}

Table 5 displays the codes and themes regarding the positive sides of having course supervisions done by school administrators. 
Table 5.

Reviews on the Positive Sides of Having Course Supervisions Done by School Administrators.

\begin{tabular}{|c|c|c|}
\hline \multirow{7}{*}{ 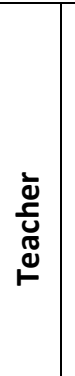 } & \multirow{7}{*}{ 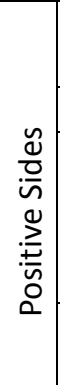 } & $\begin{array}{l}\text { Are There Any Positive Sides of Having Course supervisions Done by } \\
\text { School Administrators? }\end{array}$ \\
\hline & & Yes there are \\
\hline & & Know the staff and institution in a better way \\
\hline & & Constant observation \\
\hline & & Having knowledge about the process \\
\hline & & Total 13 \\
\hline & & $\begin{array}{l}\text { Are There Any Positive Sides of Having Course supervisions Done by } \\
\text { School Administrators? }\end{array}$ \\
\hline \multirow{12}{*}{ 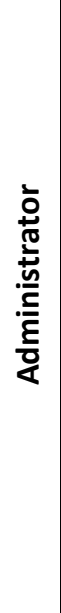 } & \multirow{9}{*}{ 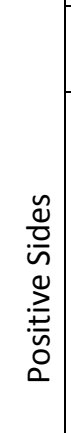 } & Yes there are \\
\hline & & No there are not \\
\hline & & Knowing teachers better \\
\hline & & Knowing students, parents and environment better \\
\hline & & Creating constant feeling of supervision \\
\hline & & Knowing the institutional problems \\
\hline & & Not being alienated from education \\
\hline & & Providing constant observation chance \\
\hline & & Dealing with the fear of inspector term \\
\hline & \multirow{9}{*}{ 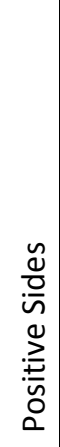 } & Total 15 \\
\hline & & $\begin{array}{l}\text { Are There Any Positive Sides of Having Course supervisions Done by } \\
\text { School Administrators? }\end{array}$ \\
\hline & & Yes there are \\
\hline \multirow{6}{*}{ 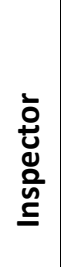 } & & No there are not \\
\hline & & Having knowledge about the process \\
\hline & & Knowing teachers better \\
\hline & & Easiness in post-supervision process \\
\hline & & Chance of giving timely response to problems \\
\hline & & Total 8 \\
\hline
\end{tabular}

In Table 5, the data regarding the participants' perceptions towards the positive sides of having course supervisions done by school administrators are as following:

Teachers mention the following as the positive sides of having course supervisions done by school administrators: "knowing the staff and institution in a better way, chance of having constant observation and full knowledge of the process. Teachers mainly emphasize that knowing the institution and teachers as the most positive sides of having course supervisions done by school administrators.

Some quotations which can be the examples to teachers' expressions are as such:

"... As opposed to someone out of the institution, administrators have more foreknowledge. Knows institution, staff better." (T1)

"... The biggest advantage is that $\mathrm{s} / \mathrm{he}$ is always together with the teachers therefore s/he has better chances to observe and know the teachers. Because supervision done by the inspector takes a day (1-2 hours)." (T2)

"... Since s/he has a constant chance of observing us, it is an advantage of it." (T4)

"... Administrator gets to know the teachers during the school year and during the supervision s/he can take these into consideration." (T5). 
"... When we had an inspector, we would say that "I hope the inspector visits us in the class we expect, not any of the bad classes." (T7)

School administrators have indicated the following as the positive side of having course supervisions done by school administrators: "knowing the staff and institution in a better way, chance of having constant observation and full knowledge of the process." School administrators mainly state that knowing students, parents and environment better as the most positive side of having course supervisions done by school administrators. One of the school administrators state that there is not an advantage of having course supervisions done by school administrators.

Some of the quotations which can be the examples to school administrators' expressions are given below:

"... Knowing and considering the physical environment, having general knowledge about the students and their parents, because of constantly being together, having better knowledge about the teachers' skills..." (SA1)

"... I think there are not any advantages" Nowadays, supervision is not done in the way it is supposed to be." (SA4)

"... Since the teacher is constantly at school during the day, administrator can always observe the teacher." (SA6)

"... Since the school administrator is always at school, so the supervision becomes constant. Since the supervision by inspectors is for 1-2 days, the time is limited."(SA9)

Inspectors have emphasized the following as the positive sides of having course supervisions done by school administrators: "having full knowledge of the process, easiness in post-supervision process, chance of giving timely response to problems". Inspectors mainly state that having full knowledge of the process and knowing the teachers in a better way as the most positive side of having course supervisions done by school administrators. Three of the inspectors noted that there is no advantage of it (I5, I7, and I10).

Some of the quotations which can be the examples to inspectors' expressions are given below:

“... School administrators have some advantages as they are the direct followers of the process, they have the chance of observing with their own eyes therefore they have the chance of observe ring and evaluating the situations at the time they happen if they see any problems, and they can timely interfere in the process as well." (12)

"... Has the option to supervise and follow the changes after it but inspectors do not have this chance."(14)

"... I have never seen any satisfied administrators, they do not have the supervision sufficiency moreover some of them do not know teachers working at their institution." (15)

"... If it is done in an amateur way, it is harmful for teacher, teaching and learning process and institution." (16)

"I think there are not any advantages" "It is not positive because supervisor must be aware of supervision criteria for his/her own field and supervision should be professionally done, so administrators do not have these competencies." (I7)

Teachers, school administrators and inspectors refer to knowing the teacher in better way as an advantage of having the supervision done by school administrators.

\section{The Negative Sides of Having Course Supervisions Done by School Administrators}

Table 6 depicts the codes and themes regarding the negative sides of having course supervisions done by school administrators. 
Table 6.

Reviews on the Negative Sides of Having Course Supervisions Done by School Administrators.

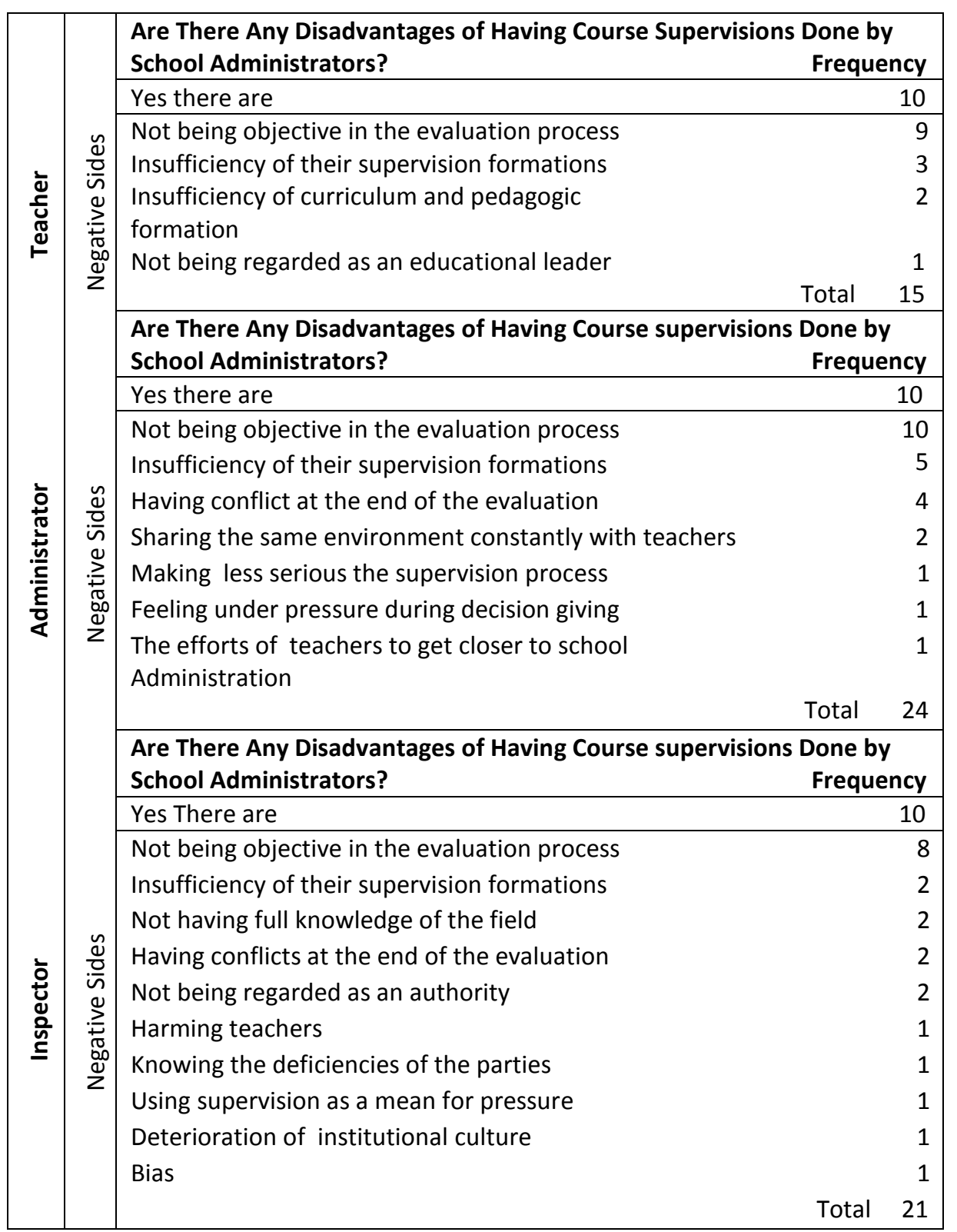

Table 6 presents the data regarding the negative sides of having course supervisions done by school administrators:

Teachers signify the following as the negative sides of having course supervisions done by school administrators: "not being objective in the evaluation process, insufficiency of their supervision formations, not being regarded as an educational leader, insufficiency of curriculum and pedagogic formation." Teachers mainly state that not being objective in the evaluation process, insufficiency of their supervision formations, insufficiency of curriculum and pedagogic formation as the most negative sides of having course supervisions done by school administrators. 9 of the 10 interviewed teachers have stated that administrators act in a subjective way during course supervision process for evaluating teachers' performance. 
Some quotations which can be the examples to teachers' expressions are given below:

"... Subjectivity is the matter. Let's imagine two teachers having the same situation. Although it is expected to have same outcomes, they are not treated in the same way." (T1)

"... I mean the thing is. Problems arise if the administrator acts in a biased way. I think there are some insufficiencies regarding supervision discipline".(T2)

"... I think the most important disadvantage is, since they have taken an active role in the administration for a long time, they have limited knowledge about the curriculum. Reflection of the personal problems and relation on the evaluation process is one of the disadvantages." (T4)

"... If there are some teachers who have good or bad relations with the administration, objectivity has come to an end and subjectivity and bias start. Field and pedagogical insufficiency decrease the supervision validity. Injustice evaluation in performance scoring causes disturbance and it causes problem in the institution." (T5)

"... If teachers suspect an injustice evaluation, it affects the profession negatively and causes conflicts among the teachers working in the institution." (T7)

"... There are. Subjectivity in supervision causes disturbance in the institution." (T8)

"... The only disadvantage that I thought is the situations in which the administrators behave in a biased way. As a result of disturbance which is created by biased evaluation affects the institution negatively and therefore working performance of teachers decrease..." (T10)

As for the disadvantages of having course supervisions done by school administrators, administrators have determined that: "not being objective in the evaluation process, insufficiency of their supervision formations, having conflict among administrator-teacher/ teacher-teacher at the end of the supervision, negative effects of always sharing the same place with the teachers, teachers' efforts for having good relationship with the school administrators in to order to get better scoring, keeping administrators under pressure during the decision process and the problem of making the supervision process less serious. School administrators have concluded that the main disadvantages of having the course supervision done by the school administrators are as not being objective in the evaluation process, insufficiency of their supervision formations, having conflict among administrator-teacher/ teacherteacher at the end of the supervision. Upon analyzing the percentage of the negative thoughts on having the course supervision done by the school administrators, the percentages of the school administrators' negative comments are higher than those of the teachers and inspectors.

Some of the quotations which are the examples to school administrators' expressions are as follows:

"... Always being at the same place with the supervisor and people being supervised causes a nervous atmosphere, favoritism, and teachers act in a way to have good relations with the inspectors and it decreases the importance of supervision in people's mind." (SA2)

"... Since school administrators know the teachers beforehand, they act in a biased way during the supervision. They cannot be objective. Moreover, since they do not take part in active role in teaching, I think that their supervision is not sufficient. I mean they do not anything about the field which they supervise." (SA4)

"... Since they see each other every day, they may avoid telling the necessary things or warning them in order not to have bad relations." (SA6)

As for the disadvantages of having course supervisions done by school administrators, inspectors refer to the facts of not being objective in the evaluation process, insufficiency of their supervision formations, not having full knowledge of the field, knowing each other's deficiencies as supervisors and people being supervised, using supervision as a pressure tool, deterioration of the institutional structure at the end of the supervision, being biased during the supervision. Inspectors highlighted that as for the main disadvantages of having the course supervision done by the school administrators as not being 
objective in the evaluation process, insufficiency of their supervision formations and not having full knowledge of the field.

Some of the quotations which may be the examples to inspectors' expressions are given below:

"... Positive decriminalization can be a matter and this causes polarization and lack of confidence in the institution." (I1)

"... Sometimes supervision is used as a mean for making pressure." They may not behave fairly. Because they can act unfairly to people who do not share the same ideas with them." (14)

Teachers, school administrators and inspectors have determined behaving in a subjective way as a disadvantage of having the supervision done by school administrators. Moreover, since school administrators do not have supervision formation or they are insufficient for this regard may arise as other negative sides of the matter.

\section{The Positive Sides of Having Course supervisions done by Inspectors}

The codes and themes regarding the negative sides of having course supervisions done by school administrators are as in Table 7. 
Table 7.

Reviews on the Positive Sides of Having Course supervisions done by Inspectors.

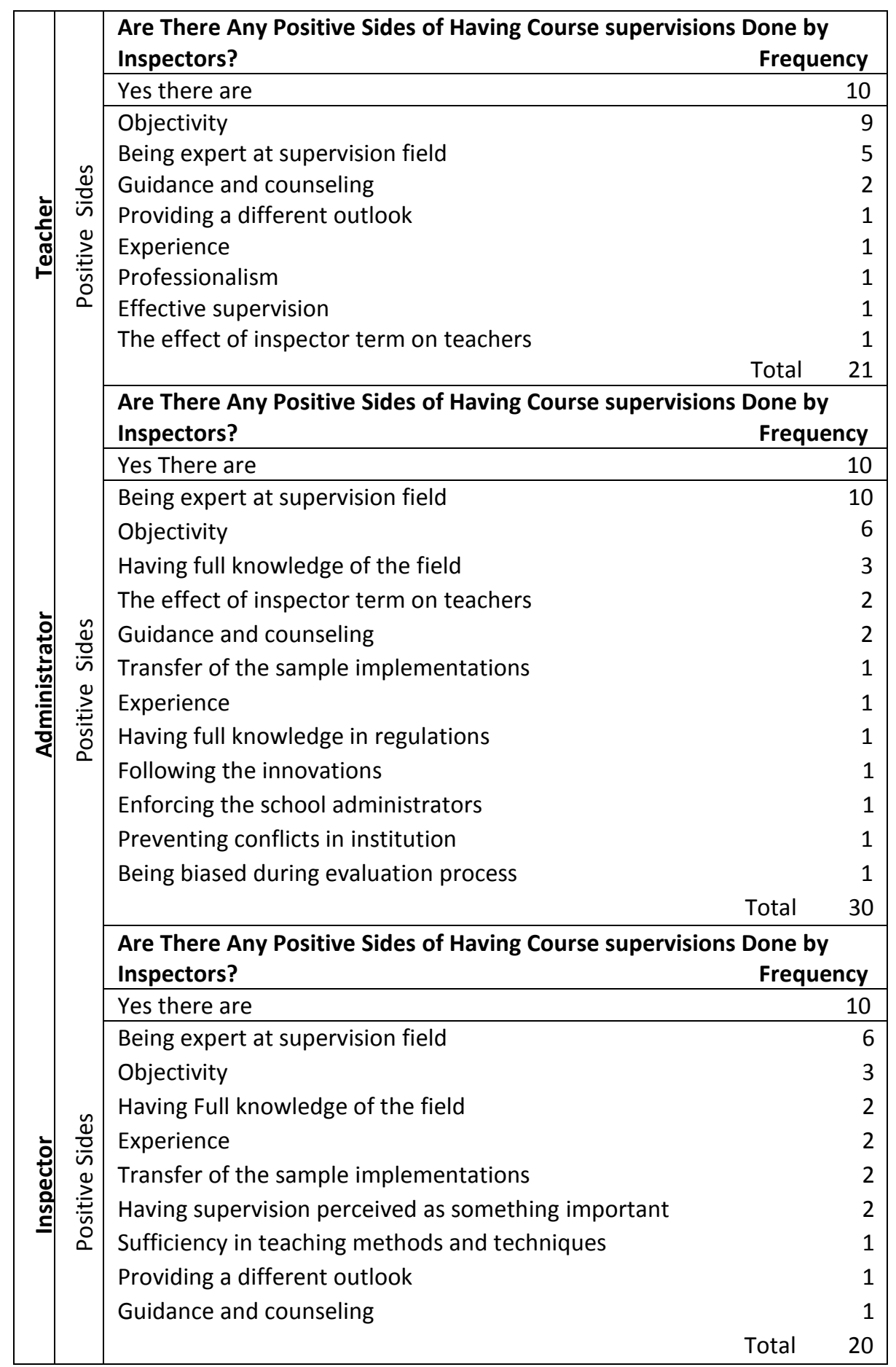

The findings regarding the positive sides of having course supervisions done by inspectors are as in Table 7: 
As for the advantages of having course supervisions done by inspectors, teachers state that: inspectors are objective in evaluation and supervision, they are able to guide and counsel teachers, they can provide different outlook to institution and teachers, they are experienced and professional, they are effective at supervision, the effect of inspector term reflect on the teaching and training process in a positive way. Teachers highlighted that as for the main advantages of having the course supervision done by the inspectors as being objective in the evaluation process, expert at supervision and guidance and counseling that they make. Despite stating that school administrators are not objective (10/10), teachers state that inspectors are objective during supervision and evaluation process (6/10).

Some quotations which can be the examples to teachers' expressions are given below:

"... I think they supervise in a more objective way. Since they are experts at the field, they have a more qualified supervision.

"... The supervision and guidance of the done by the inspectors help teachers to notice our deficiencies in the field "since the inspector evaluates the situation depending on the things s/he observes, s/he does not act in a biased way, s/he is more objective." (T2)

"... At least they guide and counsel and make constructive critics Inspector term means pressure therefore teacher feels a need to work harder. Inspector is more objective." (T5)

"Since the inspector is somebody out of the institution and I believe that they are experts, I think it is better to have supervision by inspectors." (T6)

"... Since they always have supervision, they are more professional."( T8)

"... They are more objective, since they are professionals they have a more scientific supervision." (T10)

As for the advantages of having course supervisions done by inspectors, school administrators state that: they are experts at the supervision field, objective, they have full knowledge of the field and curriculum, inspector term has a positive effect on teachers, they have roles of guidance and counseling, they are transferring model implementations from one place to another, experienced, they have full knowledge of regulations, they are aware of the innovations in the field and objective, they prevent the conflict which can happen at the end of the supervision, they enforce the school administrators. Despite mostly stating that school administrators are not objective (9/10), school administrators also state that inspectors are objective during supervision and evaluation process (9/10). As for the advantages of having course supervisions done by inspectors, school administrators highlighted that: inspectors are experts at supervision, objective and they have full knowledge of the field and curriculum.

Some quotations which can be the examples to school administrators' expressions are given below:

"... They always follow the innovations, /they take positive education implementation from one place to another like bee taking pollens to the other flowers so it increases the motivation level of the teacher." (SA1)

"... Inspectors have full knowledge of the field and they are people who worked at different levels (as a teacher, school administrator etc), taken certain exams and passed them therefore they have their sufficiency. Since teachers consider inspectors as academically and hierarchically more valuable, course supervision should be done by inspectors." (SA2)

"... They remove subjectivity and bias form supervision. S/he conducts an objective, reliable supervision. With the tools like supervision guide, the validity and reliability of supervision get higher." (SA4)

"... I think that they are experts at supervising." (SA5, SA7)

"... It helps school administration. The fact that inspector will have the supervision enforces administrators against teachers.... It is like cleaning in detail for your guest coming to your home, when an inspector visits us, everything is thought in blow by blow." (SA6)

"... They have full knowledge of curriculum, they know the principles, rules and processes of supervision, and these are the advantages." (SA9) 
As for the advantages of having course supervisions done by inspectors, inspectors highlighted that: "they are experts at the field, experienced, objective, they have full knowledge of the field and curriculum, they are transferring model implementations from one place to another, they make teachers care about supervision, they have guiding and counseling roles, they can provide different outlook to institution and teachers, they are sufficient for teaching methods and techniques" As for the advantages of having course supervisions done by inspectors, inspectors highlighted that: they are experts at supervision, objective and they have full knowledge of the field and curriculum.

Some of the quotations which can be the examples to inspectors' expressions are given below:

“... First of all inspectors are trained in supervision. Objectivity is another advantage "... Teachers see the supervision more important when it is done by someone who is hierarchically higher. Position is effective." (14)

"... Since they are experts, teachers see them as authority. They are well accepted authorities. ... They have enough knowledge, experience and supervision sufficiency. They are perceived as reputable people by teachers." (15)

"Every inspector has full knowledge of curriculum of his/her branch. S/he can implement the teaching methods and techniques to his/her own branch. S/he can detect the problematic implementations. S/he can share the other positive implementations that $s /$ he experience from other institutions. S/he can implement scientific processes related to supervision." (I7)

".... Inspectors are people who are selected and expert at their own fields. They studied in the field and some of them have BA, MA and PhD degree and they are of course experienced..." (19)

It is seen that teachers, school administrators and inspectors are of a single mind about the matter. They state the positive sides as being objective, experts at supervision, having full knowledge of the field.

\section{The Negative Sides of Having Course supervisions done by Inspectors}

The codes and themes regarding the negative sides of having course supervisions done by inspectors are shown in Table 8. 
Table 8.

Reviews on the Negative Sides of Having Course supervisions done by Inspectors.

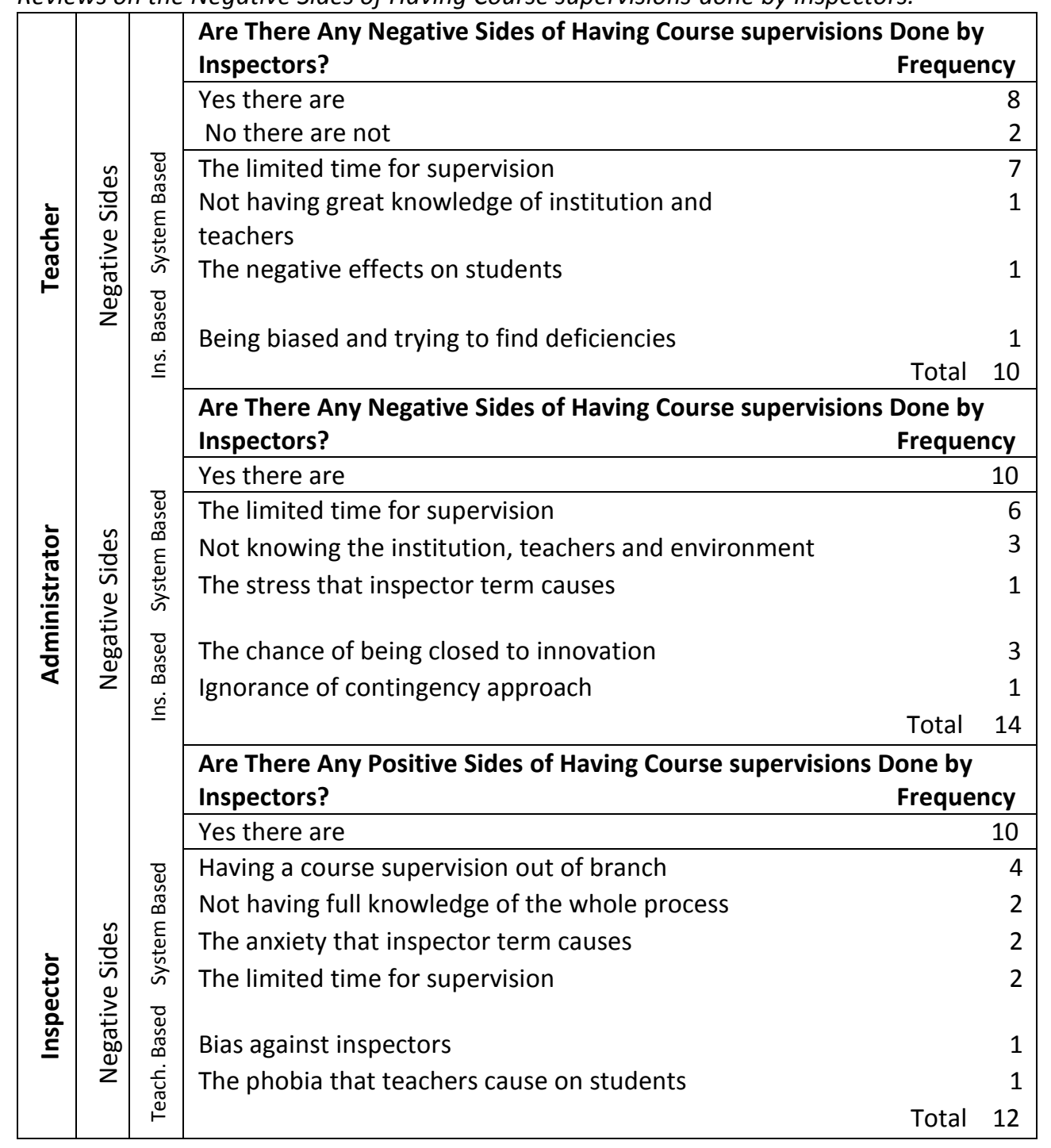

In Table 8, the data gathered as a result of the content analysis of the perceptions of study sample regarding the negative sides of having course supervisions done by inspectors are shown below:

Teachers' thoughts on the disadvantages of having supervision done by inspectors are investigated under two main themes as inspector based disadvantages and system based disadvantages. System based disadvantages are "the limited time for supervision, not knowing the institution and teachers, harmful effects on students when somebody outside the institution comes for supervision. Inspector based disadvantages are stated as "being biased and trying to find deficiencies". System based disadvantages are considered as the situations that are not directly related to the inspector herself. The only disadvantage stated by teachers about the disadvantage related to inspectors is that they are biased and trying to find deficiencies. This disadvantage is only stated by a teacher. (T10)

Some quotations which can be the examples to teachers' expressions are given below:

"... Having the supervision only in a limited time is a disadvantage." (T2)

"... Having supervision in 40-80 minutes is a disadvantage." (T3) 
“... I haven't seen any disadvantages I think they are experienced. Although the supervision is done in a limited time, many pros and cons of teacher can be detected during this time." (T5)

"... There are. And it is the time. Supervision done in one or two lesson hours is not enough. The performance of the students in the class just for an hour is not enough to show the whole effort that the teacher invests in during a year. I am teaching in nine different classes and there are significant differences among each class." (T7)

"... If the inspector is an expert and has no personal problems with teachers, there will not be any problems." (T8)

"... Since the time is limited, it hinders getting know the teacher If the inspector came multiple times in a year, s/he would observe the differences in a better way."(T10)

"... Bias against teachers and trying to find deficiencies of them are the negative sides. But this do not exceed \%20 of the situations I have experienced so far." (T11)

School administrators' thought on the disadvantages of having supervision done by inspectors are investigated under two main themes as inspector based disadvantages and system based disadvantages. System based disadvantages are stated as "the limited time for supervision, not knowing the institution, teachers and environment, the stress that inspector term causes. "Inspector based disadvantages are stated as "the chance of being closed to innovations and ignorance of contingency approach. It is seen that most of the disadvantages stated by school administrators are system related ones.

Some quotations which can be the examples to school administrators' expressions are given below:

"... It would be demotivating for a teacher to follow technological innovations and implementing them in his/her teaching strategy to have an inspector asking for old fashioned teaching strategies. So this will decrease the teaching quality." (SA2)

"... Since the supervision is for a limited time, there will not be enough chances to know the staff and evaluate the educational materials in detail." (SA3)

"... It is a disadvantage that inspectors ignore the contingency approach." (SA5)

"... I need to say that the whole things that the teachers have done in a year time cannot be seen in such a limited time." (SAT)

"... The stress caused by inspectors on teachers is another disadvantage." (SA8)

Inspectors' thought on the disadvantages of having supervision done by inspectors are investigated under two main themes as teacher based disadvantages and system based disadvantages. System based disadvantages are stated as " supervising an out of branch lesson, not having full knowledge of the whole learning and teaching process, the anxiety that inspector term causes, limited time for supervision. "Teacher based disadvantages are stated as "the phobia that teachers cause on students because of their bias against inspectors."

Some of the quotations which can be the examples to inspectors' expressions are given below:

“... Since inspectors are reflected as a fear factor to the students, teachers have negative thoughts on inspectors due to this reason." (I11)

"... There is less chance to obverse the whole education process. The formal conversations because the anxiety that teacher has because of talking to inspectors and not having chances to see the change in the institution and class from begging to end are the negative factors in supervision." (14).

"... There are only few disadvantages. And that is the anxiety that inspector term causes on teachers..." (I8)

Teachers, school administrators and inspectors have been determined to be a single mind about the matter. They state the negative sides as having supervision for limited time, not knowing the institution, teachers and environment, not having full knowledge of learning and teaching process. Participants have stated three codes about the inspector based disadvantages. These are the chance of being closed to innovations (3/10), ignorance the contingency approach $(1 / 10)$ and being biased and trying to find deficiencies $(1 / 10)$ 


\section{Requirement of Who or Who to Perform the Course Supervision}

The codes and themes regarding by whom the course supervision must be done are presented in Table 9.

Table 9.

Reviews on by whom the Course supervision must be done.

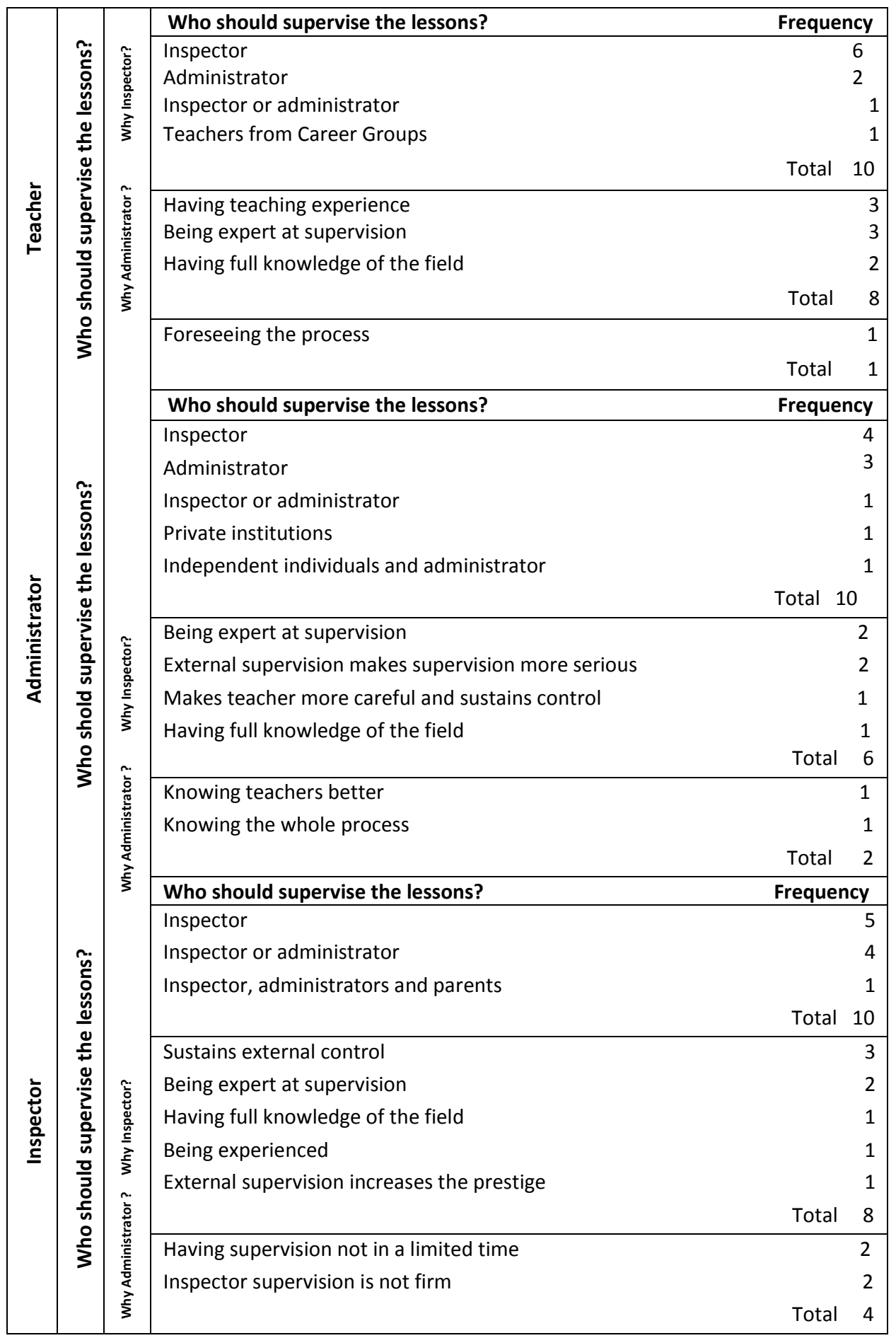


As it is seen in Table 9 for the question of the best option to have the supervision, teachers, school administrators and inspectors answered inspectors and administrators successively.

Teachers have mainly stated that inspectors are the most appropriate people to have the lesson supervision $(6 / 10)$ and then administrators $(2 / 10)$. When teachers are asked for the reasons for their statements they highlighted the reasons as having teaching experience, being expert at supervision and having full knowledge of the field. When it comes to administrators, teachers stated the reason as having the chance of seeing the process form beginning to end.

Some quotations which can be the examples to teachers' expressions are given below:

"... First of all s/he needs to have teaching experience, know the process that teacher's experience "Supervision must be done by expert inspectors who are from teaching field but not with the teacher title." (T2)

"... Inspectors should supervise the lessons on the condition of having the requirements for supervising otherwise it would be meaningless" (T3)

"... I think inspectors should supervise the lessons because I am of the opinion that they are guiding and counseling more and making constructive critics." (T5)

"... Administrators should do it Administrators must be sufficient for their fields and if they can be objective during supervision, I believe that it would be more beneficial." (T7)

"... I think administrators should do it. Because they have the chance of observing teachers for a long time and they know the students in the classes better. Supervision and teaching is a time taking process and it must constantly be observed." (T9)

"... Should be done by professional inspectors. Inspectors should visit the schools more often and know the teacher better Ignorance the contingency approach must be taken into consideration." (010)

School administrators have mainly stated that inspectors are the most appropriate people to have the lesson super vision $(4 / 10)$ and after that administrators (3/10) When school administrators are asked for the reasons for their statements they highlighted that inspectors are experts and they have full knowledge of the field, external supervision makes the process more serious and teachers more careful so it sustains control. When it comes to administrators, school administrators stated the reason as knowing teachers and the whole process form beginning to end.

Some quotations which can be the examples to school administrators' expressions are given below:

"... Inspectors are experienced and expert people at supervision. If such people supervise the lesson, this will bring a positive supervision process and so it will bring educational success. Moreover external supervision enables a more serious supervision... Since the teacher will be under control, s/he will do her/his job in a more careful way."(SA2)

"It should be done by the inspector but s/he needs to ask for the administrators options. The relation between teacher and administration is getting worse as the principle undertakes the supervisor role. Administrators must act like a communication bridge between inspector and teachers."(SA6)

"... I am of the opinion that supervision must be done by administrators who get enough education, have sufficient communication skills, and are brave leaders in education field."(SA8)

Inspectors have mainly stated that inspectors are the most appropriate people to have the lesson super vision (5/10) or in cooperation with school administrators (4/10). When inspectors are asked for the reasons for their statements they highlighted that inspectors sustain external supervision, external supervision improves the prestige, they have full knowledge of the field, they are experienced and expert at their jobs therefore supervision must be done by inspectors. Inspectors support the idea of having the supervision with the school administrators because of not being able to come to the institution often and not to have supervision in limited time.

Some quotations which can be the examples to inspectors' expressions are given below: 
“... Absolutely by inspectors. Course supervision must be done by inspectors who are experts at the branch." (I3)

"... Actually course supervision must be done both by inspectors and administrators. Supervision must not be done in a very limited time both inspectors and administrators supervise the lessons in different times Disadvantages of limited supervision by inspectors and inspectors' subjectiveness can be avoided in this way." (14)

"... Inspectors should supervise the lesson. Because they are experts and since they come out of the institution they have got prestige moreover since they see different implementations at different schools they are more experienced. On the contrary, school administrators only know the school they are working." (15)

"... Inspectors should do the course supervisions regularly more than one in a year. Apart from the time in which inspector supervise the lessons, school administrators have the chance of constant observation since they are always at school.

\section{Results, Discussion and Recommendations}

\section{The Need for Course Supervision}

It was stated by the teachers, school administrators and inspectors that having course supervision is necessary. As taking a direct role in the supervision process, teachers, school administrators and inspectors perceive course supervision as an institutional necessity. As a result of the study, which was participated by teachers, school administrators, inspectors and teaching staff at universities, Memduhoğlu (2012) shows that the necessity of the course supervision is highlighted by most of the participants in the study. Özbaş (2002) also reveals that teachers and school administrators are of the opinion that in-class activities should be supervised in every aspect. However in Altun's (2014) study, supervisors reflect the idea that the frequency of the supervision must be increased whereas the people who are supervised support that the frequency should be decreased or course supervisions should be abolished. Teachers and inspectors expressed that ideal supervision would only take place if the teacher and the inspector were to do so with more business cooperation (Rizzo 2004).Course supervision helps teacher in teaching and curriculum development processes (Glickman, Gordon \& Ross, 2004). Course supervision, which is a need for teachers (Acheson \& Gall, 2011), is also a milestone for a successful school; besides it is glue that is needed for a successful school (Glickman, 1990).Acar (2009) stated that school administrators find course supervision beneficial for their professional development and they also state that if it is well-conducted, it can also have positive contributions to school, teachers and school administrators. In this perspective, educational supervision, more specifically, course supervision, can be regarded as an institutional necessity.

As a result of the study, it is possible to present the necessity of course supervision in terms of two different aspects, personal and institutional. The reasons which make course supervision a personal necessity can be listed as, tracking and determining the performance level of teachers, having positive contribution to their professional development, sustaining their motivation and self-esteem and checking to what extent they follow the given curriculum. Teachers, school administrators and inspectors especially highlight the importance of course supervision in terms of showing the performance of teachers. The function of course supervision in showing teachers' performance is supported by the related literature. Köklü (1996) states that supervision is the only way to reveal if there is an effective operation to fulfill the goals of the educational system or to determine the required regulations to reach them. Multi-dimensional development of teachers, strengthening their weaknesses and sustaining their professional development are among the functions of course supervision. (Gündüz, 2012). Checking if teachers have achieved their given missions, determining their difficulties in reaching them and making required regulations to overcome the difficulties are only possible by means of scientific measuring methods and supervision (Altun, 2014). Course supervision tries to decrease the 
chance of making mistakes to minimum by guiding teachers. Therefore, it essentially aims to increase the motivation and performance of teachers (Aslanargun\& Göksoy, 2013).

The reasons which make course supervision an institutional necessity can be listed as determining working and inactive teachers, sustaining the effective management in institution, determining mistakes and making required regulations for them and revealing the level of reaching the educational goals. In terms of the participants, distinguishing the active teachers, who make some effort to reach teaching goals, from the inactive ones is important. Therefore, they see course supervision as a necessary tool to reveal this fact. Assessing the quality of educational activities is seen as a necessity. In order for the assessment and effective management, it is stated that supervision is necessary. In addition to checking to what extent the institutional goals have been reached and training educational staff, educational supervision aims to reveal if human resources department, which is the most important department at a school, is well-managed or not (Demirtaş, 2010).

It is an individual and organizational necessity to bring the supervisory issues to the foreground with minimal administrative and political considerations, which reveals that many educational stakeholders, from teachers to school administrators and inspectors, are ignored (Hsieh \& Shen, 1998). The results of the study show that teachers, school administrators and inspectors perceive supervision as a personal and institutional necessity. For this reason, supervision is a necessity and it is the first step of taking preventive and regulative actions (Bursalıoğlu, 2002).

\section{Course supervision as a Specialization-Required Area}

The results of the study indicate that teachers, school administrators and inspectors perceive course supervision as a specialization-required area. The reasons for the former statement are given as the one who is responsible for supervision must have full knowledge of the field (curriculum, implementation process, method and techniques), be sufficient in human relations and communication, have professional experience ( knowledge of teaching, pedagogical formation and world knowledge). Moreover, it is an undeniable fact that supervision is a discipline which has its own principles, rules and procedures. The supervisor must be aware of these principles and rules. As for the given result, Taymaz (2005) also state that inspectors must have the required technical, humanistic and decision making skills. Aslanargun \& Tarku (2014) also support this claim by stating that inspectors must have sufficient skills for giving constructive feedback and guiding teachers. Inspectors are role models for the ones who are supervised and they are the ones who can increase the quality of supervisions to the sufficient levels (Gündüz ve Göker, 2014). A supervisor, who is responsible for the supervision of a lesson, must theoretically and practically be aware of its curriculum and its contributions to the students, teaching methods, techniques, classroom management, student behaviors and development process. Since each of these fields can be stated as a specialization-required area, it is clearly observed that course supervision is a specialization-required area.

\section{Specialization of Administrators on Course supervision}

Teachers, school administrators and inspectors are of the opinion that school administrators are not experts at course supervision. It is noteworthy that administrators do not perceive themselves as experts at course supervision. As for the reason why administrators are not experts at course supervision, the mostly stated reasons are not having supervision formation or their insufficiency in this regard, not being objective in the evaluation process and not having full knowledge of the curriculum. It is seen that teachers, school administrators and inspectors are of a single mind about the matter. Aslanargun \& Göksoy (2013) also state that teachers have worries about the objectivity of supervision when it is done by principles. Moreover, Acar (2009) indicates that although administrators perceive course supervision as a guiding and supportive tool, they do not reflect these matters during the supervision process. Therefore, teachers are of the opinion that course supervisions done by the administrators are not purposeful and teachers perceive course supervision as an assailant tool for sustaining control. Consequently, a supervisor must have supervision formation, be objective in the 
evaluation process and have full knowledge of the curriculum; however, school administrators are not perceived as competent.

\section{The Positive Sides of Having Course Supervisions Done by School Administrators}

Knowing the staff, environment and institution in a better way and having full knowledge of the whole learning and teaching process are the positive results of the study for having course supervision by administrators. Teachers, school administrators and inspectors mainly explain the positive sides of having course supervision by school administrators as knowing the staff and institution in a better way, chance of having constant observation. Altun (2014) supports this claim by stating that teachers mainly want school administrators, vice administrators and group leaders as their lesson supervisors. Aslanargun \& Göksoy (2013) also state that teachers prefer course supervision which is done by school administrators depending on the reason that administrators have a chance of constant and closer observation.

\section{The Negative Sides of Having Course Supervisions Done by School Administrators}

The research findings have revealed the disadvantages of supervisions done by school administrators as not being objective in the evaluation process, insufficiency of their supervision formations, not having full knowledge in the field, knowing each other's deficiencies as supervisors and people being supervised, using supervision as a pressure tool, deterioration of the institutional structure at the end of the supervision, being biased during the supervision, having conflict among administratorteacher/ teacher-teacher at the end of the supervision, teachers' efforts for having good relationship with the school administrators in order to get better scoring, keeping administrators under pressure during the decision process, the problem of making the supervision process less serious and its negative effects on teachers. Having conflict among administrator-teacher/ teacher-teacher at the end of the supervision is highlighted as another negative aspect. It worths mentioning that school administrators have made more negative comments on course supervisions, which are done by the administrators, than teachers and inspectors. When it is compared to few positive statements about course supervisions, which are conducted by school administrators, it is clear to see that most of the statements are negative about the issue.

When the related literature, which aims to find out the positive and negative aspects of having course supervision done by school administrators, have been examined, some of the studies have parallel and some of them have different results from the current study. Demir and Tok (2015) stated that school administrators' perceptions regarding environmental conditions and teachers' better understanding of the researches they conducted were positive for school administrators. Aslanargun \& Göksoy (2013) state that course supervisions which are done by the school administrators are lack of reliability in terms of objectivity. However, they also state that it might prevent course supervision from being result-oriented and only paper based. YIlmaz (2009) reveals the positive sides of having course supervisions done by the administrators as, administrators know the teachers better than the inspectors, they know teachers' weak and strong points, and they are also informed about all of the activities that teachers do. Moreover, administrators also know what the teachers do in their free times outside the classroom and by administrator supervisions, the longtime intervals between the supervisions can be prevented. The results of the current study about course supervisions, done by the administrators, support the aforementioned study.

\section{The Positive Sides of Having Course Supervisions Done by Inspectors}

According to the results of the study, course supervision done by inspectors is more preferable than course supervision done by administrators. Teachers, school administrators state the positive sides of course supervisions done by inspectors as: inspectors are objective in evaluation and supervision, they have full knowledge of the field, they are able to guide and counsel teachers, they can provide different outlook to institution and teachers, they are experienced and professional, they are effective at 
supervision, the effect of inspector term reflect on the teaching and training process in a positive way, they transfer model implementations from one place to another, they make teachers care about supervision, they are sufficient for teaching methods and techniques, they are aware of the contemporary innovations in education field, they prevent the possible conflicts at the end of the supervision. Akşit (2006) is of the opinion that course supervisions must be done once in several years by inspectors in terms of objectivity, but administrators should conduct course supervisions every year. Demir \& Tok (2015) have revealed that teachers perceive course supervisions done by inspectors as objective and teachers believe their expertise in their fields. Demirtaş \& Akarsu (2016) state the positive sides of course supervisions which are done by inspectors as forcing teachers to get ready for the supervision, treating their jobs seriously, having the supervision in an objective, fair and equal way, increasing the education quality, guiding teachers and transferring the innovations in teaching to the teachers in a fast and correct way.

\section{The Negative Sides of Having Course Supervisions Done by Inspectors}

However the negative sides in the same study are classified as system, teacher and inspector based negative sides. System based negative sides are the negative aspects which cannot be controlled by supervisor. System based disadvantages/negative sides are having supervision for limited time, not knowing the institution, teachers and environment, not having full knowledge of learning and teaching process, the phobia that the inspector term causes on teachers and students and supervising an out of branch lesson. Teacher based disadvantages are stated as the phobia that teachers cause on students because of their bias against inspectors. For the inspector based disadvantages, most of the teachers, school administrators and administrators do not mention any negative aspects. Only one teacher in the study sample stated that inspectors are biased and they try to find the weak points of the teachers and one school administrator stated that inspectors ignore the contingency approach and they do not have chances to follow the innovations in the field, as the negative sides. Therefore, the study has revealed that the negative sides of course supervisions which are done by the inspectors, are mainly related with non-inspector reasons. In parallel to this result, Demirtaş \& Aksu (2006) show the disadvantages of supervisions done by the inspectors as meeting teachers only once in a year, checking only the documents instead of supervising the lessons, acting partially, supervising an out of branch lesson, supervising lessons to satisfy their egos, the stress and disturbance of having an unknown person in the classroom. Both of the studies show similar results that the disadvantages / negative sides of course supervisions done by inspectors are system, teacher and inspector based. When the relevant literature have been analyzed, the results of the study on the positive and negative sides of course supervision done by the inspectors show similarity with the retrospective studies. Both positive and negative sides of course supervisions done by the inspectors are available, but most of the negative sides depend on non-inspector based reasons.

\section{By Whom the Course supervision must be done}

For the question of the best option to have the supervision, participants mostly stated that inspectors are the best option for supervising the lessons. Having teaching experience, being experts at supervision, having full knowledge of the field, treating their jobs seriously, increasing teachers' attention to their lessons and the ability to control the teacher are the reasons for the statement that inspectors are the best options for the course supervision. In the study conducted by Rosenfeld, Giacalone and Riordan (1995), teachers are of the view that the most effective participation process can take place with the inspectors. Participants stating that course supervisions must be done by the administrators give its reason as inspectors cannot often visit the institution, administrators have full knowledge of teaching and learning process and they know the teachers in a better way.

The results of the current study highlight that course supervision must be done by inspectors. After inspectors, participants respectively prefer administrators, inspector-administrators, parents-teachers and private institutions to conduct course supervisions. 
When different studies have been analyzed to find out who is the best option to have the supervision, different results have been obtained from different studies. Demir \& Tok (2015) support that teachers prefer inspectors for course supervision because they are objective and experts at their fields but they also prefer school administrators because they know environment, institution and teachers better than inspectors. Gündüz, Aslan \& Bozkuş (2015) state that school administrators must fulfill their duties of supervising, guiding teachers and sustaining their professional development. Okutan (2015) has found out that teachers and school administrators have positive attitudes towards course supervisions done by the administrators, however, inspectors are of the opinion that course supervisions should not be conducted by the administrators. Demirtaş \& Akarsu (2016) have noted that teachers do not have positive attitudes towards course supervisions done by inspectors. Despite some worries, teachers have positive attitudes towards course supervisions done by the administrators. Aslanargun \& Göksoy (2013) support this statement with its results revealing that despite the concern of objectivity, teachers prefer having course supervisions done by the administrators depending on the reason that they can supervise the process and performance in a closer way. The results of Yıldız, Akbaşlı \& Üredi's study (2015) show that primary and middle school teachers have positive attitudes towards lessons supervisions done by the administrators and they find their guidance and supervision effective and necessary. According to Altun (2014) teachers respectively prefer school administrator, vice administrator, group leader and inspectors to conduct course supervisions. Yılmaz (2009) supports this claim by stating that it is more appropriate to conduct course supervisions by administrators. According to Topçu (2010) both school administrators and most of the teachers think that administrators are the best choice for supervising in-class activities and assessing teachers. However Alay (2006) highlights that teachers find traditional supervision insufficient, they have negative thoughts on having supervisions done only by administrators and inspectors. Başol (2009) has concluded that teachers would rather supervisions which are conducted by administrators than inspectors. Akbaba \& Memişoğlu state that most of the teachers are of the opinion that school administrators must take an active role in the supervision process, however, some of the teachers are worried about subjectivity and therefore they do not have positive attitudes towards it. As it can be seen from the different study results, although there are different answers to the question of the executers of the course supervision, the mostly stated answers are inspectors or school administrators.

\section{Recommendations}

1. As a result of the study, teachers, school administrators and inspectors are of a single mind about the necessity of course supervision and it is also a necessity in terms of personal and institutional perspective. Therefore, course supervisions must be kept in order to determine and increase the quality of educational services.

2. The results also indicate that course supervision is a specialization-required area. Since course supervision is a specialization-required area, supervisors must be experts at their fields to conduct course supervision. In order to obtain the required expertise, supervisors can be trained during inservice trainings and courses.

3. The results of the study show that course supervisions should mostly be conducted by inspectors. In line with this result, inspectors may be given more active roles in the course supervision process which is conducted by school administrators according to current regulations. In this way, school administrators and teachers can benefit from inspectors' expertise effectively, thanks to it the quality of supervision process can be improved. Moreover, administrators can take an active role during the supervision process with inspectors.

4. The results of the study indicate that teachers, school administrators and inspectors are of the opinion that administrators are not the experts at course supervisions. It is noteworthy that school administrators find school administrators insufficient for the supervision process. As for the reason why administrators are not experts at course supervision, the mostly stated reasons are not having 
supervision formation or their insufficiency in this regard, not being objective in the evaluation process and not having full knowledge of the curriculum. Knowing the staff, environment and institution in a better way and having full knowledge of the whole learning and teaching process are the positive results of the study for having a course supervision by administrators Taking these positive and negative situations into consideration, it is possible to have an external supervision which is conducted by inspectors with the active participation of school administrators instead of conducting the supervision just by the administrators. In this way, the negative aspects of having course supervision done by the administrators may be released and its positive contributions may be benefited during the process.

5. As long as the supervision is done by the school administrators, it must be critical to evaluate candidate administrators' supervision skills during administrator election process.

6. The study reveals that both the number of the supervision conducted in a year and supervision time are not adequate. It is possible to increase the number and the time of the supervision; therefore, it is possible for inspectors to know teachers, institution and its environment in a better way.

7. Ministry of National Education may ask for opinions on the best choice to conduct course supervisions, implement pilot schemes and evaluate its results accordingly, then create a new supervision implementation.

8. This study explores the attitudes and ideas of teachers, school administrators and inspectors on course supervision. For the future studies, students, parents and other education partners may be asked for their ideas.

9. Different studies which investigate the different course supervision implementations may be conducted and different course supervision implementations may be compared. 


\section{Türkçe Sürümü}

\section{Giriş}

Eğitim sistemleri, insanlar için ve yine insanlarla üretimi gerçekleştirdiklerinden insan unsurunun en çok yer aldığı sistemlerdir. En önemli girdileri insan olup ürünleri ise istendik davranışlardır. Bu bakımdan eğitim sistemlerini insandan ayrı düşünmek mümkün değildir. Bu yönüyle eğitim tarihinin, insanlık tarihi ile başladığı, insanlık tarihinin gelişimine paralel olarak gelişim sergilediği ve aynı zamanda bu tarihi geliştirdiği ifade edilebilir. Tarihi, insanlık tarihi kadar eski olan eğitimin gelişim süreci irdelendiğinde eğitimin kurumsallaşmasının 18. yüzyılın ikinci yarısından sonra başladığı görülmektedir. Halen devam eden bu kurumsallaşma sürecinin günümüze kadarki seyri incelendiğinde sürekli bir değişimin varlığı göze çarpmaktadır. Bu değişim, insan ve eğitim var oldukça var olacak bir süreçtir.

Eğitimin kurumsallaşma sürecinde denetimin her zaman eğitimin yanında var olduğu görülmektedir. Türk eğitim tarihine bakıldığında maarif teşkilatının kuruluşuna doğru atılmış ilk adım olan 1846 yılında Mekatib-i Umumiye Nezaretinin kurulmasının ardından 1847'de "Sıbyan Mekatibi Hocaları Efendilerine İfa Olunacak Talimat" adlı yönetmelikle ilkokullar müfettişliğinden (muin) bahsedilmiştir (Buluç, 1997). 1862 yılında ilk defa teftiş ve müfettiş kavramlarına yer verilmiş, 1869 tarihli Maarif-i Umumiye Nizamnamesinde denetim görevi eğitim teşkilatının Resmî görevleri arasında yer almıştır. 1914 yılında yayımlanan bir talimatname ile genel ve özel okulların teftişine ilişkin esaslar belirlenmiştir. Cumhuriyet dönemine gelindiğinde Türkiye Cumhuriyeti'nin kurulduğu tarih olan 1923'demüfettişlerin görevlerine ilişkin yönetmelik ve akabinde müfettişlerin görevlerine ilişkin bir talimatname yayınlanmış, 1931 yılında da müfettişlik merkez ve taşra diye ikiye ayrılmış, daha sonra tekrar vekâlet müfettişliği adı altında birleştirilmiştir. 1933 yılında Teftiş Kurulu Başkanlığı oluşturulmuş, 1938 yılında ise müfettiş olacaklarda Gazi Terbiye Enstitüsü mezunu olma şartı aranmıştır.

Yakın geçmişe bakıldığında 1990 yılında Millî Eğitim Bakanlığı illköğretim Müfettişleri Kurulu Yönetmeliği ile mesleğe alım şartları, görev alanları düzenlenmiş (MEB, 1990), 1999 yılında MEB İlköğretim Müfettişleri Başkanlıkları Yönetmeliği ile mesleğe alım esasları, görev alanları, çalışma bölgeleri, hizmet süreleri yeniden düzenlenmiştir (MEB, 1999). 24/06/2011tarihinde yayımlanan MEB Eğitim Müfettişleri Başkanlıkları Yönetmeliği ile ilköğretim müfettişliği ismi eğitim müfettişliği olarak değiştirilmiş, bu yönetmelikle ilköğretim müfettişlerinin mevcut teftiş, rehberlik, inceleme, araştırma, soruşturma görevlerine ortaöğretim kurumlarının denetim, rehberlik, inceleme ve soruşturma görevleri eklenmiştir (MEB, 2011).Bununla birlikte ortaöğretim kurumlarının teftiş edilmesi, bu kurumlarda rehberlik yapılması, ortaöğretim kurumlarında çalışan öğretmenlerin ders yeterlilikleri ile ilgili inceleme ve soruşturma görevleri hariç olmak üzere bu kurumlarda çalışan bütün personelin inceleme ve soruşturma görevlerinin taşrada bulunan eğitim müfettişleri tarafından yapılması sağlanmıştır.

14/09/2011 tarihli ve 28054 sayılı Resmî Gazetede yayımlanan 652 Sayılı Millî Eğitim Bakanlığının Teşkilat ve Görevleri Hakkında Kanun Hükmünde Kararname ile taşrada görev yapan eğitim müfettişlerinin görev unvanları il eğitim denetmeni, merkezde görev yapan bakanlık müfettişlerinin görev unvanları ise bakanlık denetçisi olarak değiştirilmiştir (Resmî Gazete, 2011). 24/05/2014 tarihli ve 29009 tarihli Resmî Gazete' de yayımlanan Rehberlik ve Denetim Başkanlı̆̆ı ile Maarif Müfettişleri Başkanlıkları Yönetmeliği ile birlikte bir önceki yönetmelik olan ve il eğitim denetmenlerinin/bakanlık denetçilerinin tabi olduğu 24/06/2011 tarihli MEB Eğitim Müfettişleri Başkanlıkları Yönetmeliği yürürlükten kaldııımış, bakanlık denetçileri ile illerde görevli il eğitim denetmenleri maarif müfettişi adı altında birleştirilmiştir(MEB, 2014). Bu değişiklikle birlikte denetim hizmetleri, Bakanlığın görev alanına giren konularda Bakanlığın merkez, taşra ve yurt dışı teşkilatlarını kapsar duruma getirilmiş, eğitim kurumlarının denetiminde ders denetimi uygulaması kaldırılmış, denetim çalışmaları kurum denetimi şeklinde yürütülmeye başlanmıştır. 
09/12/2016 tarihli ve 29913 sayılı Resmî Gazetede yayımlanan 6764 Sayılı MEB Teşkilat ve Görevleri Hakkındaki KHK ile Bazı Kanun ve KHK'larda Değişiklik Yapılmasına Dair Kanun ile birlikte MEB merkez teşkilatındaki Rehberlik ve Denetim Başkanlığı ibaresi Teftiş Kurulu Başkanlığı, maarif müfettişleri ibaresi de bakanlık maarif müfettişi ibaresi şeklinde değiştirilmiştir (Resmî Gazete, 2016).Bu kanunla birlikte bakanlık maarif müfettişi olacaklarda aranan şartlar 657 Sayılı Devlet Memurları Kanunundaki genel şartlara ilaveten en az dört yıllık eğitim veren hukuk, siyasal bilgiler, iktisadi ve idari bilimler, iktisat, işletme fakülteleri ve dengi yurt içi, yurt dışı yükseköğretim kurumlarından mezun olmak ve yapılacak yarışma sınavından başarılı olmak şartı getirilerek yeniden düzenlenmiştir.

Rehberlik ve Denetim Başkanlığı kadrolarında görevli olan personelin görevleri 6764 sayılı kanunla birlikte sona ermiş, maarif müfettişleri il Millî eğitim müdürlerine bağı olarak inceleme, araştırma ve rehberlik hizmetleri ile il Millî eğitim müdürünün vereceği diğer görevleri yapacak şekilde görev alanları belirlenmiş, illerde görev yapan maarif müfettişlerinin denetim ve soruşturma görevleri bu kanunla birlikte sona ermiştir. Yine bu kanunla birlikte maarif müfettişleri başkanlıklarında görevli maarif müfettişlerinin kadroları şahsa bağlı kadro haline getirilmiş, herhangi bir sebeple boşalması halinde bu kadroların iptal olacağı kanun maddesi ile düzenlenmiş, bakanlık merkez teşkilatında 500 adet bakanlık müfettişi kadrosu ile 250 adet bakanlık müfettiş yardımcısı kadrosu indas edilmiştir.6764 sayılı kanunla birlikte Teftiş Kurulu Başkanlığının ve çalışma merkezlerinin görev, yetki ve sorumlulukları, çalışma usul ve esasları, bakanlık maarif müfettişlerinin ve bakanlık maarif müfettiş yardımcılarının görev, yetki ve sorumlulukları, mesleğe alınmaları, yetiştirilmeleri, yeterlikleri, yükselmeleri, görevlendirilmeleri, çalışma merkezlerine dağılımları, merkezler arasında yer değiştirmeleri ve diğer hususların yönetmelikle düzenleneceği ilgili kanunun 6/4 maddesinde ifade edilmiştir.

Türk eğitim sisteminin denetim alt sisteminde yapılan bu son değişiklik ile birlikte illerde kalacak maarif müfettişlerinin denetim görevlerinin olmayacağı görülmektedir. Bakanlık merkez teşkilatında bulundurulacak olan 500 maarif müfettişi ve 250 maarif müfettiş yardımcısı ile eğitim sistemindeki bütün kurumların ve çalışanların denetiminin yapılması mümkün görülmemektedir. Ayrıca bakanlık maarif müfettişi kadrolarına yeni atanacaklarda aranacak şartlara bakıldığında bunlardan öğretmen olabilme, öğretmen olma şartını taşıma ya da eğitim fakültesi çıkışlı olma şartı aranmamaktadır. Bu itibarla uygulanacak olan denetimlerin ders denetimlerinden ziyade kurum denetimi olacağı ve kurum denetimlerinin de idari ve mali denetim ağırlıklı olacağı ifade edilebilir. Ancak denetimin nasıl olacağına ve neleri kapsayacağına ilişkin olarak 6764 Sayılı Kanun'u takiben yayımlanacak olan yönetmelikle birlikte açıklık getirebilecektir.

Özellikle son yıllarda denetim alt sisteminde hızlı bir değişimin olduğu bilinmektedir. İlköğretim müfettişliği, eğitim müfettişliği, il eğitim denetmenliği/bakanlık denetçiliği, maarif müfettişliği, bakanlık maarif müfettişliği şeklinde görülen yapısal değişimlerle birlikte birtakım işlevsel değişimlerin de olduğu görülmektedir. Bu durum denetim sistemine ilişkin bir arayış içerisinde olunduğunu ortaya koymaktadır. Yaşanan bu değişimler aslında denetim alt sisteminin varlığına ilişkin bir tartışma değil denetimin yapısının ve işlevinin nasıl olması gerektiğine ilişkin tartışmaları içeren bir süreçtir. Bu açıdan bakıldığında denetim alt sisteminin eğitim sistemi açısından gerekli olduğu açıktır. Türk eğitim tarihi açısından bakıldığında, eğitim teşkilatlanmalarında sürekli olarak bir denetim mekanizmasının varlığı bu ihtiyacı göz önüne sermektedir. Bu yönüyle denetimin, eğitimin vazgeçilmez bir parçası olduğunu ifade etmek yerinde olacaktır.

Denetimin, eğitimin vazgeçilmez bir parçası olması, denetimin okulun amaçlarına uygun çalışıp çalışmadığını ortaya koyması, belli ilkeler doğrultusunda ve profesyonel bir bakış açısıyla okulun amaçlarına uygun yaşatılması için işlev görmesi rolünden kaynaklanmaktadır. Denetim, okulun var olma sebebine uygun bir yaşam sürüp sürmediğini ortaya koyar. Özelde öğretmenin, sınıfın ve okulun, genelde ise eğitim sisteminin amaçlarını gerçekleştirmedeki işlevselliklerini tespit ederek değerlendirir. Kişi ve kurumlara bu noktada rehberlik yaparak öneriler getirir. Kurum ve çalışanların etkililik ve verimliliklerini ortaya koyan denetim, eğitim disiplini ve yönetim disiplinindeki gelişim ve değişime paralel olarak gelişim ve değişim göstermiştir. Süreç içerisinde yapılan denetim tanımlamalarına 
bakıldığında bu farklılaşma göze çarpmaktadır. Geleneksel yaklaşımda denetimin sonuca odaklanan ve kontrol amaçlı olan bir süreç olduğu anlayışı günümüzde kişi ve kurumların gelişimlerine rehberlik etme, önleyici rehberlikle birlikte olası problemleri ortaya çıkmadan engelleme gibi daha çağdaş bir anlayışa evrilmiştir. Bundan dolayı yeni denetim modelleri de sadece var olan durumu tespit etmekten öteye geçerek öğretmenlere öğrenme yoluyla rehberlik edilmesi anlayışını benimsemişlerdir (Chamberlin, 2000).

Denetim artık bireylerin bilgi eksikliklerini gidermek, olumlu yönlerini geliştirmek, onlara yol göstermek gibi gerekçelerle yapılmaktadır. Bu anlamda öğrenci başarısının iyileştirilmesi için öğretmene yardım etmede aracılık yapan bir işleve sahiptir (Yılmaz, 2009).Denetimin bu işlevi çağdaş yönetim anlayışlarına göre de bir gereklilik olarak görülmekte, denetlenmeyen bir yönetsel sürecin verimlilik ve etkililiğinin sağlanması ve kendisini sürekli yenilemesi olanaklı görülmemektedir (Ağaoğlu, 2010). Çünkü her karmaşık örgütte var olan denetim, örgütsel ve yönetimsel bir zorunluluktur (Memişoğlu, 2012).

Denetim, kamu yararı adına davranışı kontrol etme yöntemidir (Bursalıoğlu, 2012). Denetim, genel bir ifadeyle örgütsel eylemlerin kabul edilen amaçlar doğrultusunda saptanan ilke ve kurallara uygun olup olmadığının anlaşılması sürecidir (Aydın, 2000). Bir başka tanımlamaya göre denetim, örgütsel amaçların gerçekleşme derecesini saptamanın yanında saptanan bu derecenin değerlendirilmesini, düzeltilmesini ve geliştirilmesini de kapsayan bir süreçtir (Gökçe, 1994). Denetim; inceleme, irdeleme, kontrol etme olarak da tanımlanmakta, amaçlı, kasıtlı ve öğrenci başarısını ve gelişimini daima merkeze alan ve buna uygun eğitsel planlar gerçekleştirilmesini ön gören bir etkinlik olarak görülmektedir (Badiali, Firth \& Payak, 1997; Glanz, Sullivan\&Shulman, 2007). Denetim, aynı zamanda yönetsel eylem, öğretim programları, insan ilişkileri, yöneticilik ve liderlik kavramları ile ilişkili olan eylemler bütünüdür (Wiles\&Bondi, 2000).

Eğitim denetiminde öncelikli amaç öğretmenlerin mesleki olarak yetişmelerine katkıda bulunmak, onlara rehberlik etmek ve bunun sonucunda eğitimdeki başarı düzeyinin artmasını sağlamaktır (Erdem \&Eroğul, 2012 a). Öğrenci başarısının artırılmasının yanı sıra öğretmenin öğretimsel ve eğitsel becerilerini geliştirmek denetimin diğer amaçları arasında yer almaktadır (Marzano, Frontier\&Livingston, 2011). Bu açıdan bakıldığında eğitimde ve okul sisteminde denetimin gereğine ve önemine olan inanç birçok yazar tarafından vurgulanmakta ve özellikle sınıf içindeki öğretimin denetimi kaçınılmaz görülmektedir (Aydın, 2005).

Eğitim sisteminde yapılan denetim ve değerlendirme, alanına göre kurum ve ders denetimi olmak üzere iki grupta incelenir. Ders denetimi, bir eğitim kurumunda öğretici olarak görev alan öğretmenlerin öğretim ve eğitim etkinliklerindeki çalışmalarının gözlenmesi, incelenmesi ve değerlendirilmesidir (Taymaz, 2005).Öğretmene ve okul yönetimine öğretim faaliyetlerinin uygulanmasındaki başarıya dair somut veriler sunması bakımından ders denetimlerinin önem taşıdığı ifade edilebilir. Öğretim sürecinde çalışıp olumlu ürünler ortaya koyan öğretmenin olumlu yönlerini yine öğretmenin kendisiyle paylaşmak, eksik yönleri ile ilgili öğretmeni bilgilendirmek, daha iyisini yapabilmesi için öğretmeni teşvik etmek, öğretimde birliği sağlamak, öğretmenlerin uyguladıkları öğretim metotlarını geliştirmek, öğretim araçlarının sağlanması ve uygulanmasında öğretmenlere yardımcı olmak, öğrenci başarısının bilimsel yöntemlerle ölçülmesi ve değerlendirilmesinde ve öğretmenlerin karşılaştıkları sorunların çözümünde öğretmenlere yol göstermek ders denetiminin amaçlarını oluşturmaktadır (Taymaz, 2005).Ancak amacı doğrultusunda yapılacak ders denetimleri işlevsel olacak, eğitim ve öğretim faaliyetlerinin niteliğine katkı sunacaktır.

Okulun eğitsel ve öğretimsel amaçlarının gerçekleştirilme düzeyinibulmak için öğrencilerin öğrenmedeki başarısını ölçmek gerekmektedir. Okul yönetimleri başarılı öğrencilerin sayısını ne kadar arttırmış ise eğitsel amaçları o denli gerçekleştirmiş sayılırlar. Bu yüzden denetleme süreci, okulda öğrenmeyi ve öğretmeyi etkileyen değişkenlerin neler olduğunu, bunların eğitim sürecinihangi miktarda etkilediğini ortaya çıkarmalı ve bu konudaki sorunları çözebilmelidir (Başaran, 1996).Bu yönüyle ders 
denetimi, okullarda etkili öğrenme ortamlarının oluşturulmasında etkililiği ve verimliliği arttıran bir unsur olarak değerlendirilmektedir (Sergiovanni \& Starrat, 2002).

$\mathrm{Bu}$ öneminden dolayı alan yazında ders denetiminin gerekliliğine ilişkin yapılan birçok araştırmaya rastlanmaktadır. Yapılan araştırma sonuçları genel olarak denetimin, yönetimin konusu olan her alanda ve yönetimin bütün süreçlerinde kendisini etkili bir şekilde hissettiren bir araç olduğunu, örgütsel eylemlerin kabul edilen amaçlar doğrultusunda saptanan ilke ve kurallara uygun olup olmadığııın denetimle anlaşılabileceğini, öğrencilerin başarısını artırmak amacıyla okullara denetim aracılığıyla yardım edilebileceğini bu bakımdan özellikle sınıf içindeki öğretimin denetiminin kaçınılmaz olduğunu ortaya koymaktadır (Aydın, 2000; Aydın, 2005; Erdem \& Eroğul, 2012 b; Sergiovanni \& Starrat 2002).

Türk eğitim sistemi açısından da önemli bir yeri bulunan denetim alt sisteminde yapısal ve işlevsel değişimler eğitim sistemimizin güncel tartışma konuları arasında yer almaktadır. Hâlihazırdaki uygulama ile ders denetimleri okul müdürleri tarafından yürütülmektedir. Başta denetime muhatap olan öğretmenler olmak üzere, okul idarecileri, müfettişler ve diğer eğitim paydaşları arasında bu uygulama üzerine tartışmalar devam etmektedir. Türkiye'de denetimin tartışıldığı bu süreç "Ders denetimi yapılmalı mıdır? Yapılmalı ise kim tarafından yapılmalıdır?" problemine yanıt aranmasını gerekli kılmaktadır.

Araştırmanın Amacı

Bu araştırmanın genel amacı ders denetimlerinin gerekliliğine ve gerekliyse kimler tarafından yapılması gerektiğine ilişkin öğretmenlerin, okul idarecilerinin ve maarif müfettişlerinin görüşlerini ortaya koymaktır. Bu amaçla aşağıdaki sorulara cevap aranmıştır:

1.Ders denetimlerinin gerekliliğine ve ders denetimlerinin uzmanlık gerektirip gerektirmediğine ilişkin öğretmen, okul idarecileri ve maarif müfettişlerinin görüşleri nelerdir?

2.Ders denetimlerinin okul müdürleri tarafından yapılmasının olumlu ve olumsuz yönlerine ilişkin öğretmen, okul idarecileri ve maarif müfettişlerinin görüşleri nelerdir?

3.Ders denetimlerinin müfettişler tarafından yapılmasının olumlu ve olumsuz yönlerine ilişkin öğretmen, okul idarecileri ve maarif müfettişlerinin görüşleri nelerdir?

4.Ders denetimlerinin kim ya da kimler tarafından yapılması gerektiğine ilişkin öğretmen, okul idarecileri ve maarif müfettişlerinin görüşleri nelerdir?

\section{Yöntem}

Araştırmanın bu bölümünde araştırmanın modeli, örneklem, veri toplama aracı, verilerin toplanması, veri analizi, güvenirlik ve geçerlik çalışmalarına yer verilmiştir.

\section{Araştırmanın modeli}

Çalışma, nitel araştırma yöntemlerinden olgubilim deseninde gerçekleştirilmiştir. Olgubilim deseni, farkında olduğumuz ancak derinlemesine ve ayrıntılı bir anlayışa sahip olmadığımız olgulara odaklanmaktadır. Olgubilim deseni bize tümüyle yabancı olmayan aynı zamanda da tam anlamıyla kavrayamadı̆̆ımız olguları araştırmayı amaçlayan çalışmalar için uygun bir araştırma zemini oluşturur (Yıldırım ve Şimşek, 2011).

\section{Örneklem}

Kahramanmaraş il Millî Eğitim Müdürlüğü bünyesindeki farklı okullarda görevli 10 öğretmen ve 10 okul idarecisi ile Kahramanmaraş il Millî Eğitim Müdürlüğü'nde görevli10 maarif müfettişi bu araştırmanın örneklemini oluşturmaktadır. Araştırma örneklemine ait bazı demografik özellikler Tablo 1 'de verilmiştir. 
Tablo 1.

Araştırma Örneklemine Ait Demografik Özellikler.

\begin{tabular}{|c|c|c|c|c|}
\hline & & & & Frekans \\
\hline & & $\frac{\overleftarrow{a}}{4}$ & $\begin{array}{l}\text { Kadın } \\
\text { Erkek }\end{array}$ & $\begin{array}{l}6 \\
4\end{array}$ \\
\hline & & $e^{2}$ & $\begin{array}{l}\text { 25-30 Arası } \\
\text { 31-35 Arası } \\
\text { 36-40 Arası } \\
\text { 41-45 Arası } \\
\text { 45-50 Arası }\end{array}$ & $\begin{array}{l}1 \\
3 \\
2 \\
3 \\
1\end{array}$ \\
\hline & 完 & $\frac{\varepsilon}{\frac{\delta}{0}}$ & $\begin{array}{l}\text { 1-5 Yıl Arası } \\
6-10 \text { Yıl Arası } \\
11-15 \text { Yıl Arası } \\
16-20 \text { Yıl Arası } \\
21-26 \text { Yıl Arası }\end{array}$ & $\begin{array}{l}1 \\
1 \\
3 \\
2 \\
3\end{array}$ \\
\hline & & 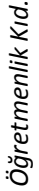 & $\begin{array}{l}\text { 1-5 Yıl Arası } \\
6-10 \text { Yıl Arası } \\
11-15 \text { Yıl Arası } \\
16-20 \text { Yıl Arası } \\
21-26 \text { Yıl Arası }\end{array}$ & $\begin{array}{l}1 \\
1 \\
4 \\
1 \\
3\end{array}$ \\
\hline & & & & Frekans \\
\hline & & $\stackrel{0}{\frac{\pi}{n}}$ & $\begin{array}{l}\text { Kadın } \\
\text { Erkek }\end{array}$ & $\begin{array}{l}2 \\
8\end{array}$ \\
\hline$\frac{\frac{\bar{d}}{\bar{y}}}{\overline{\overline{0}}}$ & & $e^{m}$ & $\begin{array}{l}\text { 25-30 Arası } \\
\text { 31-35 Arası } \\
\text { 36-40 Arası } \\
\text { 41-45 Arası } \\
\text { 45-50 Arası } \\
60 \text { Yaş }\end{array}$ & $\begin{array}{l}2 \\
2 \\
1 \\
1 \\
3 \\
1\end{array}$ \\
\hline 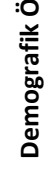 & $\begin{array}{l}\frac{\bar{d}}{0} \\
\frac{\pi}{0} \\
\overline{\frac{\pi}{3}} \\
\text { 히 }\end{array}$ & $\frac{E}{\frac{\delta}{0}}$ & $\begin{array}{l}\text { 5-10 Yıl Arası } \\
11-15 \text { Yıl Arası } \\
16-20 \text { Yıl Arası } \\
21-25 \text { Yıl Arası } \\
35 \text { Yıl }\end{array}$ & $\begin{array}{l}3 \\
1 \\
3 \\
2 \\
1\end{array}$ \\
\hline & & 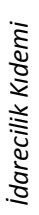 & $\begin{array}{l}\text { 1-5 Yıl Arası } \\
6-10 \text { Yıl Arası } \\
11-15 \text { Yıl Arası } \\
16-20 \text { YIl Arası } \\
21-26 \text { Yll Arası }\end{array}$ & $\begin{array}{l}1 \\
1 \\
4 \\
1 \\
3\end{array}$ \\
\hline & & & & Frekans \\
\hline & & $\frac{\pi}{2}$ & $\begin{array}{l}\text { Kadın } \\
\text { Erkek }\end{array}$ & $\begin{array}{r}0 \\
10\end{array}$ \\
\hline & \pm & $\bar{v}$ & $\begin{array}{l}\text { 40-45 Arası } \\
\text { 46-50 Arası } \\
\text { 55-60 Arası }\end{array}$ & $\begin{array}{l}7 \\
1 \\
2\end{array}$ \\
\hline & $\stackrel{5}{2}$ & $\frac{\frac{\varepsilon}{d}}{\frac{d}{2}}$ & $\begin{array}{l}15-20 \text { Yıl Arası } \\
21-25 \text { Yıl Arası } \\
26-30 \text { Yıl Arası } \\
40 \text { Yıl }\end{array}$ & $\begin{array}{l}3 \\
4 \\
2 \\
1\end{array}$ \\
\hline & & $\frac{\substack{\frac{0}{2} \\
\frac{2}{2}}}{3}$ & $\begin{array}{l}\text { 5-10 Yıl Arası } \\
15-20 \text { Yıl Arası } \\
32 \text { Yıl }\end{array}$ & $\begin{array}{l}7 \\
2 \\
1\end{array}$ \\
\hline
\end{tabular}




\section{Veri Toplama Aracı}

Araştırmanın verileri görüşme yolu ile elde edilmiştir. Görüşme esnasında yarı yapılandırılmış görüşme formu kullanılmıştır. Yarı yapılandırılmış görüşme formunda öğretmenler, okul idarecileri ve maarif müfettişlerine açık uçlu 8 soru yöneltilmiştir. Araştırmacı tarafından oluşturulan görüşme formundaki sorular araştırmanın amaçları göz önünde bulundurularak ve alanyazın taramasından faydalanılarak oluşturulmuştur. Görüşme formlarında yer alan soruların kapsam geçerliğini taşıyıp taşımadığını ortaya çıkarmak için alan uzmanı iki akademisyenle birlikte değerlendirme yapılmıştır. Görüşme formlarının asıl uygulanmasına geçmeden önce bir öğretmen, bir okul idarecisi ve bir maarif müfettişi ile pilot uygulama yapılmıştır. Pilot uygulamada soruların; araştırmanın amacına uygunluğu, anlaşılır ve sıralanışının uygun olup olmadığı değerlendirilmiş, değerlendirme sonucunda şekil, amaç ve kapsam yönlerinden bir sorunun görülmediği ve görüşme formunun bu haliyle asıl uygulamada kullanılabileceği kanaatine ulaşılmıştır. Yapılan pilot uygulama sonucunda katılımcılara yöneltilen sorularda herhangi bir değişikliğe gidilmediğinden pilot uygulamaya katılan 1 öğretmen, 1 okul idarecisi ve 1 maarif müfettişi ile yapılan görüşmelerden elde edilen veriler bu araştırma kapsamında diğer verilerle birlikte değerlendirilmiştir. Araştırma örneklemi içerisinde yer alan öğretmenlere Ö1'den başlayarak Ö10'a kadar, okul idarecilerine Oi1'den başlayarak Oi10'a kadar ve maarif müfettişlerine M1'den başlayarak M10'a kadar isimler verilmiştir. Ders denetimlerinin gerekliliğine ve uzmanlık gerektirip gerektirmediğine, ders denetimlerinin okul müdürleri ya da maarif müfettişleri tarafından yapılmasının olumlu ve olumsuz yönlerine ve ders denetimlerinin kim ya da kimler tarafından yapılması gerektiğine ilişkin açık uçlu sorularla öğretmen, okul idarecileri ve maarif müfettişlerinin bu konulardaki görüşleri ortaya çıkarılmaya çalışılmıştır.

\section{Verilerin Toplanması}

Araştırma örneklemindeki katılımcılarla yapılan görüşmeler 14/11/2016 tarihi ile 12/12/2016 tarihi arasında farklı gün ve saatlerde gerçekleştirilmiştir. Görüşme öncesinde katılımcılara çalışmanın amacı ve yapılan görüşmenin gizliliği hakkında bilgiler verilmiş, katılım için gönüllü olup olmadıkları sorulmuştur. Öğretmen ve idarecilerle yapılan görüşmeler görevli oldukları kurumlarda, maarif müfettişleri ile yapılan görüşmeler ise Kahramanmaraş il Millî Eğitim Müdürlüğü Maarif Müfettişleri Başkanlığı'nda gerçekleştirilmiştir. Görüşmeler katılımcılarla karşılıklı konuşma şeklinde gerçekleştirilmiş ve katılımcıların yanıtları araştırmacı tarafından formlara yazılarak kaydedilmiştir. Araştırma örneklemindeki her bir kişi ile yapılan görüşme ortalama 30 dakika sürmüş toplam 30 kişi ile toplamda yaklaşık 900 dakika (15 saat) süren görüşmeler yapılmıştır. Görüşme esnasında katılımcılara yöneltilen sorular önceden belirlenmiş olmakla beraber, gerektiği durumlarda soru içerikleri değiştirilmeden farklı şekilde sorma yoluna ve yer yer tekrar sorma yoluna da gidilmiştir.

\section{Veri Analizi}

Katılımcılarla yapılan görüşmeler sonucunda elde edilen verilerin önce kavramsallaştırılması daha sonra da ortaya çıkan kavramlara göre mantıklı bir biçimde düzenlenmesi ve buna göre veriyi açıklayan temaların saptanmasını gerektiren içerik analizi yöntemi kullanılmıştır (Yıldırım ve Şimşek, 2011). Veriler araştırmacı tarafından okunarak kodlamalar yapılmış, araştırmacı tarafından ikinci kez okuma yapılmış ve ikinci okuma sonunda bazı veri kısımlarını kodlamak için kullanılan kavramlar değiştirilmiştir. Oluşan kodların hangi temalar altında toplanabileceği üzerinde çalışılmış ve oluşabilecek temalar belirlenmiştir. Araştırmacı tarafından yapılan kodlamalar ve tema oluşturma çalışmasından sonra alan uzmanı ve içerik analizi yöntemi konusunda yeterliliği bulunan bir akademisyen tarafından bütün veriler üzerinde kodlama ve kodlardan tema oluşturulması işlemleri gerçekleştirilmiştir. Araştırmacı tarafından oluşturulan kodlar ve temalar ile uzman kişi tarafından oluşturulan kodlar ve temalar karşılaştırılmış bu karşılaştırma neticesinde kodların ve temaların ne olacağına ilişkin nihai karar verildikten sonra kodlamalara ilişkin frekans tabloları oluşturulmuştur. Bu aşamadan sonra bulguların betimlemeye hazır hale geldiği kanaati oluşmuştur. 


\section{Güvenirlik ve Geçerlik}

Araştırma sürecinde araştırmacının araştırmanın yöntem ve aşamalarını açık ve anlaşılır bir biçimde tanımlaması, veri toplama, analiz etme, yorumlama ve sonuçlara ulaşma konularında neler yapıldığının araştırmada ifade edilmesi, araştırmanın ham verilerinin başkaları tarafından incelenebilecek biçimde saklanması bu araştırmanın dış güvenirliğini sağlayan hususlar olarak değerlendirilmektedir. Araştırma sorularının açık bir biçimde ifade edilmesi, araştırma verilerinin soruların gerektirdiği biçimde ayrıntılı ve amaca uygun bir biçimde toplanmaya çalışılması, verilerin alan uzmanı bir diğer akademisyen tarafından kodlanması ve oluşan iki ayrı kodlamanın karşılaştırılması araştırmanın iç güvenirliğini sağlayan nitelikler olarak görülmektedir (Yıldırım \& Şimşek, 2011).Araştırmacı tarafından yapılan kodlamalar ile alan uzmanı bir diğer akademisyen tarafından yapılan kodlamalar birbirleri ile karşılaştırılmış ve tutarlılıkları incelenmiştir. Elde edilen kodların benzer ve uyumlu olduğu görülmüştür. Araştırmacıların yaptığı kodlamalardan elde edilen toplam kod sayıları belirlenmiştir. Araştırmacıların yaptıkları kodlamalar arasındaki uyumun yüzdeliğini belirlemek için aşağıdaki formül kullanılmıştır (Emmer\&Millett, 1970; Akt. Selçuk, 2000):

Yüzdelik Uyum $=100\left(1-\frac{A-B}{A+B}\right)$

Araştırmacı tarafından yapılan veri analizi sonucu elde edilen kod sayısının 114, kodlama yapan diğer akademisyen tarafından yapılan veri analizi sonucunda elde edilen kod sayısının 70 olduğu görülmüştür. Bu durumda;

Yüzdelik Uyum $=100\left(1-\frac{114-70}{114+70}\right)$

Yüzdelik Uyum =\% 76

Kodlamalar arasındaki uyumun \%75 ve üzeri olması gerektiği (Emme r\& Millett, 1970; Akt. Selçuk, 2000) göz önünde bulundurulduğunda iki ayrı kodlama arasındaki uyum düzeyinin \%76 olması kodlamalar arasında bir tutarlılığın ve uyumun olduğunu, dolayısıyla verilerin güvenilir olduğunu göstermektedir.

Araştırmada katılımcı görüşlerine doğrudan alıntılarla yer verilmesi, araştırma bulgularının kendi içinde tutarlılık göstermesi, araştırma örneklemine ait özelliklerin tanımlanmış olması ise araştırmanın geçerliğini arttıran özellikler olarak değerlendirilmiştir.

\section{Bulgular}

\section{Ders Denetimlerinin Gerekliliği}

Ders denetimlerinin gerekliliğine ilişkin öğretmen, okul idarecileri ve müfettişlerin görüşlerinin analizi sonucu elde edilen temalar ve temalara ilişkin kodlara Tablo 2'de verilmiştir. 
Tablo 2.

Ders Denetimlerinin Gerekliliğine Iliş̧kin Öğretmen, Okul Idarecisi ve Müfettiş Görüşleri.

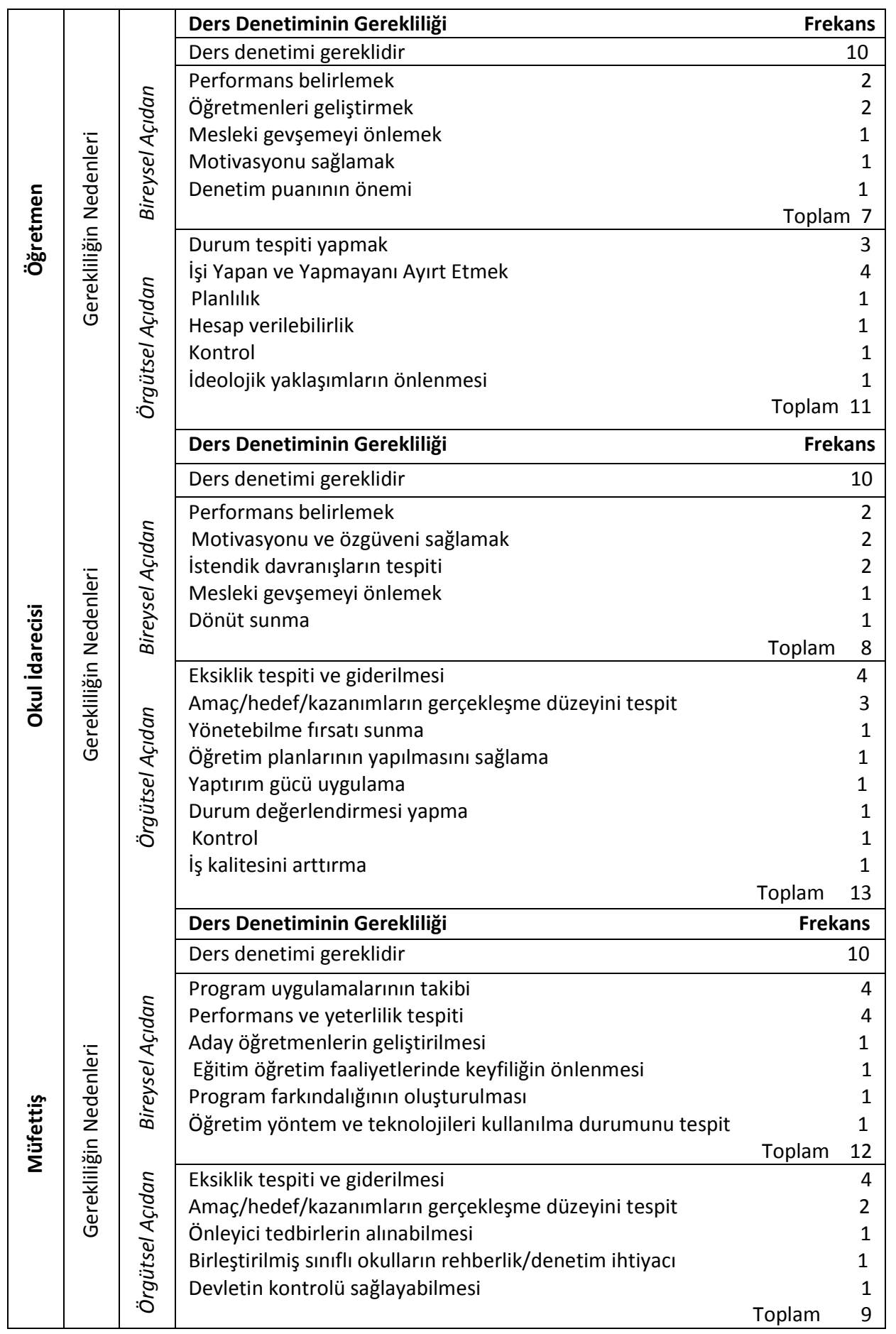

Tablo 2'de görüldüğü gibi ders denetiminin gerekliliğine ilişkin olarak görüşmelerden elde edilen verilerin içerik analizi sonucunda bütün öğretmenlerin, okul idarecilerinin ve müfettişlerin ders denetimlerinin yapılması gerektiği yönünde görüş bildirdikleri görülmektedir. Katılımcılar ile yapılan 
görüşmelerden elde edilen veriler ışığında denetimin gerekliliği; bireysel açıdan ve örgütsel açıdan gereklilik şeklinde iki tema altında toplanmıştır.

Öğretmenler, bireysel açıdan denetimin gerekliliği temasında; "öğretmenlerin performanslarının belirlenmesi, geliştirilmesi, motivasyonlarının sağlanması ve mesleki gevşemelerinin önüne geçilmesi, denetim sonucu alınacak puandan dolayı öğretmenin çalışma arkadaşlarına mahcup olmaması için daha çok çalışma isteği duyacağı" sebeplerinden dolayı denetimin gerekli olduğunu ifade etmektedirler. Öğretmenler, bu temada en çok öğretmen performansının belirlenmesi ve öğretmenlerin geliştirilmesi bakımından denetimi gerekli görmektedirler.

Öğretmen görüşlerine göre; "örgüt ortamında işini yapan ve yapmayan bireyleri tespit edebilmek, eğitim öğretim faaliyetlerinin yapılıp yapılmadığına dair durum tespiti yapabilmek, eğitim öğretim işlerinin planlı yürütülebilmesi, kontrolü sağlama, hesap verilebilirlik, ideolojik fikirlerin eğitime yansıtılmaması" için denetimin örgütsel açıdan gerekli olduğu görülmektedir. Öğretmenler en fazla, işini yapan ve yapmayan çalışanları ayırt edebilmek ve eğitim öğretim faaliyetlerinin yürütülmesine ilişkin durum tespiti yapabilmek için denetimin örgütsel bir zorunluluk olduğunu ifade etmektedirler. Bu durumda öğretmenlerin çalışanla çalışmayan arasındaki farkın ortaya konulması gerektiğine yönelik güçlü inançlarının var olduğu, bu ayııımın da ancak denetimle ortaya konulabileceğini düşündükleri ifade edilebilir. Bütün sistemlerde denetimin rolü sistemin işleyişine ait bir fotoğraf ortaya koymaktır. Öğretmenler de denetimden eğitim öğretim faaliyetlerine ilişkin bütün durumların tespitini yapmasını, işleyişi her yönüyle ortaya koymasını beklemektedirler.

Öğretmenlerin görüşme sırasında denetimin yapılmasının birey ve örgüt açısından zorunlu olduğuna ilişkin açıklamalarına örnek olabilecek bazı alıntılar aşağıda verilmiştir:

“... Yani motivasyonumuz ve kendi çalısmalarımızın değerlendirilmesi, eksik ve olumlu yönleri görmek adına yapılmalıdır. Yeter ki objektif olsun"(Ö3)

"... Çünkü denetim yapılmadığında öğretmenler gelişsim ve değişime karşı kendilerini kapatıyorlar. Eğitsel amaçlara ulaşma derecesini ölçmek için denetim şarttır." (Ö6)

"... Şimdi çok rahat öğretmenler var ve öğretmenler çok farklı bilinç düzeyine sahip. Bunun için denetim yapılmalı. Çok yaşlı öğretmenler var ve bunlar unumu eledim eleğimi astım formatındalar. Çalışanla çalışmayanın ayrımının yapılabilmesi için denetim yapılmalıdır. Kontrol altında olan insan bir şeyleri daha iyi yapar. Kontrol şarttır. Denetim sonucu yapılan değerlendirmede öğretmenler zümre ve meslektaşlarından daha düşük bir değerlendirme sonucu ile karşılaşmamaları adına daha iyi çalışacaktır. Hani öğretmenler arasında sen kaç aldın, ben kaç aldım, değerlendirme objektif mi ya da yüksek aldı hak etti mi ya da düşük aldı o bunu hak etmiyordu falan gibi değerlendirmeler yapılmaktadır. Bu da denetimin önemini, gereğini ortaya koymaktadır."(Ö7)

"...ideolojik fikirlerin, görüşlerin eğitime yansıtılmaması adına denetim yapılmalıdır. Kendi çocuğumuza verdiğimiz 1 TL'nin hesabını çocuğumuza soruyoruz. Devlet de eğitimin nerede olduğunu elbette denetleyecek. Hesap verilirliği sağlamak adına denetim yapılmalıdır."(Ö8)

Okul idarecileri, bireysel açıdan denetimin gerekliliği temasında; "öğretmenlerin performanslarının belirlenmesi, motivasyon ve özgüvenlerinin arttırıması, olumlu mesleki davranışlarının ortaya çıkarılması ve ögretmenlerin mesleki manada gevşemelerinin önüne geçilmesi" açılarından dolayı denetimi gerekli görmektedirler.

Okul idarecileri, örgütsel açıdan denetimin gerekliliği temasında; "kurumları yönetebilmek, eğitim öğretim faaliyetlerindeki eksiklikleri ve yanlışıkları tespit ederek giderilmesini sağlamak, öğretim planlamalarının yapılma durumunu incelemek, durum değerlendirmesi yapmak, iş kalitesini arttırmak, eğitim öğretim faaliyetlerinin yapııı yapılmadığını, amaç/hedef ve kazanımlarının gerçekleşme durumlarııı ve düzeylerini tespit etmek, öğretmenlerin yaptıkları çalışmalar hakkında dönüt alabilmelerini sağlamak, kontrolü sağlamak ve yaptırım gücü uygulamak" için denetimin gerekli olduğu ifade edilmektedir. 
Okul idarecileri ders denetimlerini daha çok örgütsel açıdan bir gereklilik olarak görmektedirler. Bu gerekliliğin, denetimin yönetimin bir parçası olma rolünden kaynaklandığı ifade edilebilir. Denetim; durum tespiti, değerlendirme, düzeltme ve geliştirmeyi içeren bir süreçtir. Okul idarecilerince ifade edilen gereklilik durumları denetimden beklenen bu işlevleri ifade etmektedir.

Okul idarecilerinin açıklamalarına örnek olabilecek bazı alıntılar aşağıda sunulmuştur:

"Bence ders denetimleri yapılmalıdır. Çünkü yönetimde bir söz vardır. Denetim yapmıyorsan sen yönetmiyorsundur diye." (Oi1)

"...Programda belirtilen hedeflere öğretmenlerin ne derece ulaştığını ortaya çıkarmak için sürekli ve periyodik olarak denetim yapılmalıdır." (Oi2)

"... Bir kurumun iş kalitesi iyi bir denetime bağlıdır." (Oi3)

"... Çünkü biz ne kadar da olsa kontrol edilmeden bir şeyler yapamıyoruz. Öğretmenler ders denetimleri yapılmadığında çok rahat davranıyorlar."(Oi4)

“...Kişinin dışarıdan değerlendirilmesi fark edilmeyen yanlışların ve eksikliklerin ortaya konması adına, ögrretmenlerin olumlu yönlerinin ortaya çıkarılarak motivasyonlarının ve öz güvenlerinin artması adına gerekli olduğunu düşünüyorum." (Oi5)

"...Çünkü öğretmenleri motive etmek için bu gereklidir." (Oi7)

Maarif müfettişlerinin, ders denetimlerinin bireysel açıdan gerekliliğine ilişkin görüşleri analiz edildiğinde; "programların uygulanma düzeyinin tespiti, öğretmen performans ve yeterliliklerinin tespiti, aday öğretmenlerin geliştirilmesi, eğitim öğretim sürecinde keyfiliğin önlenmesi, öğretmenlerin öğretim programlarına ilişkin farkındalıklarının arttırılması, öğretim faaliyetlerinde öğretim ilke ve yöntemlerin kullanılma durumlarının tespiti" nedenlerinden dolayı denetimin bireysel manada gerekli olduğu görülmektedir.

Örgütsel açıdan denetimin gerekliliğine ilişkin maarif müfettişleri; "eğitim süreci içerisinde yapılan eksiklik ve yanlışlıkların belirlenerek ortadan kaldırılması, eğitsel ve öğretimsel amaçlara/hedeflere/kazanımlara ulaşılma durumlarının ve düzeylerinin tespiti, önleyici tedbirlerin alınabilmesi, birleştirilmiş sınıfı okulların rehberlik ihtiyacının karşılanması, devletin kontrolünün sağlanması" gereklilikleri denetimi örgütsel açıdan zorunlu kılan nedenler olarak açıklamışlardır.

Maarif müfettişlerinin açıklamalarına örnek olabilecek bazı alıntılar aşağıda sunulmuştur:

“...Eğitsel faaliyetlerin doğruluğuna, eksikliğine ilişkin bulgular ancak denetimle gerçekleşir. Uygun yöntem, teknik uygulama durumunu ancak denetimle görürüz. Buna ilişkin eğitsel manada tedbirlerin alınması, önleyici çalışmaların yapılması, müdahalenin zararları önlemesi diyebiliriz." (M1)

"...En azından aday öğretmenlerde ve birleştirilmiş sınıflarda yapılmalıdır." (M4)

“...Çünkü öncelikle program odaklı eğitim öğretim konusunda sapmaların tespiti, bununla ilgili programın merkeze alınmasına ilişkin olarak tespitin yapılması gerekmektedir. Programla ilgili öğretmen farkındalığı oluşturmak için gereklidir." (M7)

"...Çünkü derslerin amaçları gerçekleştiğinde okulun dolayısıla Millî Eğitimin genel amaçlarına ulaşılacaktır. Bu itibarla anılan çalışmaların ne denli yapılıp yapılmadığının profesyonelce gözlenip sapmalar varsa düzeltme işleminin gerçekleşmesi için ders denetimlerinin yapılması çok elzemdir." (M9)

Maarif müfettişlerinin tamamı ders denetimlerinin yapılması gerektiğini vurgulamaktadırlar. Maarif müfettişleri daha çok öğretim programlarının uygulanma durumlarının tespiti, öğretmen performans ve yeterliliğinin ortaya çıkarılması, eğitim öğretim faaliyetleri ile ilgili eksik ve yanlışlıkların giderilmesi bakımından denetimin yapılması gerektiğini belirtmişlerdir. Denetimin; durum tespiti, değerlendirme, düzeltme ve geliştirme rolleri açısından bakıldığında bu rollerin gerçekleştirilmesi için denetimin gerekli olan bir süreç olduğu ifade edilebilir. Bunun yanında denetimin eğitimde keyfiliğin önlenmesi açısından gerekli olduğu, eğitsel amaç/hedef/kazanımlara ulaşma düzeyinin denetimle ortaya konulabileceği, sınıf içerisinde yapılan uygulamaların yerindeliğinin denetimle tespit edilebileceği ve devletin eğitim faaliyetlerini kontrol altında tutmasında denetimin önemli bir rolü olduğu ortaya çıkmaktadır. 


\section{Uzmanlık Gerektiren Bir Alan Olarak Ders Denetimi}

Ders denetimlerinin uzmanlık gerektiren bir alan olup olmadığına ve uzmanlık alanıysa bunun sebeplerinin neler olduğuna ilişkin öğretmen, okul idarecileri ve müfettişlerin görüşlerinin analizi sonucu elde edilen temalar ve temalara ilişkin kodlar Tablo 3'te verilmiştir.

Tablo 3.

"Bir Uzmanlık Alanı Olarak Ders Denetimi”ne Ilişkin Görüşler.

\begin{tabular}{|c|c|c|c|c|}
\hline \multirow{7}{*}{ 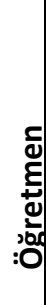 } & \multirow{7}{*}{$\begin{array}{l}\frac{\bar{d}}{\frac{1}{c}} \\
\frac{d}{0} \\
\frac{d}{Z}\end{array}$} & Ders Denetimi Uzmanlık Gerektiren Bir Alan mıdır? & Frek & \\
\hline & & Ders denetimi uzmanlık gerektiren bir alandır. & & 10 \\
\hline & & Alan hâkimiyeti & & 8 \\
\hline & & Denetim formasyonuna sahip olma & & 6 \\
\hline & & İnsan ilişkilerinde ve iletişimde yeterlilik & & 4 \\
\hline & & Öğretmenlik ve müfettişlik tecrübesi & & 2 \\
\hline & & Yaş gruplarının özelliklerini bilme & & 2 \\
\hline \multirow{12}{*}{$\begin{array}{l}\overline{\bar{y}} \\
\bar{y} \\
. \overline{\frac{v}{0}} \\
\overline{\bar{y}} \\
\overline{0}\end{array}$} & \multirow{13}{*}{ 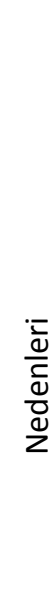 } & & Toplam & 22 \\
\hline & & Ders Denetimi Uzmanlık Gerektiren Bir Alan mıdır? & Fre & ans \\
\hline & & Ders denetimi uzmanlık gerektiren bir alandır. & & 10 \\
\hline & & Alan hâkimiyeti & & 5 \\
\hline & & İnsan ilişkilerinde ve iletişimde yeterlilik & & 4 \\
\hline & & Mesleki tecrübe & & 3 \\
\hline & & Denetim formasyonuna sahip olma & & 2 \\
\hline & & Mevzuata hâkim olma & & 2 \\
\hline & & Yenilikçi ve vizyon sahibi olma & & 2 \\
\hline & & Kriz yönetebilme, pratik çözümler üretebilme & & 1 \\
\hline & & Zaman yönetimi & & 1 \\
\hline & & Öğrencilerin gelişim ve davranış özelliklerini bilme & & 1 \\
\hline \multirow{8}{*}{ 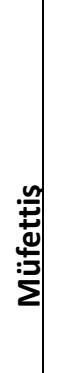 } & & & Toplam & 21 \\
\hline & \multirow{7}{*}{$\begin{array}{l}\frac{\bar{d}}{d} \\
\frac{d}{d} \\
\frac{d}{d} \\
z\end{array}$} & Ders Denetimi Uzmanlık Gerektiren Bir Alan mıdır? & Fre & ans \\
\hline & & Ders denetimi uzmanlık gerektiren bir alandır. & & 10 \\
\hline & & Öğretmenlik meslek bilgisine sahip olma & & 7 \\
\hline & & Denetim formasyonuna sahip olma & & 5 \\
\hline & & Alan hâkimiyeti & & 4 \\
\hline & & Mesleki tecrübe & & 2 \\
\hline & & & Toplam & 18 \\
\hline
\end{tabular}

Tablo 3'te görüldüğü üzere ders denetiminin uzmanlık gerektiren bir alan olup olmadığına ilişkin olarak bütün öğretmenler, okul idarecileri ve müfettişler ders denetiminin uzmanlık gerektiren bir alan olduğunu ifade etmişlerdir.

Öğretmenler, ders denetiminin neden uzmanlık gerektirdiğine ilişkin olarak; "ders denetimi yapabilmek için alana hâkim olmak, denetim formasyonuna sahip olmak, insan ilişkileri ve iletişim konularında yeterli olmak, öğretmenlik ve müfettişlik tecrübesine sahip olmak, öğrenci yaş guruplarının özelliklerini bilmek" konularında yeterliliğe sahip olunması gerektiğini belirtmektedirler. Alana hâkimiyet, öğretmenlere göre ders denetimi yapabilmek için en fazla sahip olunması gereken uzmanlık olarak görülmektedir. Müfettişlerin, öğretim programlarını bilmeleri, programda yer alan kazanımların farkında olmaları, kazanımların nasıl kazandırılacağına ilişkin bilgi yeterlilikleri, öğretim planları konusundaki teknik yeterlilikleri alan hâkimiyeti olarak değerlendirildiğinde bunun uzmanlığın büyük bir kısmını oluşturduğu ifade edilebilir. 
Denetim, öğretmenlerce, kendi içerisinde ilke ve kuralları olan alan yani bir disiplin olarak görülmektedir. Bu bakımdan ders denetimi belli ilke ve kurallara göre ve belli bir süreç dâhilinde işleyecek bir uzmanlık alanı olarak görülmektedir. Öğretmenler ders denetimi yapacak uzman kişinin insan ilişkileri ve iletişim alanında da gerekli yeterliliğe sahip olmaları gerektiğini belirtmekte ve bunu önemsemektedirler.

Öğretmenlerin açıklamalarına örnek olabilecek bazı alıntılara aşağıda yer verilmiştir:

“...Denetleyeceği alanla ilgili bilgiye sahip olması gereklidir. Iletişimi, insan ilişkileri alanında yeterli olması gerekir denetim elemanının." (Ö1)

“...Denetimi yapan kişi her türlü ayrıntıyı bilmeli, denetleyeceği alana hâkim olmalı, böylece gerçek bir değerlendirme yapılsın."(Ö3)

"...Ben ana sınıfı öğretmeniyim. Beni denetleyecek kişi alanımda uzman olmalıdır. Neyi, nasıl denetleyeceğini bilmelidir. Yoksa öğretmenin yaptığı çalışmalar göz ardı edilebiliyor. O yaş grubu çocukların özelliklerini bilmelidir. Teknik manada denetime ilişkin yeteri bilgiye sahip olmalıdır denetçi."(Ö4)

“...Neyi denetleyeceğini bilmeli, karşısındaki öğretmene nasıl davranacağını bilmesi için uzmanlık gerektirdiğini düşünüyorum. Denetimle ilgili süreçler ve denetimin her yönü ile ilgili bilgi sahibi olunmalıdır." (Ö9)

Okul idarecileri, ders denetiminin neden uzmanlık gerektirdiğine ilişkin olarak; "Ders denetimi yapabilmek için alana hâkim olmak, insan ilişkileri ve iletişim konularında yeterli olmak, öğretmenlik ve müfettişlik tecrübesine ve denetim formasyonuna sahip olmak, mevzuata hâkim olmak, vizyon sahibi ve yenilikçi olmak, kriz yönetimi ve pratik çözümler üretebilme becerisine sahip olmak, zaman yönetimi konusunda yeterli olmak, öğrenci yaş guruplarının özelliklerini bilmek" konularında yeterliliğe sahip olunması gerektiği belirtilmektedir. Okul idarecileri en fazla, alana hâkimiyet ile insan ilişkileri ve iletişim becerilerindeki yeterliliği uzmanlık alanı kapsamında değerlendirmişlerdir. Ders denetimi için gerekli olan yeterlik alanlarına bakıldığında denetim elemanının özellikle program ve iletişim becerileri noktalarında yeterliliğe sahip olmaları gerektiği ifade edilebilir.

Okul idarecilerinin açıklamalarına örnek olabilecek bazı alıntılar aşağıda sunulmuştur:

"...Denetim bilimsel bir olay olduğu için bu alanda eğitim alınması şarttır. Uzmanlık alanında insan ilişkileri, zaman yönetimi, kriz yönetimi... gibi konularda uzmanlık gerektirir." (Oi1)

"...Karşı tarafa yardımın yapılabilmesi için alana hâkim olmak gerekir. ... Denetim teknik bilgi ve beceri içerir. Bu bakımdan herkes denetim yapamaz."(Oi2)

"...Sadece akademik uzmanlık değil, insan ilişkileri, iletişim alanında yeterli, vizyon sahibi, yeniliklere açık ve yenilikleri takip eden ve bunları alanda uygulayabilen uzman kişi olunması gerekir. Ayrıca bu uzmanlar pratik düşünebilen, pratik yöntem ve çözümler geliştirip kullanabilen kişiler olmaları gerekli olduğunu düşünüyorum."(Oi5)

“...Her şey uzmanlık gerektirir. Nasıl denetim yapacağınızı bilmezsiniz yoksa. ... Alanı, öğretmenliği bilmelidir. Öğretim programı gibi alanlarda uzman olmalıdır. Mevzuatın çok iyi bilinmesi gerekiyor." (Oi7)

"...Denetim alanında eğitim almış, denetimin ilkelerini, süreçlerini, amaçlarını iyi bilen kişiler tarafından gerçekleştirilmesi gerekir." (Ois)

“...Ben 35 yıllık idareciyim. Dört yıl öğretmenliğim var. Öğretmene karşı zor durumda kalmamak için öğretim programlarına bakıyorum. Eksik bir yönümün kalmaması gerekiyor..."(Oig)

Müfettişler, ders denetiminin neden uzmanlık gerektirdiğine ilişkin olarak; "ders denetimi yapabilmek için öğretmenlik meslek bilgisine sahip olmak, denetim formasyonuna sahip olmak, alana hâkim olmak, öğretmenlik ve müfettişlik tecrübesine sahip olmak" konularında yeterliliğe sahip olunması gerektiğini belirtilmektedirler. Müfettişler ders denetimini uzmanlık gerektirdiğini, bu uzmanlığın da en fazla öğretmenlik meslek bilgisine sahip olma ile gerçekleştiğini ifade etmektedirler. Öğretmenlik meslek bilgisi; pedagojik formasyon, alan bilgisi ve genel kültür alanlarındaki bilgileri ifade eder. Öğretmenin yeterli olması gereken bu alanlarda ders denetimi yapacak olan denetim elemanlarının da yeterli olmak 
zorunda oldukları ifade edilebilir. Müfettişler, denetimin bir disiplin olduğunu, bu disiplinin ilke ve kurallarına hâkim olmak gerektiğini bu bakımdan ders denetimlerinin uzmanlık gerektiren bir alan olduğunu belirtmektedirler.

Müfettişlerin açıklamalarına örnek olabilecek bazı alıntılar aşağıdaki gibidir:

“...Çünkü her ders birbirinden farklıdır. Fen branşından birine ingilizce branşındaki birinin rehberlik/denetim yapması yanlış olur." (M1)

"...Çünkü öğretmenlik mesleki özelliği olan, kendi içerisinde pedagojik alan ve genel kültür anlamında donatılmış bir meslek olduğundan bunların denetiminin de aynı ölçüde aynı meslek içerisinden gelen kişilerce yapılması, algılama ve empati kurmanın daha kolay olacağını, teftişin ve denetimin bir takım özel mesleki ve teknik bilgi ve beceri gerektirdiğinden uzmanlık gerektiren bir alan olduğunu düşünüyorum."(M2)

"...Eğitime ilişkin belli bir tecrübe, bilgi birikimine sahip olunması gerekir. Denetim disiplinine ilişkin ilke, kural ve süreçler vardır. Bu süreçlerle ilgili yeterliliğe sahip olunması gerekir. Iletişim bunların içerisinde en önemli yeterliliktir."(M4)

“...̈̈̆retmeyi ve öğrenmeyi bilmek, pedagojik formasyon sahibi olmak gerekir."(M5)

"...Öncelikle ders denetimi yapan kişilerin programa hâkim olması, eğitimin felsefesinden haberdar olmaları bakımından gereklidir. Denetimin belli ilke, kural ve süreçlerinden haberdar olunması uzmanlık gerektirmektedir."(M7)

\section{Okul Müdürlerinin Ders Denetimi Konusundaki Uzmanlıkları}

Okul müdürlerinin ders denetimi konusunda uzman olup olmadıklarına ve bunun sebeplerine ilişkin öğretmen, okul idarecileri ve müfettişlerin görüşlerinin içerik analizi sonucu elde edilen temalar ve temalara ilişkin kodlar Tablo 4'te verilmiştir. 
Tablo 4.

Okul Müdürlerinin Ders Denetimi Konusundaki Uzmanlıklarına iliş̧kin Görüşler.

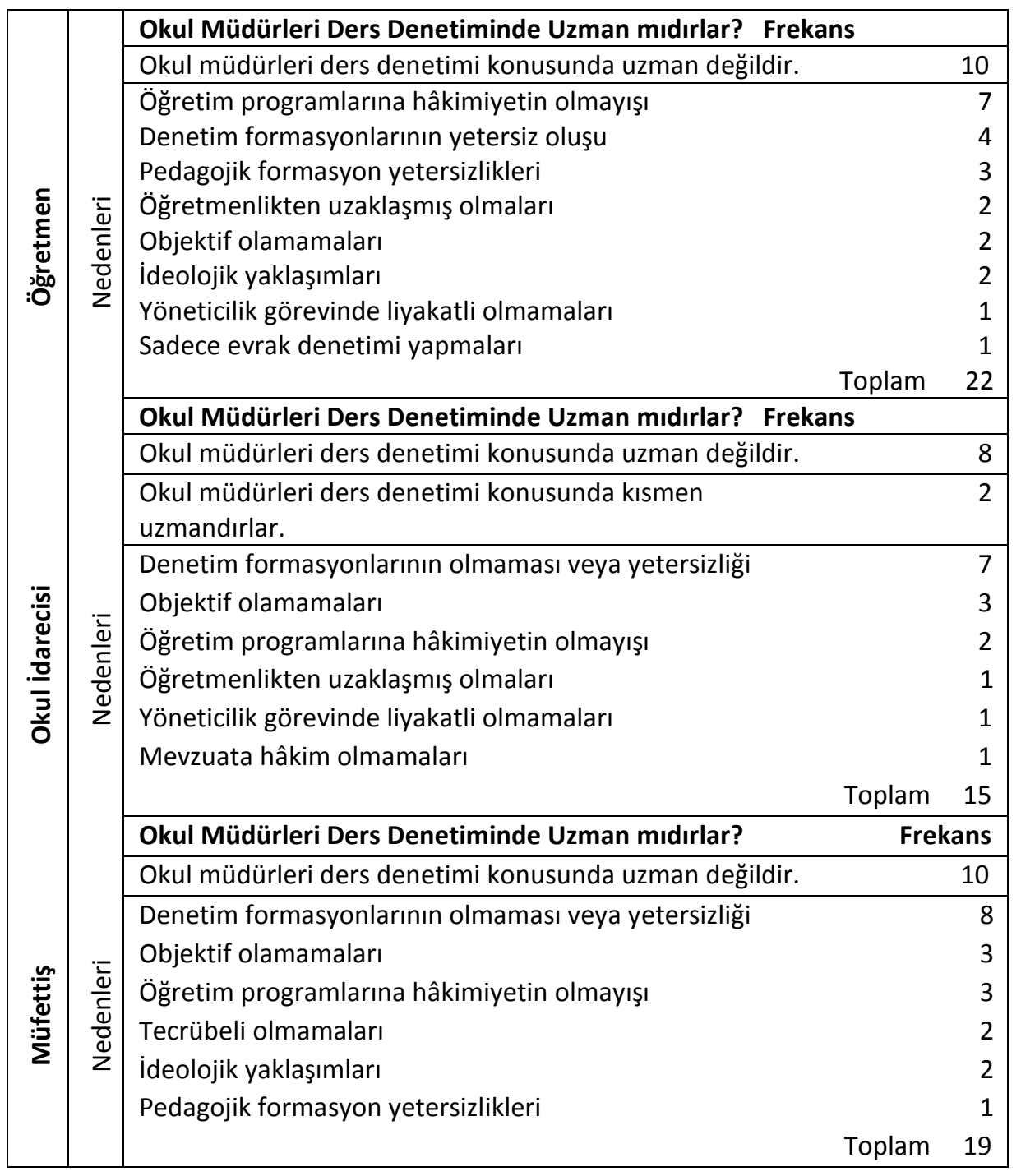

Tablo 4'e bakıldığında kendileri ile görüşme yapılan öğretmenlerin tamamı, okul idarecilerinin büyük bir çoğunluğu (8/10) ve müfettişlerin tamamı; okul müdürlerinin ders denetiminde uzman olmadıklarını, iki okul idarecisi de kısmen uzman olduklarını ifade etmişlerdir. Bu bakımdan denetimin paydaşları olan öğretmenler, okul idarecileri ve müfettişler, okul müdürlerinin ders denetiminde uzman olmadıklarını düşünmektedirler. Hâlihazırdaki uygulamaya göre ders denetimlerini yapan okul müdürlerinin de ders denetimi noktasında kendilerini uzman görmemeleri manidar bir bulgu olarak değerlendirilebilir.

Ders denetimleri konusunda okul müdürlerinin neden uzman olarak görülmediklerine dair görüşlerin içerik analizinden elde edilen bulguları aşağıda yer almaktadır:

Öğretmenler, ders denetimi konusunda okul müdürlerinin uzman olmadıklarını ifade etmektedirler. Bunun gerekçeleri ise; "okul müdürlerinin öğretim programlarına hâkim olamayışları, denetim formasyonuna sahip olamamaları veya bu konudaki yetersizlikleri, pedagojik formasyon yetersizlikleri, uzun süre öğretmenlikten uzak kalmış olmaları, değerlendirmede objektif olamamaları, değerlendirme sürecinde ideolojik davranmaları, yöneticilik görevi için gerekli liyakati taşımamaları, yaptıkları denetimlerin sadece evrak boyutunda kalması"dır. Ders denetimi konusunda okul müdürlerinin uzman 
olmadıkları noktasındaki öğretmen görüşlerinin en fazla, okul müdürlerinin öğretim programlarına hâkim olmamalarından, denetim formasyonuna ve pedagojik formasyona sahip olmamalarından kaynaklandığı görülmektedir.

Öğretmenlerin açıklamalarına örnek olabilecek bazı alıntılar aşağıda sunulmuştur:

"...Okul müdürlerinin siyasi yönlerinin olmaması lazım. İdeolojik yaklaşımdan dolayı uzmanlığın olmadığını düşünüyorum." (Ö1)

"... Yıllarca idarecilik yapmaları dolayı ögretim programlarından uzak olmalarından dolayı uzman olmadıklarını düşünüyorum. Denetimin ilke ve süreçlerine vakıf olunması gerekir ki profesyonel olabilsin."(Ö3)

"... Müdürlerin genelde kıdemli, mesleğinin son dönemlerini yaşayan, gelişim ve değişime açık olmadıkları ve denetim alanında uzman olmadıkları için bu alanda yetkin ve uzman olmadıklarını düşünüyorum."(Ö6)

"... Birileri idareye daha yakın, birileri de daha uzak bazıları ise nötrdür. Bu durum değerlendirmeye bir şekilde yansıyacak, değerlendirmede birtakım sapmalar olacaktır. Idareciler öğretmenlikten daha uzak oldukları için denetimde de eksiklik olacaktır."(Ö7).

“... Idarecilerin liyakatli kişilerden oluştuğunu düşünmüyorum. Okul müdürlerinin performans değerlendirmesinde objektiflik sergilediklerini düşünmüyorum. Müdürler ideolojik ya da kişisel ilişkilerden dolayı tarafgir davranabilmektedirler."(Ög)

"... Alan bilgisine sahip olmamak müdürler için bir yetersizliktir. Denetimde sadece sınıf düzenine ve evraka bakıyorlar. Özde denetim (kazanım denetimi gibi) olmuyor."(Ö10)

Okul idarecileri, ders denetimi konusunda okul müdürlerinin uzman olmadıklarını ifade etmektedirler. Bunu, şu gerekçelere dayandırmaktadırlar: "Okul müdürlerinin denetim formasyonuna sahip olmamaları veya bu konudaki yetersizlikleri, değerlendirmede objektif olamamaları, öğretim programlarına hâkim olamayışları, uzun süre öğretmenlikten uzak kalmış olmaları, yöneticilik görevi için gerekli liyakati taşımamaları, mevzuata hâkim olmamaları". Ders denetimi konusunda okul müdürlerinin uzman olmadıkları noktasında okul idarecileri en fazla, okul müdürlerinin denetim formasyonuna sahip olmamaları veya bu konudaki yetersizliklerinden, değerlendirmede objektif olamamalarından ve öğretim programlarına hâkim olamamalarından bahsetmektedirler. Okul müdürlerinden sadece Oї ve Oï ders denetimi konusunda okul müdürlerinin kısmen uzman olduklarını belirtmişlerdir.

Okul idarecilerinin bu konu ile ilgili açıklamalarına örnek olabilecek bazı alıntılar aşağıda sunulmuştur:

“...Denetim bilimsel bir süreçtir. Bu sürecin eğitimini almadığı için uzman değildir. Denetim yeterlikleri istenilen düzeyde değildir. ... Öğretmeni yakinen tanıdığı için duygusal kararlar verme riskleri çoktur."(Oi1)

“...Hem program yeterlikleri hem de denetim yeterlikleri konusunda yeterli değillerdir. Bu disiplinin ilke ve kurallarına hâkim olmak ve uygulayabilmek için bu alanda ihtisaslaşmak gerekir. Müdürlerde böyle bir ihtisaslaşmanın olmadığını düşünüyorum."(Oi2)

“...Kurumuna hâkim, personeline hâkim bir okul idarecisi denetimde yeterli olabilir. Öğretim programı konusunda yetersizlik görülebilir ama."(Ö3)

"...idarecilerin çoğu uzun yıllar idarecilik yaptıklarından uygulamadan uzaktırlar. Bu durumda onların objektif olamayacağını düşünüyorum. ...Okul idarecilerinin seçimi noktasında liyakat olmadığından denetimde de yeterliliğin olmadığını düşünüyorum."(Oi5)

"...Okul müdürlerinin denetim hususundaki yetersizliklerinin sebeplerinin kendilerinin denetim konusunda yetişmemeleri, denetime ilişkin ilke ve süreçleri bilmemeleri diyebiliriz."(Oï)

Müfettişler, ders denetimi konusunda okul müdürlerinin uzman olmadıklarını ifade etmektedirler. Bunun nedenlerini ise şu şekilde açıklamaktadırlar: "Okul müdürlerinin denetim formasyonuna sahip olmamaları veya bu konudaki yetersizlikleri, değerlendirmede objektif olamamaları, öğretim programlarına hâkim olamayışları, tecrübesiz olmaları, ideolojik yaklaşımları, pedagojik formasyon yetersizlikleri". Ders denetimi konusunda okul müdürlerinin uzman olmadıkları noktasında müfettişler en 
fazla, okul müdürlerinin denetim formasyonuna sahip olmamalarından veya bu konudaki yetersizliklerinden, değerlendirmede objektif olamamalarından ve öğretim programlarına hâkim olamamalarından bahsetmektedirler. Öğretmenlerin, okul idarecilerinin ve müfettişlerin bu konuda büyük ölçüde aynı fikirde oldukları görülmektedir.

Müfettişlerin bu konu ile ilgili açıklamalarına örnek olabilecek bazı ifadeler aşağıda yer almaktadır:

“...Okul çalışanlarının şikâyetlerinde müdürlerin bu konuda yetersiz oldukları, ideolojik bakış açısıyla yaklaştıkları, objektif davranmadıkları ifade edilmektedir."(M2)

“...Denetim uzmanlık gerektirir. Ders denetimi konusunda eğitim almadıklarından dolayı yetersiz olduklarını düşünüyorum."(M3)

“...Kesinlikle değil. Bu durumdan hem müdürler hem de öğretmenler şikâyetçidirler. Çünkü okul müdürleri denetimin ilke ve süreçlerinden öğretim programlarından haberdar değildir. Kişisel ilişkilere bakılarak değerlendirme yapılabilmekte, siyasi ve ideolojik durumlar da denetimi tarafsız kılıyor."(M5)

"...Sürekli beraber çalıştıklarından ahbap, dost, eş, arkadaşlık, samimiyet ilişkileri geliştikçe denetimin objektifliği azalır."(M8)

\section{Ders Denetimlerinin Okul Müdürleri Tarafından Yapılmasının Olumlu Yönleri}

Ders denetimlerinin okul müdürleri tarafından yapılmasının olumlu yönlerine ilişkin öğretmen, okul idarecileri ve müfettişlerin görüşlerinin içerik analizi sonucu elde edilen temalar ve temalara ilişkin kodlar Tablo 5'te verilmiştir.

\section{Tablo 5.}

Ders Denetimlerinin Okul Müdürleri Tarafından Yapılmasının Olumlu Yönlerine iliş̧kin Görüşler.

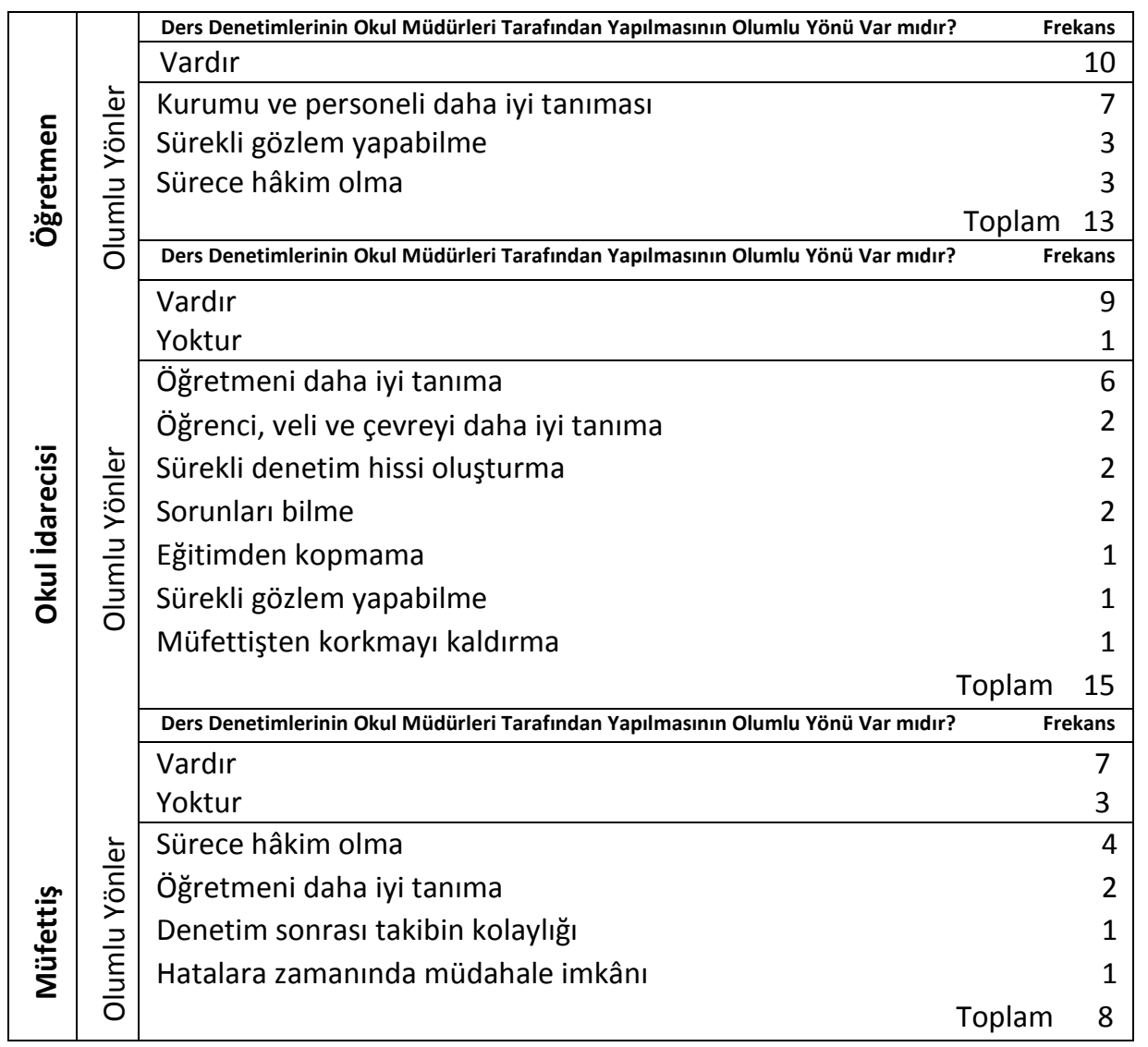


Tablo 5'e bakıldığında öğretmenler, ders denetimlerinin okul müdürleri tarafından yapılmasının olumlu yönleri olarak; "okul müdürlerinin kurumunu ve personelini daha iyi tanıması, okul müdürünün sürekli gözlem yapma imkânına sahip olması ve sürece hâkim olması" şeklinde görüş belirtmişlerdir. Öğretmenler ders denetimlerinin okul müdürleri tarafından yapılmasında olumlu yön olarak en fazla, okul müdürlerinin kurumunu ve öğretmenleri tanımasını önemsediklerini ifade etmektedirler.

Öğretmenlerin açıklamalarına örnek olabilecek bazı alıntılar aşağıda yer almaktadır:

" ...Okul müdürleri dışarıdan gelen birisine göre ön bilgilere daha fazla vakıftır. Kurumu, personeli daha iyi tanıyıp biliyordur."(Ö1)

"... Sürekli öğretmenle birlikte olduğundan öğretmeni gözlemleme, daha iyi tanıma şansı var ve bu en büyük avantajdır. Oysa müfettiş denetimi en fazla bir gün (1-2 ders saati) olacak şekildedir."(Ö2)

“... Sürekli bizi gözlemleme imkanı olduğundan dolayı bu olumlu bir yöndür."(Ö4)

“... Müdür öğretmeni yıl içerisinde tanıyor, davranışlarımızı biliyor ve denetimde bunları göz önünde bulundurabilir."(Ö5).

"... Bize müfettiş geldiğinde şöyle derdik. "Inşallah bana müfettiş şu sınıfta gelir, diğer sınıfta gelmez" derdik." (Ö7)

Okul idarecileri, ders denetimlerinin okul müdürleri tarafından yapılmasının olumlu yönleri hakkında; "Okul müdürlerinin kurumunu ve personelini daha iyi tanıması, okul müdürünün sürekli gözlem yapma imkânına sahip olması ve sürece hâkim olması" şeklinde görüşlerini ifade etmişlerdir. Okul idarecileri ders denetimlerinin okul müdürleri tarafından yapılmasında olumlu yön olarak en fazla, okul müdürlerinin öğretmenleri, öğrencileri, velileri ve çevreyi daha iyi tanımaları olarak ifade etmişlerdir. Okul idarecilerinden biri olumlu bir yan olmadığını ifade etmektedir.(Oi4)

Okul idarecilerinin bu konu ile ilgili açıklamalarına örnek olabilecek bazı alıntılar aşağıda sunulmuştur:

“...Müdürün çevre koşullarını tanıması ve dikkate alması, öğrenci ve velilerin genel profilleri hakkında bilgi sahibi olması, öğretmenle sürekli birlikte olmasından dolayı öğretmenlerin yeterlilikleri hakkında daha fazla bilgi sahibi olması..."(Oi1)

"...Bence olumlu yönü yoktur. Şu anda denetim gerektiği şekliyle yapılmamaktadır."(Oi4)

“...Müdür gün boyu okulda olduğundan öğretmeni sürekli gözlemleyebilir."(Ö6)

“...Okul müdürü sürekli okulda olduğundan denetim de sürekli oluyor. Müfettişin denetimi 1-2 gün olduğundan çok kısa oluyor."(Oig)

Müfettişler, ders denetimlerinin okul müdürleri tarafından yapılmasının olumlu yönleri hakkında; "sürece hâkim olma, öğretmeni daha iyi tanıması, denetim sonrası takibin kolaylığı, hatalara zamanında müdahale etme imkânı" durumlarını olumlu yön olarak ifade etmişlerdir. Müfettişler ders denetimlerinin okul müdürleri tarafından yapılmasında olumlu yön olarak en fazla, okul müdürlerinin sürece hâkim olmaları ve öğretmenleri daha iyi tanımalarını görmektedirler. Müfettişlerden üçü ise olumlu bir yan olmadığını ifade etmektedirler.(M5, M7, M10)

Bazı müfettişlerin bu konu ile ilgili açıklamalarına örnek olabilecek ifadelerine aşağıda yer verilmiştir:

“...Okul müdürleri sürecin doğrudan takipçisi oldukları, birebir gözlem yapma fırsatı buldukları, çalışmaları yerinde ve zamanında izleme ve değerlendirmede bulunabilecekler, hatalı çıktılara doğrudan ve zamanında müdahale imkânı olduğundan birtakım avantajlara sahiptir."(M2)

"...Denetimi yapıp takip etme imkânı var ancak müfettişlerin ki yok."(M4)

"...Memnun olanı görmedim, denetim yeterlikleri yok, öğretmeni tanımayan müdürler var."(M5)

“...Amatörce yapılması halinde bu öğretmene, eğitim öğretime, kuruma zarar."(M6)

"Olumlu yönü yoktur. Denetim elemanı her branşa dair denetim esaslarından haberdar olması gerektiği ve profesyonelce yapması gerekeceği için okul müdürlerinde bu yeterlilikler olmadığından dolayı bu olumsuzdur."(M7) 
Öğretmenler, okul idarecileri ve müfettişler, ders denetimlerinin okul müdürlerince yapılmasında olumlu yön olarak genelde okul müdürlerinin öğretmenlerini daha iyi tanıdıklarını ve öğretmeni süreç içerisinde izleyebilme imkânına sahip olduklarını belirtmişlerdir.

\section{Ders Denetimlerinin Okul Müdürleri Tarafindan Yapılmasının Olumsuz Yönleri}

Ders denetimlerinin okul müdürleri tarafından yapılmasının olumsuz yönlerine ilişkin öğretmen, okul idarecileri ve müfettişlerin görüşlerinin içerik analizi sonucu elde edilen temalar ve temalara ilişkin kodlar Tablo 6’da verilmiştir.

Tablo 6.

Ders Denetimlerinin Okul Müdürleri Tarafından Yapılmasının Olumsuz Yönlerine Ilişsin Görüşler.

\begin{tabular}{|c|c|c|c|}
\hline \multirow{8}{*}{ مْ } & \multirow{8}{*}{ 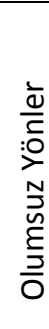 } & Ders Denetimlerinin Okul Müdürleri Tarafından Yapılmasının Olumsuz Yönü Var mıdır? & Frekans \\
\hline & & Vardır & 10 \\
\hline & & Değerlendirmede objektif olamama & 9 \\
\hline & & Denetim formasyonunun yetersiz oluşu & 3 \\
\hline & & Program ve pedagojik formasyon yetersizlikleri & 2 \\
\hline & & Öğretimsel lider olamama & 1 \\
\hline & & Toplam & 15 \\
\hline & & Ders Denetimlerinin Okul Müdürleri Tarafından Yapılmasının Olumsuz Yönü Var mıdır? & Frekans \\
\hline \multirow{8}{*}{$\begin{array}{l}\overline{\bar{y}} \\
\frac{d}{2} \\
\frac{\pi}{0} \\
\overline{\bar{z}} \\
\bar{z}\end{array}$} & \multirow{8}{*}{ 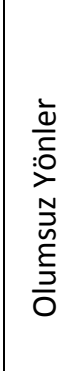 } & Vardır & 10 \\
\hline & & Değerlendirmede objektif olamama & 10 \\
\hline & & Denetim formasyonunun yetersiz oluşu & 5 \\
\hline & & Denetim sonucunda çatışma çıkması & 4 \\
\hline & & Öğretmenle sürekli aynı ortamı paylaşma & 2 \\
\hline & & Denetimin ağırlığının azalması & 1 \\
\hline & & Karar vermede baskı altında kalma & 1 \\
\hline & & Öğretmenlerin idareye yakınlaşmaya çalışması & 1 \\
\hline \multirow{14}{*}{ 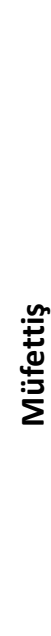 } & \multirow{14}{*}{ 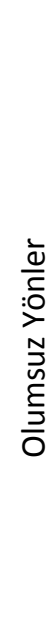 } & Toplam & 24 \\
\hline & & Ders Denetimlerinin Okul Müdürleri Tarafından YapıImasının Olumsuz Yönü Var mıdır? & Frekans \\
\hline & & Vardır & 10 \\
\hline & & Değerlendirmede objektif olamama & 8 \\
\hline & & Denetim formasyonunun yetersiz oluşu & 2 \\
\hline & & Alan hâkimiyetinin olmayışı & 2 \\
\hline & & Denetim sonucunda hizipleşmelerin olması & 2 \\
\hline & & Müdürün otorite olarak görülmemesi & 2 \\
\hline & & Öğretmenin zarar görmesi & 1 \\
\hline & & Tarafların birbirlerinin açıklarını bilmeleri & 1 \\
\hline & & Denetimin baskı amaçlı kullanılması & 1 \\
\hline & & Kurum kültürünü bozma & 1 \\
\hline & & Önyargı & 1 \\
\hline & & Toplam & 21 \\
\hline
\end{tabular}

Tablo 6'da görüldüğü gibi öğretmenler, ders denetimlerinin okul müdürleri tarafından yapılmasının olumsuz yönleri olarak; "Okul müdürlerinin değerlendirmede objektif olamamaları, okul müdürlerinin denetim formasyonunun yetersiz oluşu ve öğretimsel lider olamamaları, müdürlerin öğretim programlarındaki ve pedagojik formasyon alanlarındaki yetersizlikleri”ni görmektedirler. Öğretmenler ders denetimlerinin okul müdürleri tarafından yapılmasının olumsuz yönlerini ifade ederken en fazla, okul müdürlerinin objektif olamamalarını, denetim formasyonlarının yetersizliğini ve öğretim programları ile pedagojik formasyon alanlarındaki yetersizliklerini vurgulamışlardır. Görüşlerine 
başvurulan 10 öğretmenden dokuzu okul müdürlerinin ders denetimleri sürecinde öğretmenlerin performanslarının değerlendirilmesinde subjektif davrandıklarını belirtmişlerdir.

Öğretmenlerin açıklamalarına örnek olabilecek bazı alıntılar aşağıda yer almaktadır:

“...Subjektif olma durumu söz konusudur. Aynı durumu yaşayan iki öğretmen düşünelim. ikisi de aynı sonuca maruz kalması gerekirken aynı durumlarla karşı karşıya kalmayabiliyorlar."(Ö1)

"... Yani sadece şu ortaya çıkıyor. Müdürün yanlı davranması durumunda sıkıntı çıkıyor. Denetim disiplinine ilişkin yetersizliklerinin olduğunu düşünüyorum."(Ö2)

"... Bence en büyük olumsuzluk onların uzun süre idarecilik yaptıklarından dolayı sınıfa öğretim programına uzak olmalarıdır diye düşünüyorum. Kişisel problemlerin denetime yansıması, kişisel ilişkilerin puanlamaya yansıması olumsuzluklardandır." (Ö4)

"... Biraz kişisel mevzusu olan öğretmenlerimiz varsa tarafsızllk bitiyor, objektiflik bitiyor, yanlılık ve sübjektiflik devreye giriyor. Alan ve pedagojik yetersizliği denetimi sağlıksızlaştırıyor. Performans puanındaki adaletsizlikler ya da öğretmenin algıladığı adaletsizlik kurumda huzursuzluğa yol açmakta ve iklim bozulmaktadır."(Ö5)

"... Öğretmen adaletsizlik algılarsa bu öğretmenin işini olumsuz etkileyecek ve kurumda çalışan öğretmenler arasında çatışmalara sebep olabilir." (Ö7)

"... Vardır. Denetimin şahsileştirilmesi kurum içinde huzursuzluğa neden olur." (Ö8)

"...Tek düşündüğüm olumsuzluk okul müdürlerinin yanlı davranma durumlarıdır. Değerlendirme sonuçlarının öğretmenler arasında oluşturduğu huzursuzluk, okul iklimini olumsuz etkilenmesi ve akabinde öğretmen performansının düşmesi..."(Ö10)

Okul idarecileri, ders denetimlerinin okul müdürleri tarafından yapılmasının olumsuz yönleri olarak; "okul müdürlerinin değerlendirmede objektif olamamaları, denetim formasyonlarının yetersiz oluşu, denetim sonucunda müdür-öğretmen/öğretmen-öğretmen arasında çatışma çıkması, öğretmenle sürekli aynı ortamı paylaşmanın değerlendirmeyi olumsuz etkilemesi, denetimden yüksek puan alabilmek için öğretmenlerin idareye yakınlaşmaya çalışmaları, okul müdürlerinin karar vermede baskı altında kalmaları, denetimin ağırı̆̆ının azalması"nı ifade etmişlerdir. Okul idarecileri ders denetimlerinin okul müdürleri tarafından yapılmasında en fazla, okul müdürlerinin değerlendirmede objektif olamamalarını, okul müdürlerinin denetim formasyonlarının yetersiz oluşunu ve denetim sonucunda müdüröğretmen/öğretmen-öğretmen arasında çatışma çıkması durumunu olumsuz yön olarak değerlendirmişlerdir. Okul müdürlerinin ders denetimi yapmalarındaki olumsuz yönlere ilişkin görüşlerin oranına bakıldığında okul idarecilerinin olumsuzluk bildiren görüşlerinin öğretmen ve müfettişlerin olumsuzluk bildiren görüşlerinden daha fazla olduğu görülmektedir.

Okul idarecilerinin bu konu ile ilgili açıklamalarına örnek olabilecek bazı alıntılar aşağıda verilmiştir:

"...Denetimi yapan kişinin sürekli denetmenlerle aynı ortamda olması iletişimi kesintiye uğratır, gergin bir orta yaratır, kayırmacılık söz konusu olur, denetlenenlerin yaranmışlık davranışları sergilemelerine neden olur, denetime ilişkin insanlar nazarındaki önemli olan yerin kıymetini azaltır."(Oi2)

"...Okul müdürleri öğretmenlerini daha önceden tanıdıklarından dolayı denetimde ön yargılı davranıyorlar. Objektif olamıyorlar. Ayrıca öğretmenlik uygulamalarına uzak kaldıklarından okul müdürlerinin denetimlerinin yetersiz olduğunu düşünüyorum. Yani denetledikleri alandan bihaberler."(Oi4)

“...Yüz yüze bakılması durumu söz konusu olduğundan söylenmesi gerekli, yapılması gerekli uyarıları iletişimi bozmamak adına söyleyemeyebilirler..."(Ö6)

Müfettişler, ders denetimlerinin okul müdürleri tarafından yapılmasının olumsuz yönleri hakkında; okul müdürlerinin değerlendirmede objektif olamamaları, okul müdürlerin denetim formasyonlarının yetersiz oluşu, alana hâkim olamayışları, denetim sonunda hizipleşmelerin olduğu, müdürün öğretmenler tarafından otorite olarak görülmemesi, denetleyen ve denetlenen tarafların birbirinin açıklarını bilmesi, öğretmenin denetim sonunda zarar görmesi, denetimin baskı unsuru olarak kullanılması, müdür denetimi 
sonunda kurum kültürünün bozulması, denetimin önyargı ile yapılması" durumlarını ifade etmişlerdir. Müfettişler ders denetimlerinin okul müdürleri tarafından yapılmasında olumsuz yön olarak en fazla, okul müdürlerinin değerlendirmede objektif davranamadıklarını, denetim formasyonu yetersizliklerini ve alana hâkim olmayışlarını vurgulamışlardır.

Müfettişlerin bu konu ile ilgili açıklamalarına örnek olabilecek ifadelerine aşağıda yer verilmiştir:

“...Pozitif ayrımcılık yapabilir bu da kurumda hizipleşmeye, güvensizliğe sebep verebilir.”(M1)

"...Bazen denetim baskı unsuru olarak kullanılıyor. Adil davranamayabiliyor. Çünkü kendine muhalif olanlara karşı adil olmayan davranışlar sergilenebiliyor."(M4)

Öğretmenler, okul idarecileri ve müfettişler, okul müdürlerinin ders denetimi yapmalarının olumsuz yönü olarak öncelikle okul müdürlerinin subjektif davranma durumlarını belirtmişlerdir. Ayrıca okul müdürlerinin denetim formasyonuna sahip olmamaları veya bu konudaki yetersizlikleri bir diğer olumsuz yön olarak değerlendirilen boyut olarak ortaya çıkmıştır.

\section{Ders Denetimlerinin Müfettişler Tarafından Yapılmasının Olumlu Yönleri}

Ders denetimlerinin müfettişler tarafından yapılmasının olumlu yönlerine ilişkin öğretmen, okul idarecileri ve müfettişlerin görüşlerinin içerik analizi sonucu elde edilen temalar ve temalara ilişkin kodlar Tablo 7'de verilmiştir. 
Tablo 7.

Ders Denetimlerinin Müfettişler Tarafından Yapılmasının Olumlu Yönlerine Iliş̧kin Görüşler.

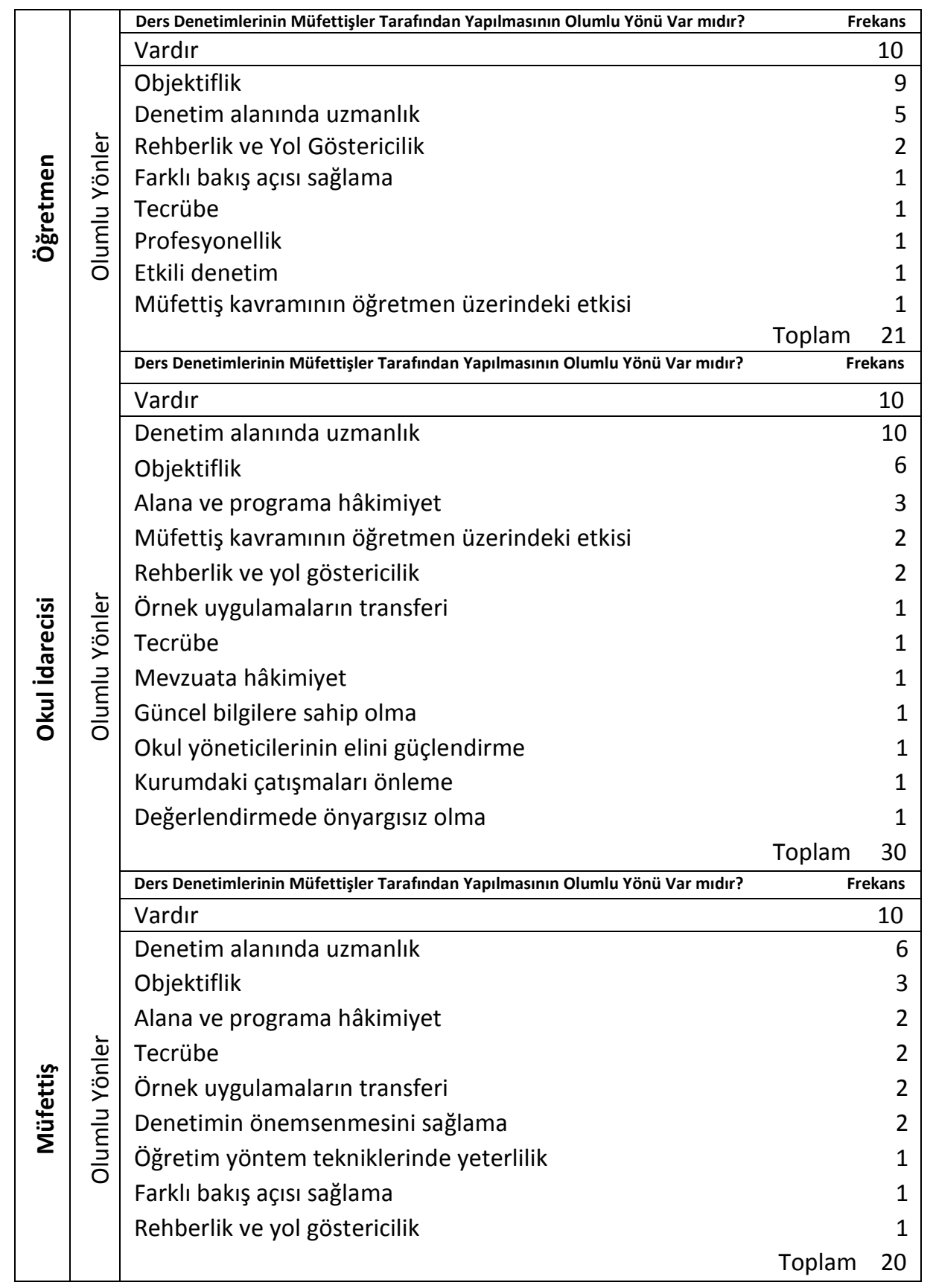

Tablo 7’de görüldüğü üzere öğretmenler, ders denetimlerinin müfettişler tarafından yapılmasının olumlu yönleri olarak; "Müfettişlerin denetim ve değerlendirmede objektif oldukları, denetim alanında uzman oldukları, rehberlik ve yol göstericilik yapabildikleri, kuruma ve öğretmene farklı bakış açıları sunabildikleri, tecrübeli ve profesyonel oldukları, etkili denetim yaptıkları, müfettiş kavramının öğretmen üzerindeki etkisinin eğitim öğretim sürecine olumlu yansıdığı” nı ifade etmişlerdir. Öğretmenler, denetim ve değerlendirme konusunda okul müdürlerinin objektif olmadıklarına ilişkin katılım göstermelerine karşın (10/10), müfettişlerin objektif oldukları yönünde görüş bildirmişlerdir (6/10). 
Öğretmenlerin açıklamalarına örnek olabilecek bazı alıntılar aşağıda sunulmuştur:

"...Bence daha objektif denetim yaparlar. Uzmanlıkları bulunduğundan dolayı daha nitelikli denetim olmaktadır."(Ö1)

"...Müfettişlerin denetimlerinde rehberlik ve akabindeki denetim öğretmene yol gösterici olmaktaydı, eksikliklerimizi fark etme noktasında bizi aydınlatmaktaydı. Müfettiş gördüğ̈̈yle denetlediği için kişisel davranmaz daha objektif ve yansızdır."(Ö2)

"...En azından rehberlik yapılıyor, yol gösteriliyor, olumlu eleştiri yapılıyor. Müfettiş kavramının ağırlığı var ve bundan dolayı öğretmen kendini çalışmak zorunda hissedebiliyor. Müfettiş daha objektiftir."(Ö5)

"...Hani dışarıdan gelen bir eleman olduğundan ve denetim alanında uzman olduklarına inandığım için müfettişler tarafından yapılmasının daha uygun olduğunu düşünüyorum."(Ö6)

"...Sürekli denetim yaptıkları için daha profesyoneldirler."(Ö8)

"...Daha objektif oluyorlar, işin ehli olduklarından daha bilimsel denetim yapıyorlar."(Ö10)

Okul idarecileri, ders denetimlerinin müfettişler tarafından yapılmasının olumlu yönleri olarak; "Müfettiş̧erin denetim alanında uzmanlıklarının bulunduğunu, objektif olduklarını, alana ve programa hâkimiyetlerinin bulunduğunu, müfettiş kavramının öğretmen üzerindeki olumlu etkisinin olduğunu, rehberlik ve yol göstericilik rollerinin olduğunu, örnek uygulamaları bir yerden başka bir yere nakletme gibi bir işlevi yerine getirdiklerini, tecrübeli olduklarını, mevzuata hâkimiyetlerinin olduğunu, güncel bilgilere sahip ve değerlendirmede önyargısız olduklarını, denetim sonunda değerlendirme kaynakı çıkacak çatışmaları önlediklerini, okul yöneticilerinin elini güçlendirme gibi bir işlevlerinin olduğunu" belirtmişlerdir. Okul idarecilerinin denetim ve değerlendirme konusunda okul müdürlerinin objektif olmadıklarına ilişkin büyük oranda görüş belirtmelerine karşın (9/10) yine büyük oranda müfettişlerin objektif olduklarını da vurgulamışlardır (9/10). Okul idarecileri ders denetimlerinin müfettişler tarafından yapılmasının olumlu yönleri olarak en fazla, müfettişlerin denetim alanında uzmanlıklarının olmasını, objektif olmalarını, alana ve programa hâkim olmalarını vurgulamışlardır.

Okul idarecilerinin açıklamalarına örnek olabilecek alıntılar aşağıda verilmiştir:

“...Değişiklikleri sürekli takip ederler, olumlu eğitim uygulamalarını arının diğer çiçeklere toz taşıdığı gibi başka kurum ve öğretmenlere taşır, bu da öğretmende motivasyonu arttırır."(Oi1)

"...Müfettişler alana hâkim, belirli kademelerde (öğretmenlik, idarecilik vb.)çalışmış, sınavlara girmiş kazanmış, denetim yeterliliğini elde etmiş kişilerdir. Müfettiş unvanına öğretmenlerin yüklediği anlam ve verdiği değer daha fazla olduğundan ders denetimlerinin müfettişler tarafından yapılması daha faydalıdır."(Oi2)

"...Denetimin içerisine şahsilik, ön yargı vs. katmaz. Objektif, güvenilir bir denetim gerçekleştirilir. Kullandıkları denetim rehberi gibi materyallerle denetimin geçerliliği ve güvenirliği artar."(Oi4)

"...Değerlendirme anlamında profesyonel olduklarını düşünüyorum."(Oi5, Oi7)

"...Okul idaresini rahatlatıyor. Çünkü müfettişin denetim yapacak olması öğretmene karşı müdürün elini güçlendiriyor.... Eve dışarıdan gelen misafir için genel temizliğin yanında ayrıntılı temizliğe girildiği gibi okullarımızda da müfettiş geleceği zaman en ince detaya kadar çalışma yapıyorlar."(Oí)

Müfettişler, ders denetimlerinin müfettişler tarafından yapılmasının olumlu yönleri olarak; "Müfettişlerin denetim alanında uzmanlıklarının bulunduğunu, objektif olduklarını, alana ve programa hâkimiyetlerinin bulunduğunu, tecrübeli olduklarını, örnek uygulamaları bir yerden başka bir yere nakletme gibi bir işlevi yerine getirdiklerini, denetimin önemsenmesini sağladıklarını, rehberlik ve yol göstericilik rollerinin olduğunu, kuruma ve öğretmene farklı bakış açıları sunduklarını, öğretim yöntem ve tekniklerinde yeterli olduklarını" belirtmektedirler. Müfettişler, ders denetimlerinin müfettişler tarafından yapılmasının olumlu yönleri olarak en fazla, müfettişlerin denetim alanında uzmanlıklarının olmasını, objektif olmalarını, alana ve programa hâkim olmalarını vurgulamışlardır.

Müfettişlerin bu konu ile ilgili açıklamalarına örnek olabilecek ifadelerine aşağıda yer verilmiştir:

“...Tarafsızlık bir diğer olumlu yöndür."(M4) 
"...Bir defa uzman oldukları için otorite olarak kabul ediliyorlar öğretmenlerce. Kabul gören, değer gören bir ağırlığı var. ...bilgi, tecrübe ve denetim yeterliliği vardır."(M5)

"Her müfettiş kendi branşına dair program esaslarına hâkimdir. Olumsuz uygulamaları tespit edebilir. Diğer okul-kurumlardan edindiği olumlu yönleri denetimini yaptığı öğretmenlerle paylaşabilir. Denetime iliş̧in bilimsel süreçleri uygulayabilir."(M7)

"...Müfettişler seçilmiş ve alanında uzman kişsilerdir. Hem alandan gelmiş olmaları, bazılarının eğitim yönetimi alanında lisans, yüksek lisans ve doktora eğitimlerinin bulunması, tecrübeli olmaları..."(M9)

Öğretmenler, okul idarecileri ve müfettişler, ders denetimlerinin müfettişler tarafından yapılmasının üzerinde fikir birliğinde bulundukları olumlu yönleri olarak; müfettişlerin denetim alanında uzman oldukları, objektif oldukları ve alana ve programa hâkim olduklarını ifade ettikleri görülmektedir.

\section{Ders Denetimlerinin Müfettişler Tarafından Yapılmasının Olumsuz Yönleri}

Ders denetimlerinin müfettişler tarafından yapılmasının olumsuz yönlerine ilişkin öğretmen, okul idarecileri ve müfettişlerin görüşlerinin yapılan içerik analizi sonucu elde edilen temalar ve temalara ilişkin kodlar Tablo 8'de verilmiştir.

\section{Tablo 8.}

Ders Denetimlerinin Müfettişler Tarafından Yapılmasının Olumsuz Yönlerine iliş̧kin Görüşler.

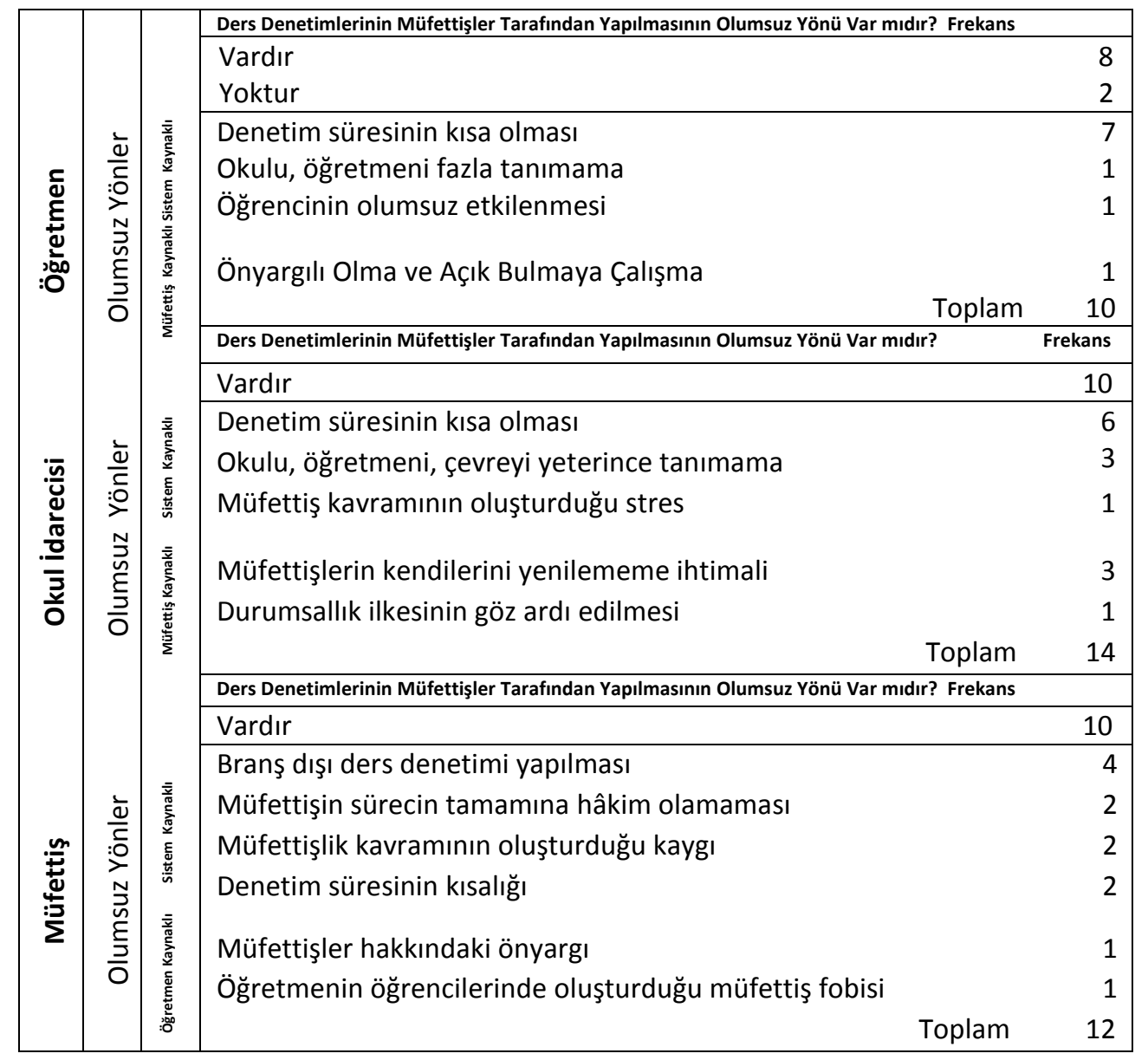

Tablo 8'e bakıldığında öğretmenlerin, ders denetimlerinin müfettişler tarafından yapılmasının olumsuz yönleri hakkındaki düşüncelerinin müfettiş kaynaklı olumsuzluklar ve sistem kaynaklı olumsuzluk şeklinde iki tema altında incelendiği görülmektedir. Sistem kaynaklı olumsuz yönler; 
"denetim süresinin kısa olması, müfettişlerin okulu ve öğretmeni fazla tanımaması, dışarıdan birinin denetim için gelmesi durumunda öğrencilerin olumsuz etkilenmesi" dir. Müfettiş kaynaklı olumsuz yönler ise "müfettişlerin önyargılı olması ve açık bulmaya çalışması" şeklinde ifade edilmiştir. Öğretmenlerin olumsuz yön olarak belirttikleri durumlardan sistem kaynaklı olanlar doğrudan müfettişin kendisi ile ilgili olmayan durumlar olarak değerlendirilebilir. Müfettişten kaynaklı olumsuzluklar ise sadece müfettişlerin ön yargılı olmaları ve açık bulmaya çalışmaları olarak ortaya çıkmıştır. Bu olumsuzluk sadece bir öğretmen tarafından ifade edilmiştir.(Ö10)

Öğretmenlerin açıklamalarına örnek olabilecek bazı alıntılar aşağıda sunulmuştur:

"...Denetimin çok kısa bir sürece sığdırılması olumsuz bir yön olarak ortaya çıkmaktadır."(Ö2)

“...40-80 dakika gibi kısa sürelerde yapılırsa bu olumsuz yön olarak çıkıyor."(Ö3)

“...Ben rastlamadım. Tecrübeli olduklarını düşünüyorum. Denetim kısa süre de olsa bu süre zarfında öğretmenin birçok yönünün tespit edilebileceği kanaatindeyim."(Ö5)

“...Vardır. O da süredir. 1-2 ders saati gibi bir sürede değerlendirme yetersiz olur. Denetim saatinde olduğun sınıfın performansı öğretmenin bir yıllık sergilediği emeği ortaya koymada yetersizdir. Dokuz sınıfa giriyorum. Her sınıf birbirinden çok farklı."(Ö7)

“...Eğer müfettiş yetkinse ve kişisel problemleri yoksa hiçbir sıkıntısı yoktur."(Ö8)

"...Sürenin kısa olması öğretmeni yeterince tanımamasına neden oluyor. Yılda en azından birkaç kez gelmiş olsa idi öğretmen ve sınıftaki değişimleri daha iyi gözlemleyebilirdi."(Ög)

"...Öğretmene karşı önyargı, açık bulmaya çalışma tutumu bence olumsuz yönlerdir. Gördüklerimin içerisinde \% 20'yi geçmez bunlar."(Ö10)

Okul idarecilerinin, ders denetimlerinin müfettişler tarafından yapılmasının olumsuz yönleri hakkındaki düşünceleri de müfettiş kaynaklı olumsuzluklar ve sistem kaynaklı olumsuzluk şeklinde iki tema altında toplanmıştır. Sistem kaynaklı olumsuz yönler; "Denetim süresinin kısa olması, müfettişlerin okulu, öğretmeni, çevreyi yeterince tanımaması, müfettiş kavramının oluşturduğu stres" tir. Müfettiş kaynaklı olumsuzluklar ise sadece müfettişlerin kendilerini yenilememe ihtimallerinin olması ile durumsallık ilkesinin göz ardı edilmesi olarak ortaya çıkmıştır. Okul idarecilerinin belirttiği olumsuz yönlerin daha çok sistem kaynaklı olumsuzluklar olduğu görülmektedir.

Okul idarecilerinin açıklamalarına örnek olabilecek bazı alıntılar aşağıda yer almaktadır:

“...Teknolojiyi ve programı takip eden bir öğretmene teknoloji ve program açısından kendini yenilemeyen müfettişin gelerek demode isteklerde bulunması işini iyi yapan öğretmenin motivasyonunu düşürecektir. Bu da kaliteyi düşürecektir."(Oi2)

"...Denetimler kısa süreli olduğu için personeli yeterince tanıma, eğitsel ürünleri tüm yönleriyle değerlendirme mümkün olmayabiliyor."(Oi3)

"...Müfettişler tarafından durumsallık ilkesinin göz önünde bulundurulmaması bir olumsuzluktur."(Oi5)

“...Şunu söyleyeyim, öğretmenlerin bütün bir yıl yaptığı çalışmalar bu kısa süre içerisinde görülememektedir."(Oi7)

“...Öğretmenler gözündeki müfettiş kavramının yarattığı stres bir diğer olumsuzluktur."(Oi8)

Müfettişlerin, ders denetimlerinin müfettişler tarafından yapılmasının olumsuz yönleri hakkındaki düşünceleri de sistem kaynaklı olumsuzluklar ve öğretmen kaynaklı olumsuzluk şeklinde iki tema altında incelenmiştir. Sistem kaynaklı olumsuz yönler olarak; "Müfettişlerin branşları dışındaki derslerin denetimini yapmaları, müfettişlerin eğitim öğretim sürecinin tamamına hâkim olamamaları, müfettişlik kavramının oluşturduğu kaygı, denetim süresinin kısalığı"nı ifade etmektedirler. Öğretmen kaynaklı olumsuzluklar ise "Müfettişler hakkındaki önyargılar ile öğretmenin öğrencileri üzerinde oluşturduğu müfettiş fobisi"dir.

Müfettişlerin bu konu ile ilgili açıklamalarına örnek olabilecek bazı görüşlerine aşağıda yer verilmiştir: 
“...Müfettişler bir korku aracı olarak öğrencilere gösterildiği için ve öğretmenlerde geneldeki bir olumsuz bakış yüzünden bir olumsuzluk vardır."(M1)

"...Eğitim sürecinin tamamını gözlemleme şansı azdır. Kurumun, sınıfın nereden nereye geldiği konusunda yeterli bilgiye sahip olmaması, müfettiş öğretmen arası Resmî diyalogdan kaynaklı öğretmen heyecan-kaygı düzeyinin denetime olumsuz etki edecek faktörler olması."(M2)

"Müfettişlerin branşı dışındaki derslerin denetimine girmeleri yeterli verimin elde edilmesine mani olmaktadır."(M3)

"...Olumsuz tarafı çok azdır. O da öğretmen üzerinde oluşan müfettiş kavramının yarattığı kaygı..."(M8)

Öğretmenler, okul idarecileri ve müfettişlerin, ders denetimlerinin müfettişler tarafından yapılması üzerinde fikir birliğinde bulundukları olumsuz yönler genelde ders denetim sürelerinin kısa olması, okula çok az geldikleri için müfettişlerin okulu, öğretmeni ve çevreyi fazla tanımamaları, müfettişlerin eğitim öğretim sürecine hâkim olamamaları, bunun sadece rehberlik ve denetim olduğu gün ve saatlerle sınırlı olmasıdır. Katılımcılar müfettiş kaynaklı olumsuz yönlerle ilgili olarak sadece üç nokta üzerinde durmuşlardır. Bunlar: müfettişlerin kendilerini yenilememe ihtimalinin bulunması (3/10), durumsallık ilkesini göz ardı etmeleri (1/10), önyargılı olma ve açık bulmaya çalışmalarıdır (1/10).

\section{Ders Denetimlerinin Kim ya da Kimler Tarafından Yapılması Gerektiği}

Ders denetimlerinin kim ya da kimler tarafından yapılması gerektiğine ve nedenine ilişkin öğretmen, okul idarecileri ve müfettişlerin görüşlerinin yapılan içerik analizi sonucu elde edilen temalar ve temalara ilişkin kodlar Tablo 9'da verilmiştir. 
Tablo 9.

Ders Denetimlerinin Kim Ya da Kimler Tarafından Yapılması Gerektiğine Illişkin Görüşler.

\begin{tabular}{|c|c|c|c|c|c|}
\hline & & & Ders Denetimlerini Kim/Kimler Yapmalı? & Frek & \\
\hline & & & Müfettiş & & 6 \\
\hline & & & Okul müdürü & & 2 \\
\hline & & & Müfettiş ya da okul müdürü & & 1 \\
\hline & & & Kariyer gurubundan öğretmenler & & 1 \\
\hline & & & Toplam & & 10 \\
\hline & $\xi$ & $\stackrel{\ddot{m}}{ \pm}$ & Öğretmenlik deneyimi vardır & & 3 \\
\hline & 递 & 崖 & Denetim işinde uzmandır & & 3 \\
\hline & & $\underset{c}{\geq}$ & Alana hâkimdir & & 2 \\
\hline & & $\frac{0}{2}$ & & Toplam & 8 \\
\hline & & 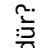 & Süreci görebildiği için & & 1 \\
\hline & & 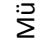 & Toplam & & 1 \\
\hline & & $\frac{\pi}{0}$ & Ders Denetimlerini Kim/Kimler Yapmalı? & Freka & \\
\hline 吾 & & 2 & Müfettiş & & 4 \\
\hline ปั่ & & & Okul müdürü & & 3 \\
\hline $\bar{n}$ & & & Müfettiş ya da okul müdürü & & 1 \\
\hline$\stackrel{\mathbb{E}}{\varepsilon}$ & & & Özel kuruluşlar & & 1 \\
\hline$\overline{\frac{2}{0}}$ & & & Bağımsız kişiler ve müdür & & 1 \\
\hline$=$ & "ूu & & & Toplam & 10 \\
\hline$\frac{\pi}{0}$ & $\frac{1}{0}$ & $\stackrel{m}{m}$ & Denetim işinde uzmandır & & 2 \\
\hline$\frac{1}{0}$ & $\overline{\bar{J}}$ & 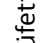 & Dış denetim işe ciddiyet katar & & 2 \\
\hline$\overline{\mathscr{\sigma}}$ & ठ̌ & $\sum_{c}^{\infty}$ & Öğretmeni dikkatli kılar ve kontrolü sağlar & & 1 \\
\hline$\frac{\bar{\omega}}{\pi}$ & & $\frac{0}{0}$ & Alana hâkimdir & & 1 \\
\hline$\underline{\underline{\varepsilon}}$ & & $\begin{array}{l}z \\
n .\end{array}$ & & Toplam & 6 \\
\hline $\mathcal{E}$ & & 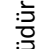 & Öğretmeni daha iyi tanır & & 1 \\
\hline$\underset{c}{\underline{\varepsilon}}$ & & $\sum_{\subseteq}$ & Bütün süreci bilir & & 1 \\
\hline$\overline{\underline{E}}$ & & $\frac{0}{0}$ & & Toplam & 2 \\
\hline 旁 & & & Ders Denetimlerini Kim/Kimler Yapmalı? & Freka & \\
\hline$\stackrel{\mathscr{c}}{\mathrm{d}}$ & & & Müfettiş & & 5 \\
\hline n & & & Müfettiş ve okul müdürü & & 4 \\
\hline ڤั & & & Müfettiş, okul müdürü ve veli & & 1 \\
\hline & & & Toplam & & 10 \\
\hline & & & Dış kontrolü sağlar & & 3 \\
\hline & 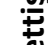 & 苛 & Denetim işinde uzmandır & & 2 \\
\hline & 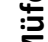 & $:_{\Sigma}^{2}$ & Alana hâkimdir & & 1 \\
\hline & & $\frac{\complement}{0}$ & Tecrübelidir & & 1 \\
\hline & & $\stackrel{0}{z}$ & Dış denetim saygınlığı arttırır & & 1 \\
\hline & & : & & Toplam & 8 \\
\hline & & $\sum$ & Denetimi sürece yaymak için & & 2 \\
\hline & & $\frac{\nwarrow}{0}$ & Müfettiş denetimi çok sık olmadığı için & & 2 \\
\hline & & $z$ & & Toplam & 4 \\
\hline
\end{tabular}


Tablo 9'da görüldüğü gibi ders denetimlerinin kim ya da kimler tarafından yapılmasının uygun olacağına ilişkin olarak öğretmenler, okul idarecileri ve müfettişler; denetimin en fazla müfettişler tarafından, daha sonra ise müdürler tarafından yapılmasının uygun olacağını ifade etmiş̧lerdir.

Öğretmenler, ders denetimlerinin kim/kimler tarafından yapılmasına ilişkin ağırlıklı olarak müfettişlerce $(6 / 10)$ ve okul müdürlerince $(2 / 10)$ yapılması gerektiğini belirtmişlerdir. Öğretmenlere ders denetimlerinin neden müfettişlerce yapılması gerektiği sorulduğunda, öğretmenler daha çok, müfettişlerin öğretmenlik deneyimlerinin bulunması, denetim işinde uzman olmaları ve alana hâkim olmalarını belirtmişlerdir. Öğretmenler, ders denetiminin müdürler tarafından yapılmasının uygunluğunu, okul müdürlerinin süreci görebilmeleri gerekçesine bağlamıştır.

Öğretmenlerin açıklamalarına örnek olabilecek bazı alıntılar aşağıda sunulmuştur:

“...Bir kere öğretmenlikte deneyim yaşamış olması lazım, öğretmenin gittiği yollardan bir kere gitmiş olması lazım, öğretmenin yaşadığı süreçleri yaşamış olması lazım. Denetlenecek alanlara hâkim, öğretmenliğin içinden gelen ama öğretmen unvanında olmayan müfettiş tarafından yapılmalıdır."(Ö2)

"...Müfettişler yapmalı ancak belirtilen niteliklere haiz olmak şartıyla yoksa denetim anlamsızlaşır."(Ö3)

“...Bence müfettişler yapmalı. Çünkü daha geliştirici, yol gösterici, olumlu eleştiri yapıcı oldukları kanaatindeyim."(Ö5)

“...Okul müdürleri yapmalı. Alanında yeterli hale getirilmeli, objektif olabilirlerse müdürün yapmasının daha faydalı olacağını düşünüyorum."(Ö7)

“...Bence okul müdürü yapsın. Çünkü öğretmeni uzun bir süreçte gözlemler, öğretmenin sınıfını daha iyi tanır. Denetim ve öğretim uzun bir süreçtir bunun sürekli gözlemlenmesi lazımdır."(Ö9)

"...Işsinin ehli olan müfettişler tarafından yapılmalıdır. Müfettişler okullara daha sık gelmelidir, öğretmeni tanımalıdır. Durumsalık ilkesine göre hareket etmelidir."(Ö10)

Okul idarecileri, ders denetimlerinin kim/kimler tarafından yapılmasına ilişkin ağırlıklı olarak müfettişlerce (4/10) veya okul müdürlerince (3/10) yapılması gerektiğini belirtmişlerdir. Okul idarecilerine, ders denetimlerinin neden müfettişlerce yapılması gerektiği sorulduğunda, okul idarecileri daha çok, müfettişlerin denetim işinde uzman olduklarından, dışarıdan birinin yaptığı denetimin işe ciddiyet katacağından, müfettiş denetiminin öğretmenin dikkatini arttıracağı ve öğretmeni kontrol altına alacağından, müfettişlerin alana hâkim olduklarından bahsetmişlerdir. Okul idarecileri, ders denetiminin okul müdürleri tarafından yapılmasının uygunluğunu ise öğretmeni daha iyi tanımasına ve bütün süreci bilmesine dayandırmışlardır.

Okul idarecilerinin açıklamalarına örnek olabilecek bazı ifadeler şu şekildedir:

“...Müfettişler denetim alanında eğitimli ve uzman kişilerdir. Böyle kişiler derse girdiklerinde olumlu bir denetim süreci oluşturacak bu da eğitsel başarıyı beraberinde getirecektir. Ayrıca denetçinin dışarıdan gelmesi daha ciddi bir denetimi sağlayacaktır, ..., öğretmen kontrol altında olacağından işini daha dikkatli ve özenli yapacaktır."(Oi2)

“...Bence müfettiş yapmalı ancak kesinlikle okul müdürünün görüşleri alınmalıdır. Öğretmen idare arasındaki ilişki, müdürün denetmen rolüne girmesiyle bozuluyor. idareci müfettiş ile öğretmen arasındaki iletişim köprüsü görevi üstlenmelidir."(Oi6)

“...Denetim alanında yeterli eğitim almış, iletişim yeterliliğine sahip, eğitsel-öğretimsel liderliği olan, cesur okul müdürleri tarafından yapılmasının daha doğru olacağı kanaatindeyim."(Oi8)

Müfettişler, ders denetimlerinin kim/kimler tarafından yapılmasına ilişkin ağılıklı olarak müfettişlerce (5/10) veya müfettiş ve okul müdürlerince birlikte (4/10) yapılması gerektiğini belirtmişlerdir. Müfettişlere, ders denetimlerinin neden müfettişlerce yapılması gerektiği sorulduğunda müfettişler daha çok, müfettişlerin dış kontrolü sağladıklarını, dış denetimin saygınlığı arttırdığını, alana hâkim, tecrübeli ve denetim işinde uzman olduklarını bu bakımdan ders denetimlerinin müfettişler tarafından yapılması gerektiğini ifade etmişlerdir. Müfettişler, ders denetiminin okul müdürü ve 
müfettişlerce birlikte yapılmasının uygunluğunu ise denetimin sürece yayılabilmesi ve müfettişlerin kurumlara denetim amacıyla sık gidememesi gerekçesine dayandırmışlardır.

Müfettişlerin açıklamalarına örnek olabilecek bazı beyanları aşağıda sunulmuştur:

“...Kesinlikle müfettişlerce. Özellikle denetimin o alandaki müfettişler tarafından yapılması gerekmektedir."(M3)

"...Aslında hem okul müdürü hem müfettiş birlikte yapmalıdır. Bu, süreç içerisine yayılmalı ve ikisi de farklı farklı zamanlarda yapmalıdırlar. Okul müdürünün duygusalığı ile müfettiş denetimindeki süre kısalığının olumsuzlukları bu yolla engellenecektir."(M4)

"...Müfettişler gerçekleştirmelidir. Çünkü denetim elemanı hem uzmandır, dışarıdan geldiği için saygınlığı vardır, farklı okullarda farklı uygulamaları gördüğü için daha tecrübelidirler. Oysa okul müdürü sadece kendi okulunu bilir diğer okulları bilemez."(M5)

"...Müfettişler denetimlerini belli aralıklarla yani yılda bir iki kez değil de daha fazla sayıda yapmalı. Onun dışındaki zamanlarda müdürler okulda bulunduklarından dolayı sürekli bir kontrol yapabilirler."(M8)

\section{Sonuç, Tartışma ve Öneriler}

\section{Ders Denetimlerinin Gerekliliği}

Araştırma sonucunda ders denetimlerinin yapılmasının gerekli olduğu öğretmen, okul idarecileri ve müfettişlerce ifade edilmiştir. Denetime doğrudan muhatap olan öğretmen ve okul idarecileri ile müfettişlere göre ders denetimlerinin yapılmasının örgütsel bir zorunluluk olduğu ortaya çıkmışır. Memduhoğlu (2012) tarafından öğretmen, okul idarecileri, eğitim denetmenleri ve öğretim üyelerinin katılımıyla yapılan araştırma sonucunda da eğitim denetiminin gerekliliğinin katılımcıların çoğu tarafından kabul edildiği ortaya çıkmışır. Özbaş (2002), araştırmasında müdür ve öğretmenlerin sınıf içi etkinliklerin denetimi ile ilgili bütün boyutların yapılması gerektiğine dair katılım gösterdiklerini ortaya koymuştur. Altun (2014) tarafından yapılan araştırmada ise denetleyenlerin daha sık denetim yapılması görüşünde oldukları, denetlenenlerin ise genel olarak daha seyrek denetim yapılması ya da denetim yapılmaması görüşünü yansıttıkları sonucuna ulaşılmıştır. Rizzo (2004) ise çalışmasında, öğretmenler ve denetçilerin, ideal denetimin ancak öğretmen ve denetçi arasında daha fazla iş birliği ile ve daha yakın aralıklarla yapılması durumunda gerçekleşeceğini ifade ettiklerini belirlemiştir. Denetim, öğretimin ve programın geliştirilmesi noktasında öğretmene yardım etmektir (Glickman, Gordon \& Ross, 2004). Öğretmenler için bir ihtiyaç olan denetim (Acheson\&Gall, 2011) aynı zamanda başarılı bir okul için gerekli olan tutkal gibidir (Glickman, 1990). Acar (2009) araştırmasında ders denetimine ilişkin okul yöneticilerinin, ders denetiminin mesleki gelişmelerine katkı sağladığını, iyi düzenlenmesi halinde hem okula, hem öğretmene hem de kendilerine faydalı olacağını belirttiklerini ortaya çıkarmışıı. Bu bakımdan değerlendirildiğinde genelde eğitim denetiminin özelde ise ders denetiminin örgütsel bir zorunluluk olduğu ifade edilebilir.

Araştırma sonucuna göre ders denetimlerinin gerekliliğini, bireysel açıdan ve örgütsel açıdan gereklilik şeklinde iki ana başlık altında toplamanın mümkün olduğu görülmüştür. Ders denetimini, bireysel açıdan gerekli kılan nedenler genel olarak; öğretmenlerin performanslarının belirlenebilmesi, öğretmenlerin geliştirilebilmeleri, motivasyonlarını ve öz güvenlerinin sağlanabilmesi ve öğretim programlarının uygulanma düzeyinin tespitidir. Öğretmenler, okul idarecileri ve müfettişler ders denetimlerinin özellikle öğretmen performansının ortaya konulması açısından gerekli olduğunu belirtmektedirler. Ders denetiminin öğretmen performansını ortaya çıkarma işlevinin önemli olduğu bulgusu literatür bilgileri ile örtüşmektedir. Köklü (1996) eğitim sisteminin amaçlarının gerçekleştirilmesi doğrultusunda etkili bir çalışmanın yapılıp yapılmadığının denetim aracılı̆̆ıyla belirleneceği ve gerekli düzenlemelerin yapılmasına denetim yoluyla ışık tutulabileceğini ifade etmektedir. Öğretmenlerin birçok yönden geliştirilmesi, eksikliklerinin giderilmesi, mesleki gelişimlerinin sağlanması ders denetiminin işlevleri arasındadır. (Gündüz, 2012). Öğretmenlerin kendilerine yüklenen misyonu gerçekleştirip gerçekleştiremediklerini, süreç içerisinde varsa hedeflerden sapmaları ve zorlukları belirleyerek, bunların 
giderilmesini sağlamak ancak bilimsel ölçme yöntemleri ve denetim ile mümkündür (Altun, 2014). Ders denetimi öğretmenlere yol göstererek hata yapma olasılığını en alt düzeye indirmeye çalışır. Böylece öğretmenlerin moral, motivasyon ve performanslarını artırmayı temel bir amaç olarak gözetir (Aslanargun \& Göksoy, 2013).

Araştırma sonuçlarına göre ders denetimini, örgütsel açıdan gerekli kılan nedenler genel olarak; çalışan ve çalışmayan personelin ayrımını yapabilmek, kurumlarda etkin yönetimi sağlayabilmek, eğitim öğretim çalışmalarındaki eksiklik ve yanlışlıkları tespit ederek giderebilmek, eğitsel ve öğretimsel amaçlara ulaşma düzeyini ortaya koymak şeklinde ortaya çıkmışır. Katılımcılar tarafından çalışan öğretmenle çalışmayan öğretmenin ayırt edilmesi önemsenmekte ve bunu ortaya koymada denetimin yapılması bir gereklilik olarak vurgulanmaktadır. Eğitsel faaliyetlerin niteliği hakkında durum tespiti ve değerlendirmenin yapılması bir zorunluluk olarak görülmektedir. Bu zorunluluğun sağlanabilmesi ve etkin yönetim için denetimin gerekli olduğu ifade edilmektedir. Eğitimde denetimin örgütsel amaçlara ulaşma derecesini kontrol etme, eğitim iş görenlerini geliştirme gibi amaçları olmakla birlikte, okuldaki en önemli kaynak olan insan kaynağının etkili yönetilip yönetilmediğini ortaya çıkarması da arzulanmaktadır (Demirtaş, 2010).

Öğretmenlerden okul müdürlerine ve denetçilere kadar birçok eğitim paydaşınca göz ardı edildiği ortaya konulan denetimle ilgili konuların en az idari ve politik konular kadar ön plana çıkarılması bireysel ve örgütsel açıdan bir gerekliliktir (Hsıeh \& Shen, 1998). Denetimin, örgütsel amaçlara ulaşma düzeyini kontrol etmesi ve örgütsel gelişimi sağlaması rolü bu gerekliliği ifade etmektedir. Bu bakımdan teftiş bir zorunluluk, ayrıca önleyici ve düzeltici eylemler sağlamanın ilk koşuludur (Bursalıoğlu, 2012).

\section{Uzmanlık Gerektiren Bir Alan Olarak Ders Denetimi}

Araştırma sonucunda öğretmenlerin, okul idarecilerinin ve müfettişlerin ders denetimini uzmanlık gerektiren bir alan olarak gördükleri ortaya çıkmıştır. Araştırma sonuçlarına göre ders denetiminin uzmanlık gerektiren bir alan olması denetim elemanının alana (programa ve uygulanmasına, planlamalara, yöntem ve tekniklere) hâkim, insan ilişkileri ve iletişim konusunda yeteri beceriye sahip olması gerekliliğinden, denetimi yapacak kişilerin öğretmenlik meslek bilgisine (alan bilgisi, pedagojik formasyon ve genel kültür) sahip olmaları zorunluluğundan ve denetimin kendi içerisinde belli ilke ve kuralları olan bir disiplin olmasından kaynaklanmaktadır. Denetimi gerçekleştirecek kişinin bu disiplinin ilke ve kurallarının da farkında olması gerekmektedir. Araştırmanın bu sonucu ile ilgili olarak Taymaz (2005) müfettişlerin görevlerini yerine getirebilmesi için teknik, insancıl ve karar yeterliklerine sahip olmaları gerektiğini ifade etmektedir. Aslanargun ve Tarku (2014) araştırmaları sonucunda müfettişlerin yapıcı, uyarııı ve yol gösterici olmaları noktasında yeterli olmaları gerektiği sonucuna ulaşmışlardır. Müfettişler, denetlenen için rol model olmakla birlikte kamuyu korumada en üst düzeyde görev yapan ve denetlenenlerin yeterlik standartlarına erişmesini sağlayan bir pozisyondadır (Gündüz \& Göker, 2014).Denetim elemanının; denetlenecek dersin programı ve kazanımları, öğretim yöntem teknikleri, sınıf yönetimi, öğrenci davranışları ve gelişimi konularında bilgi sahibi, denetime dair teorik ve uygulama noktasında yeterliliğe sahip olması gibi birçok alanda yeterliliği bulunması gerekmektedir. Bu yeterlilik alanlarının her birinin uzmanlık gerektirdiği göz önünde bulundurulduğunda ders denetimlerinin uzmanlık gerektiren bir alan olduğu görülmektedir.

\section{Okul Müdürlerinin Ders Denetimi Konusundaki Uzmanlıkları}

Öğretmen, okul idarecileri ve müfettişler, okul müdürlerinin ders denetimi konusunda uzman olmadıklarını düşünmektedirler. Okul müdürlerinin kendilerini ders denetimi konusunda yetersiz olarak değerlendirmeleri ise manidar bir sonuç olarak ortaya çıkmıştır. Okul müdürlerinin ders denetimi konusunda uzman olmamalarında en çok dile getirilen gerekçeler, okul müdürlerinin denetim formasyonuna sahip olmamaları veya bu konudaki yetersizlikleri, değerlendirmede objektif olamamaları ve öğretim programlarına hâkim olmamalarıdır. Öğretmenlerin, okul idarecilerinin ve müfettişlerin bu konuda büyük ölçüde aynı görüşte oldukları görülmektedir. Araştırmanın bu bulgusuyla ilgili olarak Aslanargun ve Göksoy (2013) tarafından yapılan araştırmada öğretmenlerin okul müdürlerinin ders 
denetimi hususunda objektiflik kaygısı taşıdıkları ifade edilmiştir. Acar (2009), araştırmasında okul müdürlerinin denetimi, daha çok rehberlik, yardım ve destek olarak algılamalarına rağmen, uygulamada bunu öğretmenlere yansıtamadıklarının görüldüğünü, öğretmenlerin okul müdürleri tarafından yapılan denetimlerin amacına uygun yapılmadığını düşündüklerini ve denetimi kontrol edici ve eleştirici olarak algıladıklarını ortaya çıkarmıştır. Sonuç olarak denetimi yapacak denetim elemanının denetim formasyonuna sahip, denetleyeceği derslerin tamamının programlarına hâkim ve değerlendirmede objektif olması gerektiği; ancak okul müdürlerinin genel anlamda bu yeterliklere sahip olmadıkları ifade edilmektedir.

\section{Ders Denetimlerinin Okul Müdürleri Tarafından Yapılmasının Olumlu Yönleri}

Araştırma sonucunda, okul müdürlerinin kurumu, öğretmenleri, velileri, çevreyi daha iyi tanımaları ve eğitim öğretim sürecinin tamamına hâkim olmaları, ders denetimlerinin okul müdürleri tarafından yapılmasının olumlu yönleri olarak ortaya çıkmıştır. Öğretmenler, okul idarecileri ve müfettişler, ders denetimlerinin okul müdürlerince yapılmasının olumlu yönlerini genel olarak okul müdürlerinin öğretmenlerini daha iyi tanımaları ve öğretmeni süreç içerisinde izleyebilme imkânına sahip olmalarıyla açıklamışlardır. Altun (2014) tarafından yapılan araştırma sonucunda öğretmenlerin denetimi ağırlıklı olarak okul müdürü, okul müdür yardımcısı ve zümre başkanı tarafından yapılması yönünde görüş bildirdikleri ortaya konmuştur. Aslanargun ve Göksoy (2013) tarafından yapılan araştırmada müdür değerlendirmesinin, süreç değerlendirmesi ve performansın daha yakından izlenmesine imkân tanıması açısından öğretmenler tarafından daha yakın durulan bir denetim tercihi olduğu ifade edilmektedir.

\section{Ders Denetimlerinin Okul Müdürleri Tarafindan Yapılmasının Olumsuz Yönleri}

Araştırma sonucuna göre ders denetimlerinin okul müdürleri tarafından yapılmasının olumsuz yönleri ile ilgili olarak özellikle okul müdürlerinin objektif olamamaları, okul müdürlerinin denetim formasyonu, öğretim programları ve pedagojik formasyon alanlarındaki yetersizlikleri, denetimi yapan okul müdürünün denetlediği öğretmenle sürekli aynı ortamı paylaşmasından dolayı denetimin gerçekliğinin azalması, denetim sonucunda kurumda çatışma çıkması, denetimin kurum içinden biri tarafından yapılmasından dolayı denetimin ağırlığının azalması, denetimi yapan okul müdürünün karar vermede baskı altında kalması, denetimin sonucunu etkileyebilmek için öğretmenlerin idareye yakınlaşmaya çalışmaları, denetim sonucunda kurumda hizipleşmelerin olması durumları vurgulanmıştır. Denetim sonucunda müdür-öğretmen, öğretmen-öğretmen arasında çatışma çıkması durumu önemli bir olumsuz yön olarak değerlendirilmektedir.

Okul idarecilerinin, ders denetimlerinin okul müdürleri tarafından yapılmasının olumsuz yönlerine ilişkin görüşlerinin öğretmen ve müfettişlerin olumsuzluk bildiren görüşlerinden daha fazla olduğu da manidar bir sonuç olarak ortaya çıkmıştır. Denetimin okul müdürleri tarafından yapılmasının olumsuz yönlerine ilişkin olarak okul idarecilerinin öğretmen ve müfettişlerden daha fazla görüş bildirmeleri denetimin kim ya da kimler tarafından ve nasıl yapılması gerektiği noktasında tartışmaya ihtiyaç bulunduğunu ortaya koymaktadır. Ders denetimlerinin okul müdürleri tarafından yapılmasında olumlu yön olarak ifade edilen birkaç duruma karşın olumsuz yön olarak ifade edilen durumların çok daha fazla olduğu görülmektedir.

Ders denetimlerinin okul müdürleri tarafından yapılmasının olumlu ve olumsuz yönlerine ilişkin olarak yapılan farklı araştırma sonuçlarına bakıldığında bu araştırmanın sonuçları ile örtüşen ve farklı olan sonuçlara rastlanmıştır. Demir ve Tok (2015) yaptıkları araştırmada okul müdürlerinin çevre şartlarını ve öğretmenleri daha iyi tanıyabilecekleri öngörüsünün ders denetimlerinin okul müdürlerince yapılmasının olumlu yönü olduğunu ifade etmişlerdir. Aslanargun ve Göksoy (2013) tarafından yapılan araştırmada okul müdürleri tarafından yapılan ders denetimlerinin objektiflik kaygısı taşıdığı ifade edilmekle birlikte denetimlerin sonuç eksenli ve genel olarak evrak temelli yapılmasını engelleyebileceği de belirtilmiştir. Yılmaz (2009) tarafından yapılan araştırma sonucunda okul müdürlerinin denetleyecekleri öğretmenleri denetmenlerden daha iyi tanıması, öğretmenlerin iyi yönlerini, geliştirilmesi gereken yönlerini bilmeleri, öğretmenlerin yaptıkları her türlü etkinlikten haberdar 
olmaları, öğretmenlerin sadece ders saatlerindeki değil ders dışı zamanlardaki etkinliklerinden haberdar olmaları, okul müdürlerince yapılacak denetimler sayesinde denetimlere uzun aralar verilmesinin engellenecek olması olumlu yön olarak ortaya çıkmıştır. Yapılan araştırma sonuçlarına bakıldı̆̆ında ders denetimlerinin okul müdürlerince yapılmasının olumlu ve olumsuz yönlerinin bu araştırma sonuçları ile örtüştüğü görülmektedir.

\section{Ders Denetimlerinin Müfettişler Tarafından Yapılmasının Olumlu Yönleri}

Araştırmada ders denetimlerinin müfettişler tarafından yapılması öğretmen ve okul idarecilerince daha istendik bir durum olarak algılandığı ortaya çıkmışır. Öğretmen ve okul idarecileri ders denetimlerinin müfettişler tarafından yapılmasının olumlu yönleri ile ilgili olarak özellikle müfettişlerin denetim ve değerlendirmede objektif ve denetim alanında uzman olduklarıı, müfettişlerin alana ve programa hâkim olduklarını, tecrübeli ve denetim işinde profesyonel olduklarını, etkili denetim yaptıklarını vurgulamışlardır. Akşit (2006) tarafından yapılan araştırma sonucunda müfettişler tarafından yapılan denetimin objektif olması bakımından birkaç yılda bir, müdürler tarafından ise her yıl yapılması gerektiği sonucuna ulaşılmıştır. Demir ve Tok (2015) tarafından yapılan araştırmada öğretmenlerin müfettiş denetimlerini objektif gördükleri ve müfettişlerin uzmanlıklarına inandıkları ortaya çıkmıştır. Demirtaş ve Akarsu (2016) tarafından yapılan araştırmada ders denetimlerinin müfettişler tarafından yapılmasının olumlu yönleri öğretmenin daha hazırıklı davranması, işini ciddiye alması, müfettişlerin daha tarafsız, adil ve eşit bir teftiş yapmaları, aynı branştan maarif müfettişlerinin teftiş yapmasının kaliteyi artırması, maarif müfettişlerinin denetim işinin uzmanı olmaları, öğretmene rehberlik yapmaları, yeniliklerin ve değişiklerin öğretmene hızlı ve doğru bir şekilde ulaştırııması şeklinde ortaya çıkmıştır.

\section{Ders Denetimlerinin Müfettişler Tarafından Yapılmasının Olumsuz Yönleri}

$\mathrm{Bu}$ araştırmanın bir diğer sonucuna göre ders denetimlerinin müfettişler tarafından yapılmasının olumsuz yönleri; sistem kaynaklı, öğretmen kaynaklı ve müfettiş kaynaklı olumsuzluklar şeklinde sınıflandırılmışır. Sistem kaynaklı olumsuzluklar, denetim elemanının kontrolünde olmayan olumsuz yönlerdir. Denetim süresinin kısa olması, müfettişlerin eğitim öğretim sürecinin tamamına hâkim olamamaları, müfettişlerin okulu, öğretmeni ve çevreyi yeterince tanımamaları, müfettiş kavramının öğretmen ve öğrencide oluşturduğu kaygı, müfettişlerin branşları dışındaki derslerin denetimini yapmak durumunda kalmaları sistem kaynaklı olumsuzluklar olarak ortaya çıkmıştır. Müfettişler hakkındaki ön yargılar ve öğretmenlerin öğrencilerinde yarattığı müfettiş fobisi de öğretmen kaynaklı olumsuzluk olarak ortaya çıkmıştır. Araştırma sonucunda ders denetiminin yapılmasında müfettiş kaynaklı olumsuzluklarla ilgili olarak okul idarecileri ve müfettişler ile öğretmenlerin büyük bir kısmına göre herhangi bir olumsuzluğun söz konusu olmadığı görülmüştür. Araştırmanın bu sonucu ile ilgili olarak Demirtaş ve Akarsu (2016) tarafından yapılan araştırma sonucunda ders denetimlerinin müfettişler tarafından yapılmasının olumsuz yönleri olarak; müfettişlerin öğretmenle yılda bir kez bir araya gelmeleri, müfettişlerin sadece evrak kontrolünü yapmaları, müfettişlerin taraflı davranmaları, aynı branştan müfettişlerinin teftiş yapmaması, müfettişlerinin kendilerini tatmin için teftiş yapmaları, müfettişlerin tutum ve davranışlarının yanlış olması, derste üçüncü bir kişinin varlığının, öğretmeni ve öğrencileri rahatsı etmesi, strese sokması, maarif müfettişlerinin önyargılı olmaları gibi alt kategoriler ortaya çıkarılmıştır. Bu alt kategorilere bakıldığında olumsuzluk durumlarının sistem kaynaklı, öğretmen kaynaklı ve müfettiş kaynaklı olumsuzluklar olduğu ve bu iki araştırma sonucunun örtüştüğü görülmektedir. Yapılan farklı araştırmalar irdelendiğinde ders denetimlerinin müfettişler tarafından yapılmasının olumlu ve olumsuz yönleri ile ilgili olarak elde edilen araştırma bulgularıyla bu araştırmanın bulgularının örtüştüğü görülmektedir. Ders denetimlerinin müfettişler tarafından yapılmasının olumlu ve olumsuz yönlerinin olduğu ve bu olumsuz yönlerin büyük oranda müfettiş dışı etkenlerden kaynaklandığı görülmektedir.

\section{Ders Denetimlerinin Kim ya da Kimler Tarafından Yapılması Gerektiği}

Araştırmanın bir diğer sonucuna göre katılımcılar ders denetimlerinin kim ya da kimler tarafından yapıımasının uygun olacağına ilişkin olarak en fazla müfettişlerin ders denetimi yapmaları gerektiğini 
belirtmişlerdir. Öğretmenlik deneyimlerinin bulunması, denetim işinde uzman olmaları, alana hâkim olmaları, dışarıdan birinin yaptığı denetimin işe ciddiyet katması, müfettiş denetiminin öğretmenin dikkatini arttırması ve müfettiş denetimiyle öğretmenin kontrol altına alınabileceği gerekçelerinden ötürü ders denetimlerinin müfettişler tarafından yapılması gerektiğini belirtilmiştir. Rosenfeld, Giacalone ve Riordan da (1995) yaptıkları araştırmada; öğretmenlerin, en etkin katılım sürecinin müfettişlerle gerçekleşebileceğine inandıkları sonucuna ulaşmışlardır. Ders denetimlerinin okul müdürleri tarafından yapılması gerektiğini ifade eden katılımcılar bunun gerekçesini müfettişlerin kurumlara çok sık gidememeleri, okul müdürlerinin sürecin tamamına hâkim oluşları ve öğretmeni daha iyi tanımalarıyla açıklamışlardır.

Bu araştırmanın sonucuna göre ders denetiminin müfettişler tarafından yapılması gerektiği görüşü ön plana çıkmıştır. Müfettiş seçeneğinden sonra sırasıyla okul müdürü, müfettiş-okul müdürü, müfettiş-okul müdürü-veli, öğretmenler, özel kuruluşlar tarafından yapılması gerektiği görüşlerinin olduğu tespit edilmiştir. Ders denetimlerinin kim ya da kimler tarafından yapılması gerektiğine ilişkin olarak yapılan araştırma sonuçlarına bakıldığında farklı sonuçların ortaya çıktığı görülmektedir. Demir ve Tok (2015) yaptıkları araştırma sonucunda öğretmenlerin, daha objektif olacakları ve alanlarında uzman oldukları için maarif müfettişlerini; çevreyi, ortamın şartlarını ve kendilerini daha iyi tanıyabilecekleri öngörüsü ile de müdürlerin denetim yapmasını uygun gördüklerini ortaya koymuştur. Gündüz, Aslan ve Bozkuş (2015) tarafından yapılan araştırma sonucunda okul yöneticilerinin öğretmeni denetleme, ona rehberlik etme, onun mesleki gelişimini sağlama görevlerini yerine getirmeleri gerektiği sonucuna ulaşıımıştır. Okutan'ın (2015) yaptığı araştırma sonucunda öğretmen ve okul müdürlerinin, ders denetimlerinin okul müdürleri tarafından yapılmasına olumlu baktıkları, maarif müfettişlerinin ise ders denetimlerinin okul müdürlerince yapılmasının yanlış olduğu görüşünde oldukları ortaya konulmuştur. Demirtaş ve Akarsu (2016) tarafından yapılan araştırma sonucuna göre öğretmenlerin maarif müfettişleri tarafından yapılan teftiş uygulamalarını olumlu bulmadıkları, bunun yerine bazı kaygılara rağmen müdür teftişine olumlu baktıkları ortaya çıkmışır. Aslanargun ve Göksoy (2013) tarafından yapılan araştırma sonucunda objektiflik kaygııı taşımalarına karşın mevcut öğretmenlerin müdür değerlendirmesine daha yakın durduğu, süreç değerlendirmesi ve performansın daha yakından izlenmesi açılarından müdür değerlendirmesinin tercih edildiğini ortaya koymuştur. Yıldız, Akbaşlı ve Üredi (2015) tarafından yapılan araştırma sonucunda ilkokul ve ortaokul öğretmenlerinin, kurum müdürlerinin yaptığı rehberlik ve denetim uygulamalarının etkililiğine ve gerekliliğine ilişkin olumlu yönde görüş bildirdikleri bulunmuştur. Altun (2014) tarafından yapılan araştırma sonucunda öğretmen denetimini kimin yapması gerektiğine ilişkin öncelikli tercihlerinin okul müdürü, okul müdür yardımcısı, zümre başkanı ve müfettiş olduğu sonucu ortaya çıkmıştır. Yılmaz (2009) tarafından yapılan araştırma sonucunda ders denetimlerinin okul müdürleri tarafından yapılmasının uygun olacağı ifade edilmiştir. Topçu'nun (2010)çalışmasına göre gerek yöneticiler gerekse öğretmenlerin çoğu, sınıf içi etkinliklerin ve öğretmenlerin değerlendirilmesinin en iyi okul yöneticileri tarafından yapabileceğini düşündükleri ortaya çıkarılmıştır. Alay (2006) tarafından yapılan araştırmada ise öğretmenlerin klasik değerlendirme sistemini yetersiz buldukları, sadece okul müdürleri ve müfettişler tarafından değerlendirilmelerini olumsuz olarak değerlendirdikleri sonucu ortaya çıkmışır. Başol ve Kaya (2009) tarafından yapılan araştırma sonucunda ise öğretmenlerin okul müdürü tarafından değerlendirilmeyi müfettiş tarafından değerlendirilmeye tercih ettikleri görülmüştür. Akbaba ve Memişoğlu (2008) tarafından yapılan araştırmada ise öğretmenlerin çoğunluğunun okul müdürlerinin denetimde daha aktif rol almaları gerektiğini, bazı öğretmenlerin de okul müdürlerinin subjektif olma durumlarının söz konusu olabileceğinden müdür denetimine şüpheyle yaklaştıklarını ortaya koymuştur. Farklı araştırma sonuçlarından anlaşılacağı üzere ders denetimlerinin kim ya da kimler tarafından yapılması gerektiğine ilişkin farklı görüşler olmakla birlikte bu görüşlerin müfettiş ve/veya okul müdürleri üzerinde yoğunlaştığı görülmektedir.

\section{Öneriler}

1. Bu araştırma sonucunda öğretmenlerin, okul idarecilerinin ve müfettişlerin ders denetiminin gerekli olduğuna ilişkin ortak bir inançlarının bulunduğu, ders denetimlerinin yapılmasının bireysel ve 
örgütsel açıdan bir gereklilik olduğu sonucu ortaya çıkmıştır. Bu bakımdan eğitim öğretim hizmetlerinin niteliğinin tespiti ve bu niteliğin arttırılabilmesi için ders denetimlerinin yapılmasına devam edilmelidir.

2. Araştırma sonucunda ders denetiminin uzmanlık gerektiren bir alan olduğu ortaya çıkmışır. Denetim işinin uzmanlık gerektiren bir alan olması denetimde görev alacak olanların uzmanlığını gerektirmektedir. Ders denetimleri konusunda gerekli olan uzmanlı̆ı elde edebilmeleri için denetim elemanlarının hizmet içi eğitim faaliyetleri ve kurslarla yetiştirilmeleri ve geliştirilmeleri sağlanabilir.

3. Araştırmada ders denetimlerinin daha çok müfettişler tarafından yapılması yönünde sonuç ortaya çıkmıştır. Denetime muhatap olan okul idarecileri ve öğretmenlerin bu görüşlerinden hareketle mevcut uygulamaya göre okul idarecileri tarafından yapılan ders denetimlerinde müfettişlerin etkin olarak görev almaları sağlanabilir, bu yolla hem denetim alanının uzmanı olan müfettişlerin bu uzmanlıklarından faydalanılarak denetim alanında yetişmiş insan kaynağının daha etkin kullanılması sağlanabilir hem de bu yolla denetim sürecinin niteliği arttırılabilir. Ayrıca okul müdürlerinin de müfettişlerle birlikte denetim sürecinde aktif rol üstlenerek yer almaları sağlanabilir.

4. Araştırma sonucuna göre öğretmenler, okul idarecileri ve müfettişlerin, ders denetimi konusunda okul müdürlerinin uzman olmadıklarını düşündükleri ortaya çıkmıştır. Okul idarecilerinin, ders denetimi konusunda okul müdürlerinin yetersiz olduğu yönündeki inançları manidar bir sonuç olarak değerlendirilebilir. Okul müdürlerinin ders denetimi konusunda uzman olmamalarının sebepleri ise genel olarak okul müdürlerinin denetim formasyonuna sahip olmamaları ya da bu konudaki yetersizlikleri, değerlendirmede objektif olmamaları ya da olamamaları ve öğretim programlarına yeterince hâkim olamamaları gerekçelerine dayandırılmıştır. Ayrıca araştırma sonucunda ders denetimlerinin okul müdürleri tarafından yapılmasının olumlu yönleri olarak; okul müdürlerinin kurumunu, personelini ve okul çevresini daha iyi tanıdıkları, okuldaki eğitim sürecinin başında olmalarından dolayı bu sürecin tamamı hakkında bilgi sahibi olmaları şeklinde ortaya çıkmışır. Bu olumsuz ve olumlu durumlar göz önünde bulundurulduğunda ders denetimlerinin sadece okul müdürlerine bırakılması yerine okul müdürlerinin aktif olarak görev aldığı ve müfettişler tarafından gerçekleştirilecek olan dış denetim yoluyla ders denetimlerinin yapılması sağlanabilir. Bu yolla ders denetimlerinin okul müdürleri tarafından yapılmasının olumsuz yönleri ortadan kaldırılabilir ve olumlu yönleri denetim sürecine yansitılabilir.

5. Hâlihazırda ders denetimleri okul müdürleri eliyle yürütülmektedir. Bu uygulamaya devam edildiği süre içerisinde, yapılacak olan okul müdürü seçimlerinde aday yöneticilerin denetim yeterliklerinin de dikkate alınması sağlanabilir.

6. Araştırma sonucunda ders denetimlerinin gerek yıl içerisinde yapılma sayısının gerekse ders denetimi saatinin yetersiz olduğu ortaya çıkmışır. Ders denetimi periyotlarının arttıılarak ve ders denetimi sürelerinin uzatılarak (sürece yayılarak) müfettişlerin eğitim öğretim sürecine daha fazla hâkim olmaları böylece müfettişlerin öğretmeni, okulu ve okul çevresini daha fazla tanımaları sağlanabilir.

7. Araştırma sonucunda ders denetimlerinin ağırlıklı olarak müfettişler tarafından yapılması gerektiği yönünde bir sonuç ortaya çıkmıştır. Bunu sırasıyla müfettiş ve okul müdürünün birlikte denetimi, okul müdürü denetimi, öğretmen denetimi, veli denetimi, bağımsız kuruluşlarca yapılacak denetim gibi farklı görüşler izlemiştir. Ders denetimlerinin kim ya da kimler tarafından yapılması gerektiğine ilişkin olarak Millî Eğitim Bakanlı̆ıınca paydaşların tamamından alınacak görüşler doğrultusunda yeni bir denetim uygulaması ortaya konulabilir, akabinde pilot uygulama yapılabilir, pilot uygulamanın sonuçları değerlendirilebilir.

8. Bu çalışmada ders denetimine ilişkin öğretmen, okul idarecileri ve müfettişlerin görüşleri incelenmiştir. Yapılacak farklı araştırmalarda öğrenci, veli ve diğer eğitim yöneticilerinin görüşleri incelenebilir.

9. Bu çalışmada ders denetimi sorunsalı öğretmen, okul idarecisi ve müfettiş görüşlerine dayalı olarak nitel araştırma yaklaşımı ile incelenmiştir. Yapılacak farklı bir çalışmada konu ile ilgili yapılan araştırmalar metaanaliz yöntemiyle incelenebilir. 


\section{References}

Acar, U. (2009). Yönetici ve öğretmenlere göre Türk ve Alman (Krv Eyaleti) okul müdürlerinin ders denetimi uygulaması, (Yayınlanmamış Yüksek Lisans Tezi), Ankara Üniversitesi, Ankara.

Acheson, K. \&Gall, M. D. (2011). Clinical supervision and teacher development. Hoboken, NJ: John Wiley $\&$ Sons.

Ağaoğlu, E. (2010). Okul yöneticilerinin denetim ve değerlendirme rolü. Servet Özdemir (Ed.). Türk eğitim sistemi ve okul yönetimi içinde (s. 193-207). Ankara: Pegem Yayınevi.

Akbaba Altun, S. \& Memişoğlu, S. P. (2008). Performans değerlendirmesine ilişkin öğretmen, yönetici ve müfettiş görüşleri. Kuram ve Uygulamada Eğitim Yönetimi Dergisi, Kış (2008), 7-24.

Akşit, F. (2006). Performans değerlendirmeye ilişkin öğretmen görüşleri (Bigadiç ilköğretim öğretmenleri örneği). Sosyal Bilimler Araştırmaları Dergisi,2,6-101.

Alay, G. (2006). ilköğretim ve ortaöğretim kurumlarında görev yapan öğretmenlerin performans değerlendirme sistemine ilişkin görüşleri. (Yayınlanmış Yüksek Lisans Tezi), Gazi Üniversitesi, Ankara.

Altun, B. (2014). Denetime eleştirel yaklaşım: öğretmen denetimi nasıl olmalı?.(Yayınlanmış Yüksek Lisans Tezi), Adnan Menderes Üniversitesi, Aydın.

Aslanargun, E. \& Göksoy, S. (2013). Öğretmen denetimini kim yapmalıdır?.Uşak Üniversitesi Sosyal Bilimler Dergisi, Özel Sayı, 98-121.

Aslanargun, E. \& Tarku, E. (2014). Öğretmenlerin mesleki denetim ve rehberlik konusunda müfettişlerden beklentileri. Kuram ve Uygulamada Eğitim Yönetimi Dergisi, 20(3), 281-306.

Aydın, ì. (2005). Öğretimde denetim durum saptama değerlendirme ve geliştirme. Ankara: Pegem Akademi.

Aydın, M. (2000). Çağdaş eğitim denetimi. Ankara: Hatipoğlu Yayınevi.

Badiali, B.,Firth, G. \&Pajak, E. (1997). Teaching supervision. handbook of research in supervision. New York: MacMillan Publishers.

Başaran, İ. E. (1996). Eğitim yönetimi (4. Baskı). Ankara: Yargıcı Matbaası.

Başol, G. \& Kaya, I. (2009). Theprimaryteachers' opinions on their performance evaluation by school administrators [Full Text]. The First International Congress of Educational Research Online Full TextBook, Retrieved from http://oc.eab.org.tr/egtconf/pdfkitap/pdf/545.pdf, Çanakkale 18 Mart University, Çanakkale, Turkey.

Buluç, B. (1997). Türk eğitim sisteminde teftiş ve denetim alt sisteminin gelişim süreci. Bilgi Çağında Eğitim Dergisi, 27-30.

Bursalıoğlu, Z. (2012), Okul yönetiminde yeni yapı ve davranış. Ankara: Pegem Akademi.

Chamberlin, C. R. (2000). TESL Degree candidates' perceptions of trust in supervisors. TESOL Quarterly, 34(4), 653-673.

Demir, M. \& Tok, T. N. (2015). Lisansüstü öğrencilerinin görüşlerine göre eğitim denetimi. VII. Uluslararası Eğitim Denetimi Kongresi, Dokuz Eylül Üniversitesi, İzmir.

Demirtaş, Z. (2010). Öğretmeni hizmet içinde yetiştirmenin bir aracı olarak denetim. Elektronik Sosyal Bilimler Dergisi, 9(31), 41-52.

Demirtaş, H. \& Akarsu, M. (2016). Öğretmen teftişini müfettiş yerine okul müdürünün yapmasına ilişkin öğretmen görüşleri. Inönü Üniversitesi Eğitim Fakültesi Dergisi, 17(2), 69-93.

Erdem, A. R. \& Eroğul, M. G. (2012 a). Sınıf öğretmenlerinin görüşlerine göre eğitim müfettişlerinin ders denetim yeterlikleri. Sosyal Bilimler Enstitüsü Dergisi, Sayı 12, 97-109. 
Erdem, A. R. \& Eroğul, M. G. (2012b). Sınıf öğretmenlerinin görüşlerine göre ders denetiminde eğitim müfettişlerinin öğretmene ilişkin tutumları. Pamukkale Üniversitesi Eğitim Fakültesi Dergisi, Sayı 31 (Ocak 2012/I), 13-26.

Glanz, J.,Shulman, V. \& Sullivan, S. (2007). Impact of instructionalsupervision on studentachievement: can we make the connection? Chicago: PaperPresented at theAnnual Conference of the American Educational Research Association: 1-28.

Glickman, C. D. (1990). Supervision of instruction. Massachusetts: Allynand Bacon Inc.

Glickman, C. D., Gordon, S. P. \&Ross-Gordon, J. (2004), Supervision and instructional leadership: a developmental approach. Boston: Allynand Bacon.

Gökçe, F. (1994). Eğitim denetiminin amaç ve ilkeleri. Hacettepe Üniversitesi Eğitim Fakültesi Dergisi, 10, 73-78.

Gündüz, Y. (2012).Eğitim örgütlerinde denetimin gerekliliği: kuramsal bir çalışma. Dumlupınar Üniversitesi Sosyal Bilimler Dergisi, 34,1-6.

Gündüz, Y. \& Göker, S. D. (2014). Dünya ölçeğinde eğitim denetmenlerinin iş tanımlarındaki çelişkiler ve rol çatışmaları. Abant İzzet Baysal Üniversitesi Eğitim Fakültesi Dergisi, 14(2), 155-174.

Gündüz, Y., Aslan, H. \& Bozkuş, K. (2015). Öğretmenlerin denetim ve rehberlik dışı bırakılmalarının olası sonuçları. VII. Uluslararası Eğitim Denetimi Kongresi, Dokuz Eylül Üniversitesi, İzmir.

Hsieh, C. L. \&Shen, J. (1998). Teachers', principals' and superintendents' conceptions of leadership. School Leadership \& Management, 18(1), 107-121.

Köklü, M. (1996). Etkili denetim. Eğitim Yönetimi Dergisi, 2(2), 259-268.

Marzano, R. J. \&Frontier, T. \& Livingston, D. (2011). Effective supervision-supportingthe art and science of teaching. USA: ASCD Premium Member Book.

MEB İlköğretim Müfettişleri Kurulu Yönetmeliği. (1990).

MEB İlköğretim Müfettişleri Başkanlıkları Yönetmeliği. T.C.Resmî Gazete, 23785, 13 Ağustos 1999.

MEB Eğitim Müfettişleri Başkanlıkları Yönetmeliği. T.C.Resmî Gazete, 27974, 24 Haziran 2011.

MEB Rehberlik ve Denetim Başkanlığı İle Maarif Müfettişleri Başkanlıkları Yönetmeliği. T.C. Resmî Gazete, 29009, 24 Mayıs2014.

Memduhoğlu, H. B. (2012). Öğretmen, yönetici, denetmen ve öğretim üyelerinin görüşlerine göre Türkiye'de eğitim denetimi sorunsalı. Kuram ve Uygulamada Eğitim Bilimleri Dergisi, 12(1), 135-156.

Memişoğlu, S. P. (2012).Okulda yönetim süreçleri. Niyazi Can (Ed.).Kuram ve uygulamada eğitim yönetimi içinde (s. 128-154). Ankara: Pegem Yayınevi.

Millî Eğitim Bakanlığının Teşkilat ve Görevleri Hakkında Kanun Hükmünde Kararname. T.C.Resmî Gazete, 28054, 14 Eylül2011.

Millî Eğitim Bakanlığının Teşkilat ve Görevleri Hakkında Kanun Hükmünde Kararname İle Bazı Kanun ve Kanun Hükmünde Kararnamelerde Değişiklik Yapılmasına Dair Kanun. T.C.Resmî Gazete, 29913, 9 Aralık 2016.

Okutan, M. (2015). Öğretmen, okul müdürü ve maarif müfettişlerinin görüşlerine göre eğitimdeki denetim uygulamalarının değerlendirilmesi. VII. Uluslararası Eğitim Denetimi Kongresi, Dokuz Eylül Üniversitesi, İzmir.

Özbaş, M. (2002). ilköğretim okulu müdürlerinin sınıf içi etkinliklerin denetiminde yapmaları gereken ve yapmakta oldukları işler konusunda müdür ve öğretmen görüşleri. (Yayımlanmış Yüksek Lisans Tezi), Hacettepe Üniversitesi, Ankara. 
Rizzo, J. F. (2004). Teachers' supervisiors' perceptions of current and ideal supervision and evaluation practices. Doctoral Dissertation. Graduate School of the University of Massachusetts, School of Education, Amherst. http://scholarworks.umass.edu/dissertations/AAI3118327/.

Rosenfeld, P. R.,Giacalone, R. A. \&Riordan, C. A. (1995). Impression management in organizations: Theory, measurement, andpractice. New York: Routledge.

Selçuk, Z. (2000). Okul deneyimi ve uygulama (öğretmen ve öğrenci davranışlarının gözlenmesi). Ankara: Nobel.

Sergiovanni, T. J. \&Starratt, R. J. (2002). Supervision: A redefinition. New York: McGraw-Hill.

Taymaz, H. (2005).Eğitim sisteminde teftiş. Ankara: Pegem Yayıncılık.

Topçu, í. (2010). Devlet ve özel ilköğretim okullarında yöneticilerin öğretimin denetimi görevlerini yerine getirme biçimleri. Cumhuriyet Üniversitesi Sosyal Bilimler Dergisi, 34(2), 31-39.

Wiles, J. \& Bondi, J. (2000). Supervision: a guide to practice. (5th edt.) USA: Prentice-Hall, Inc.

Yıldırım, A. \& Şimşek, H. (2011), Sosyal bilimlerde nitel araştırma yöntemleri. Ankara: Seçkin Yayıncılık.

Yıldız, B., Akbaşlı, S. \& Üredi, L. (2015). Kurum müdürlerinin yaptığı rehberlik ve denetim uygulamalarına ilişkin öğretmen görüşlerinin değerlendirilmesi. VII. Uluslararası Eğitim Denetimi Kongresi, Dokuz Eylül Üniversitesi, İzmir.

Yılmaz, K. (2009). Okul müdürlerinin denetim görevi. Inönü Üniversitesi Eğitim Fakültesi Dergisi, 10 (1), 19-35. 